\title{
25. CALCAREOUS NANNOFOSSILS FROM THE NORTH ATLANTIC (LEG 48)
}

\author{
Carla Müller, Geologisch-Paläontologisches Institut der Universität, Frankfurt am Main, Germany
}

\section{INTRODUCTION}

During IPOD Leg 48 (Bay of Biscay and Rockall Plateau) nine holes were drilled at eight sites. Sites 399 to 402 are located in the Bay of Biscay and Sites 403 to 406 on the margins of the Rockall Plateau. Calcareous nannofossils are generally abundant in the sediments recovered in both areas.

Age determinations for the Lower Cretaceous sediments (only in the Bay of Biscay) are based on the nannoplankton zonation proposed by Thierstein $(1971,1973)$; for the Upper Cretaceous, that proposed by Roth (1973), which combined zones proposed by Bukry and Bramlette (1970), Cepek and Hay (1969), and Martini (1969), was used. Martini's (1971) nannoplankton zonation is used for Tertiary and Quaternary sediments (Table 1). Paleogene nannoplankton zones can be recognized without difficulty, whereas, for the Neogene it becomes complicated or impossible because of the scarcity or absence of most of the index fossils in regions of lower water temperatures. For the Pliocene section it was necessary to use combined zones. Water temperatures began to decline in late Eocene time, continuing to do so during the Neogene.

Location of the sites (Figure 1) at different latitudes and in different water depths allows some ecological interpretations.

The results of this investigation are based on about 1500 samples, only several of which were studied with the stereoscan.

Fossil lists are given for all sites; only selected samples are listed.

\section{NANNOFOSSIL ZONES IDENTIFIED AT LEG 48 SITES HOLE 400A}

(lat $47^{\circ} 22.90^{\prime} \mathrm{N}$; long $09^{\circ} 11.90^{\prime} \mathrm{W}$; water depth: $4399 \mathrm{~m}$ )

Hole 400A was drilled at the foot of the Meriadzek Escarpment near the ocean-continent boundary on the northern continental margin of the Bay of Biscay. It was washed down to 74.5 meters sub-bottom after the upper part of the Pleistocene (Zones NN 21 and NN 20) was recovered from the nearby located Site 399.

The Pseudoemiliania lacunosa Zone (NN 19) of the lower Pleistocene is present at Hole 400A from Core 1 to Core 3, Section 2, 100 to $101 \mathrm{~cm}$ ( 74.5 to $95.0 \mathrm{~m}$ )(Table 2). The assemblage of this zone is marked by the abundance of Discolithina japonica and Pontosphaera pacifica. The Pliocene/Pleistocene boundary is marked by the extinction of Cyclococcolithus macintyrei in Core 3; discoasters are missing or extremely rare in upper Pliocene rocks. Some layers of the upper Pliocene sequence are distinguished by high content of terrigenous material and reworked Cretaceous species, indicating that the first ice-rafted material occurred in late Pliocene time, approximately in the upper- most part of the Discoaster surculus Zone (NN 16) at about 3 to 2.7 m.y. B.P.

Subdivision of the Pliocene section is difficult even though the sediments are rich in well-preserved nannofossils, because index fossils are missing or are scarce; the last discoasters are present within the $D$. surculus Zone (NN 16), the base of which is determined in Core 8, Section 1 .

Lower Pliocene sediments occur from Core 8, Section 2 to Core 15 , Section 5 , where it is necessary to use combined zones. The stratigraphic interval of the $D$. asymmetricus/ Reticulofenestra pseudoumbilica Zone (NN 14/NN 15) is present from Core 8, Section 2 to Core 13, Section 4.R. pseudoumbilica specimens are smaller in the upper part of the nannoplankton Zone NN 15, where a short overlapping of $R$. pseudoumbilica and $P$. lacunosa can be observed.

The Ceratolithus tricorniculatus/Ceratolithus rugosus Zone (NN 12/NN 13) was recovered from Core 13, Section 5 to Core 15 , Section 5 ; the sediments are rich in wellpreserved nannoplankton. Slightly warmer water temperatures are inferred for the lowermost part of Zone NN 12 by the increasing number of discoasters and $C$. tricorniculatus. The Discoaster quinqueramus Zone (NN 11) of the upper Miocene (Table 3) is determined from Core 16, Section 1 to Core 21 (218.0 to $274.0 \mathrm{~m}$ sub-bottom). D. quinqueramus is restricted to a few samples. Fluctuations of water temperature can be assumed from the variable abundance of discoasters therein. Nannofossils are abundant but, in several layers, are broken and etched. The assemblage is of low diversity. Core 22 to Core 26 probably belong to the stratigraphic interval of the Discoaster hamatus/Discoaster calcaris Zone (NN 9/NN 10). One specimen of Catinaster coalitus was found in Core 27, Section 1, indicating the $C$. coalitus Zone (NN 8) of the middle Miocene. Cores 29 and 30 belong to the Discoaster kugleri Zone (NN 7), with $D$. kugleri, Discoaster exilis, and the large variety of Coccolithus pelagicus $(=C$. miopelagicus $)$. The $D$. exilis Zone (NN 6) is present in Cores 31 and 32 where the species is abundant. The Sphenolithus heteromorphus Zone (NN 5) is determined from Sample 34, CC to Sample 36, CC. Nannofossils are abundant, coccoliths are strongly etched and broken, discoasters are overgrown. The sequence from Core 37 , Section 1 , to Core 37 , Section 4 , probably belongs to the Helicosphaera ampliaperta Zone (NN 4) of the lower Miocene although $H$. ampliaperta was not observed. Sphenolithus belemnos was found from Sample 37, CC to Sample 38, CC indicating the Discoaster druggii/S. belemnos Zone (NN 2/NN 3); subdivision is not possible. The interval from Core 42 ( 435.5 to $473.5 \mathrm{~m}$ ) probably is lowermost Miocene in age.

The Oligocene/Miocene boundary is determined to lie between Core 42 and Core 43; Dictyococcites dictyodus does not occur above Core 43 (Table 4). 
TABLE 1

Nannofossil Zonation for Tertiary and Quaternary Stratigraphy

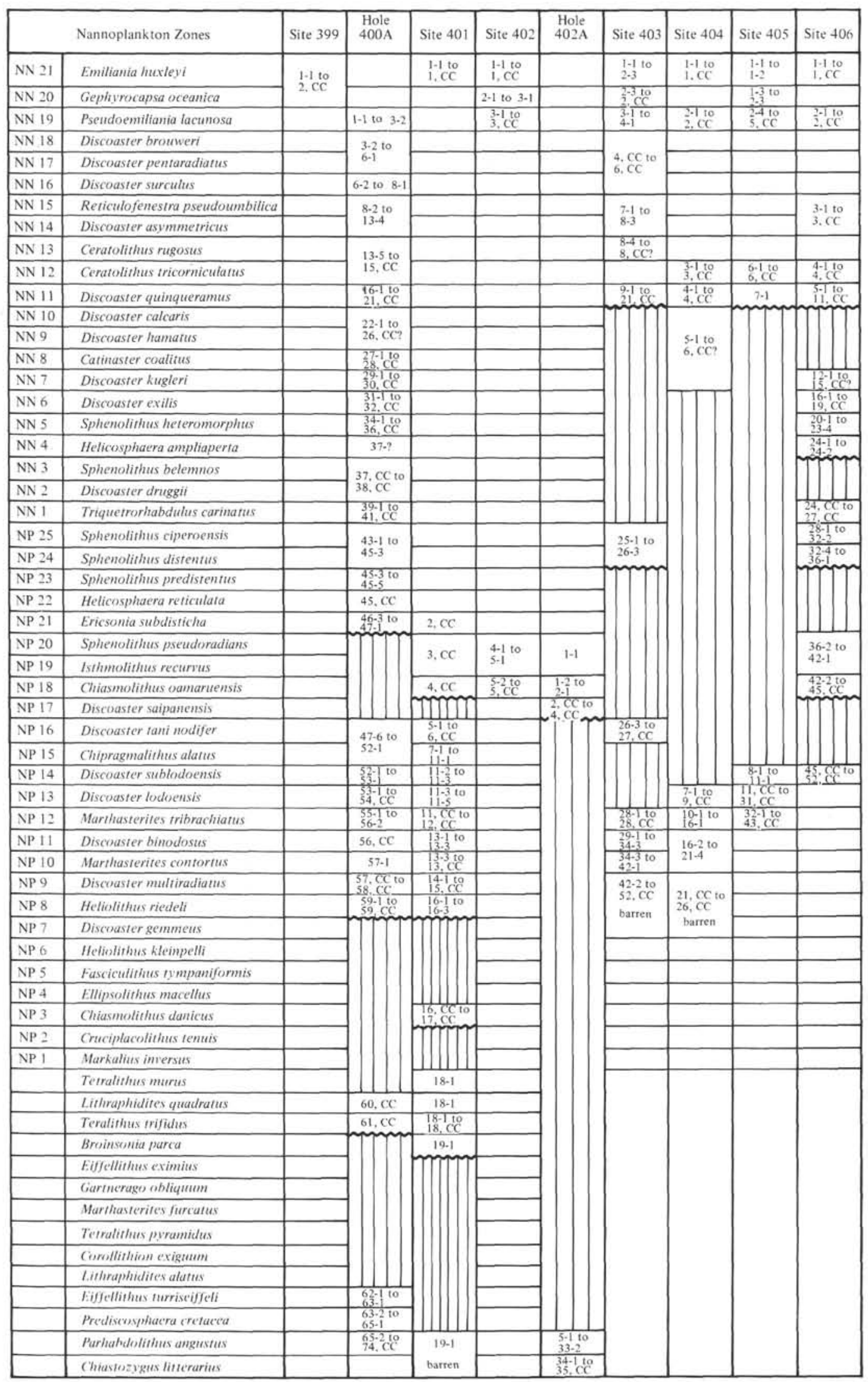




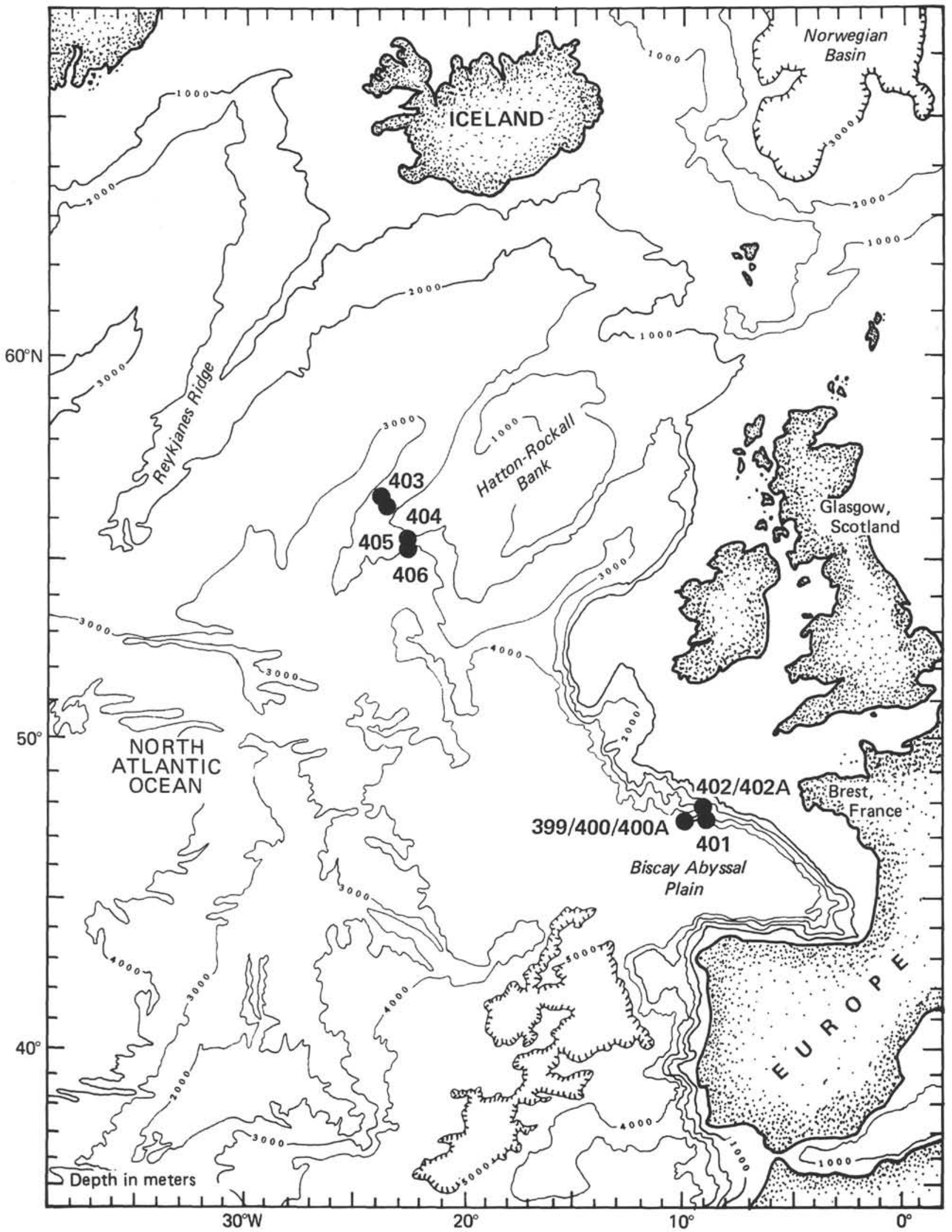

Figure 1. Location of sites drilled during Leg 48. 
TABLE 2

Calcareous Nannofossils From the Pliocene to Quaternary Sediments of Hole 400A

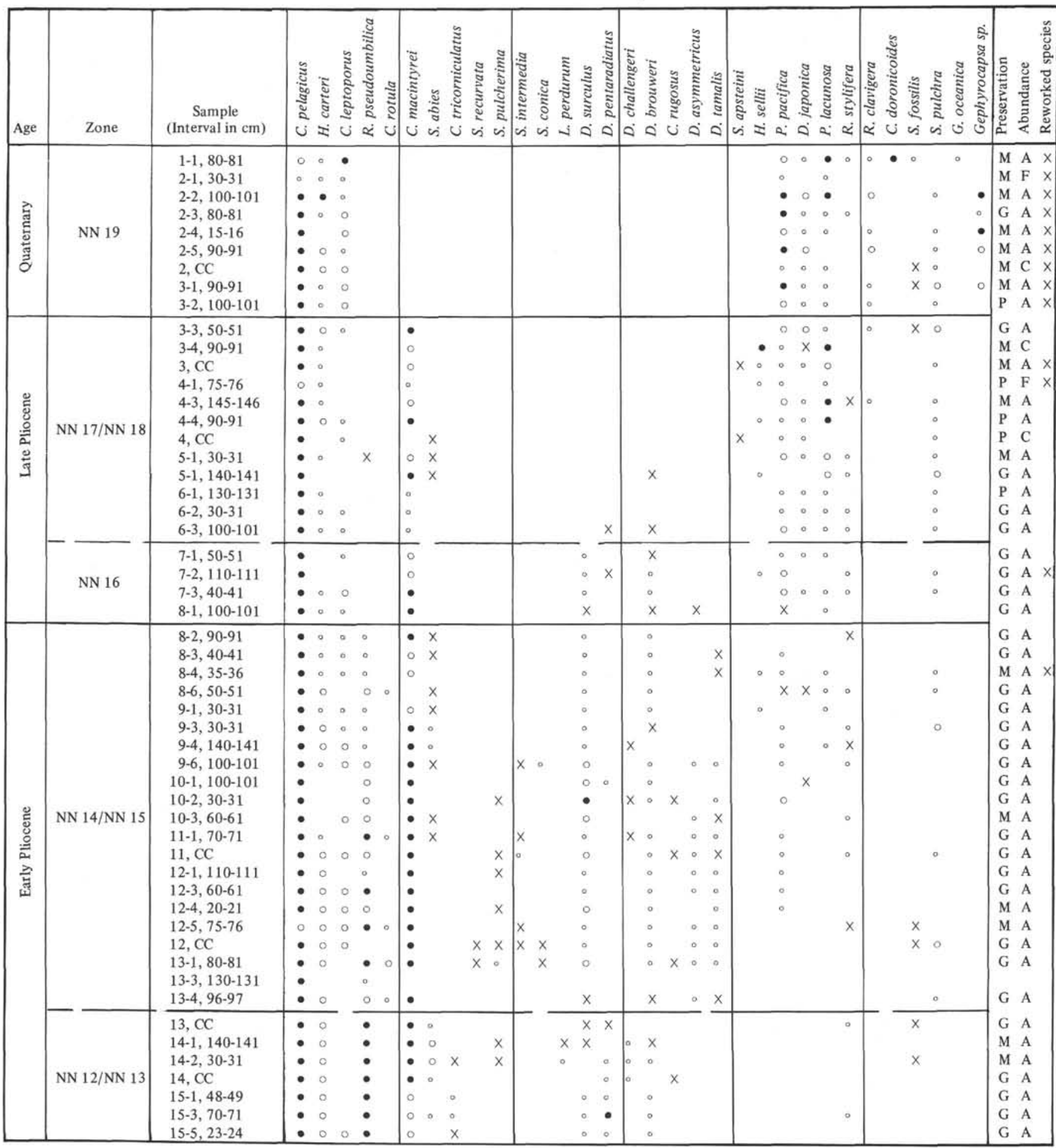

A complete Oligocene sequence was encountered from Core 43, Section 1 to Core 47, Section 1. Sediments are rich in poorly preserved nannofossils. Sample $43-1,1-2 \mathrm{~cm}$ to Sample 45-3, 56-57 cm belongs to the Sphenolithus distentus/Sphenolithicus ciperoensis Zone (NP 24/NP 25); Sample 45-3, 113-114 cm to Sample 45-5, 81-82 cm comprises the Sphenolithus predistentus Zone (NP 23). Lower
Oligocene is recorded in the interval from Sample 45, CC to Sample 47-1, 79-80 cm. Nannofossils are abundant, strongly etched and broken. Some specimens of Chiasmolithus oamaruensis were recovered from this unit.

Lower Oligocene sediments are underlain by the middle Eocene Discoaster tani nodifer Zone (NP 16) and the Chiphragmalithus alatus Zone (NP 15). Precise determination of 
TABLE 3

Calcareous Nannofossils From the Miocene Sediments of Hole 400A

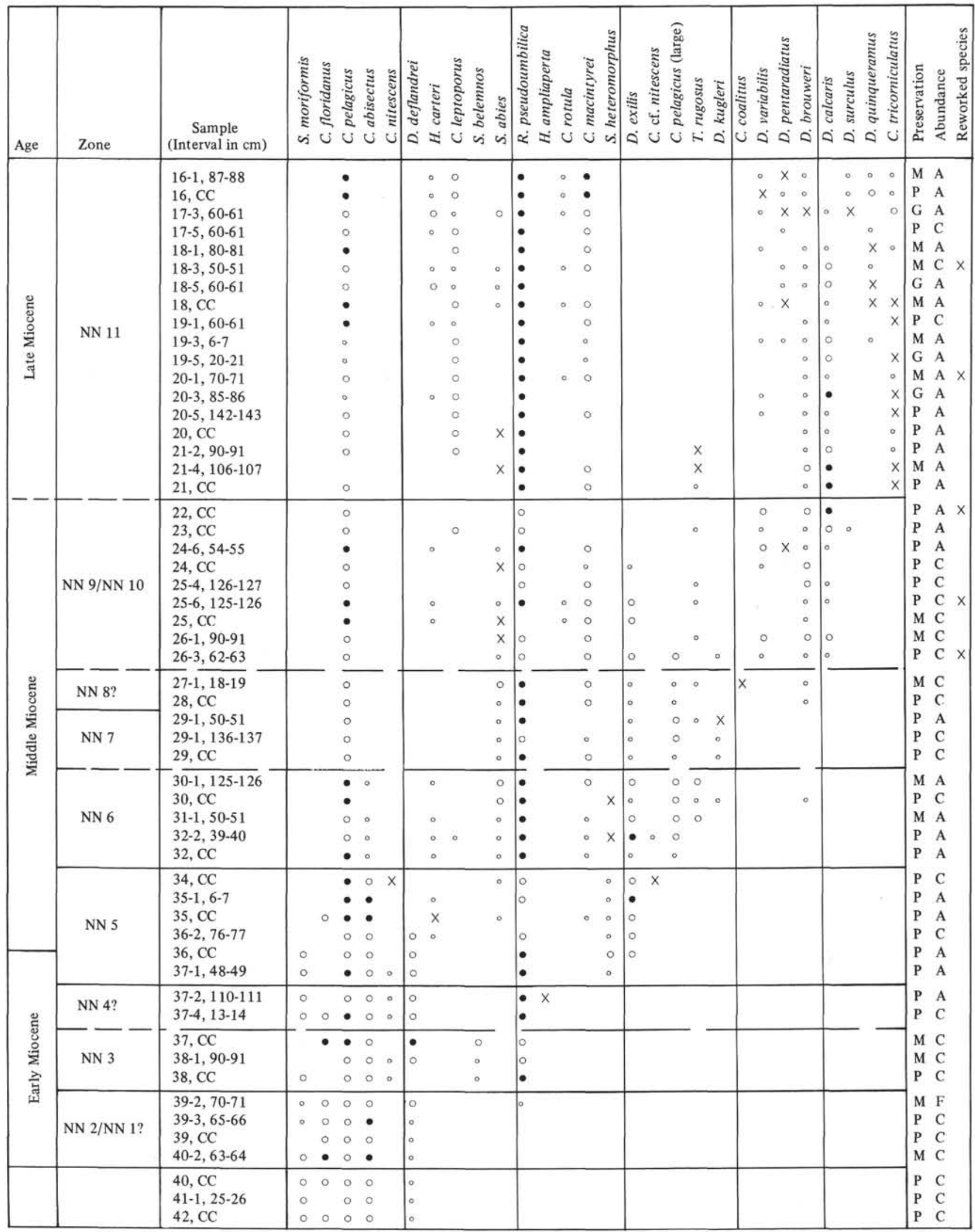

Note: Preservation: $\mathrm{P}=$ poor, $\mathrm{G}=$ good, $\mathrm{M}=$ moderate. Abundance: $\mathrm{T}=$ trace, $\mathrm{R}=\mathrm{rare}, \mathrm{C}=$ common, $\mathrm{A}=\mathrm{abundant.} \bullet=\mathrm{abundant,} \mathrm{o}=$ common, $\mathrm{o}=\mathrm{rare}$, $\mathrm{x}=$ trace. 
TABLE 4

Calcareous Nannofossils From the Paleogene Sediments of Hole 400A

\begin{tabular}{|c|c|c|c|c|c|c|c|c|c|c|c|c|c|c|c|c|c|c|}
\hline$A g e$ & Zone & $\begin{array}{c}\text { Sample } \\
\text { (Interval in cm) }\end{array}$ & 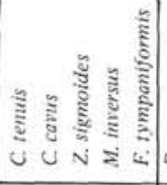 & 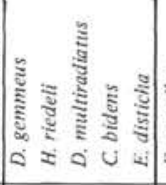 & 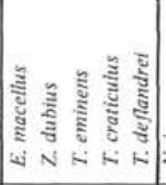 & 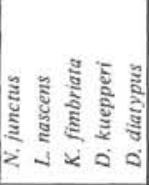 & 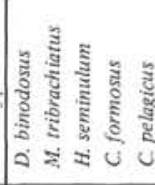 & & 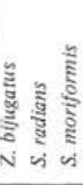 & $\begin{array}{l}0 \\
3 \\
3 \\
0 \\
0 \\
0 \\
0\end{array}$ & 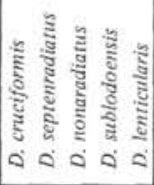 & 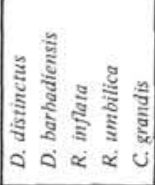 & 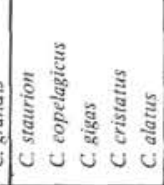 & 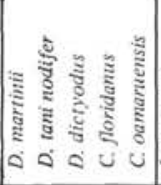 & 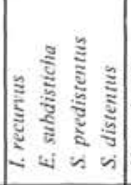 & 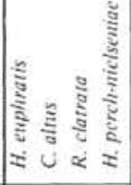 & & $\begin{array}{l} \\
\end{array}$ \\
\hline \multirow[t]{2}{*}{ 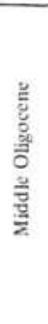 } & NP 24/NP 25 & $\begin{array}{l}43-1,81-81 \\
43-2,74-75 \\
43-4,68-69 \\
44-1,69-70 \\
44, C C \\
45-1,49-50 \\
45-2,45-46 \\
45-3,56-57\end{array}$ & & & & & $\begin{array}{l}\circ \\
\vdots \\
\vdots \\
\vdots \\
\circ\end{array}$ & $\begin{array}{l}0 \\
0 \\
0 \\
0 \\
0 \\
0\end{array}$ & $\begin{array}{l}0 \\
0 \\
0 \\
\vdots \\
\vdots \\
0\end{array}$ & & & & . & $\begin{array}{l}\therefore: \\
\therefore \\
\vdots \\
\vdots\end{array}$ & \begin{tabular}{rr|}
$x$ & $x$ \\
& $x$ \\
$\times$ & \\
\end{tabular} & 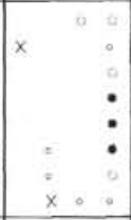 & $\begin{array}{l}\mathrm{P} \\
\mathrm{P} \\
\mathrm{P} \\
\mathrm{M} \\
\mathrm{M} \\
\mathrm{M} \\
\mathrm{M} \\
\mathrm{P}\end{array}$ & $\begin{array}{l}\mathrm{C} \\
\mathrm{C} \\
\mathrm{A} \\
\mathrm{A} \\
\mathrm{A} \\
\mathrm{A} \\
\mathrm{C} \\
\mathrm{C}\end{array}$ \\
\hline & NP 23 & $\begin{array}{l}45-3,113-114 \\
45-4,76-77 \\
45-5,81-81 \\
\end{array}$ & & & & & $\begin{array}{l}0 \\
\circ \\
\circ\end{array}$ & 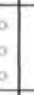 & $\begin{array}{l}0 \\
\vdots \\
\end{array}$ & & & & & $\begin{array}{ll} & 0 \\
0 & 0 \\
0 & 0 \\
0 & 0 \\
\end{array}$ & \begin{tabular}{l|l}
$x$ & $\times$ \\
$x$ & \\
\end{tabular} & \begin{tabular}{|c|}
0 \\
$\circ$ \\
0 \\
\end{tabular} & $\begin{array}{l}\mathrm{M} \\
\mathrm{P} \\
\mathrm{P}\end{array}$ & $\begin{array}{l}c \\
c \\
c\end{array}$ \\
\hline \multirow[b]{2}{*}{ 宩 } & NP 22 & $45, \mathrm{CC}$ & & & & & 웅 & 0 & $\circ$ & & &. & & . 0. & $0=$ & & $\mathrm{M}$ & A \\
\hline & NP 21 & $\begin{array}{l}46-3,105-106 \\
46-5,21-22 \\
47-1,79-80 \\
\end{array}$ & & & & & $\begin{array}{ll}0 & 0 \\
- & 0 \\
\circ & 0 \\
\end{array}$ & 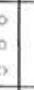 & $\begin{array}{l}0 \\
\vdots \\
\end{array}$ & & & $\therefore$ & & $\begin{array}{llll} & 0 & 0 & 0 \\
0 & 0 & & \\
0 & 0 & & \\
\end{array}$ & $\therefore:$ & & $\begin{array}{l}\mathrm{M} \\
\mathrm{M} \\
\mathrm{P}\end{array}$ & $\begin{array}{l}\mathrm{A} \\
\mathrm{A} \\
\mathrm{C}\end{array}$ \\
\hline \multirow{3}{*}{ 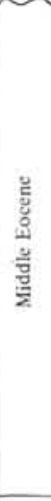 } & NP 16 & $\begin{array}{l}47-6,143-144 \\
47, C C \\
48-2,143-144 \\
49-1,60-61\end{array}$ & & & & " & $\begin{array}{l} \\
\vdots\end{array}$ & 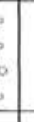 & $\therefore$ & & & $\begin{array}{lll} & \vdots & \vdots \\
0 & \vdots & 0 \\
0 & 0 & 0 \\
0 & 0 & 0 \\
\end{array}$ & 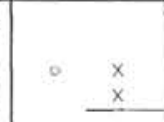 & $\therefore:$ & & & $\begin{array}{l}\mathrm{P} \\
\mathrm{M} \\
\mathrm{P} \\
\mathrm{M}\end{array}$ & $\begin{array}{l}\mathrm{F} \\
\mathrm{C} \\
\mathrm{C} \\
\mathrm{A}\end{array}$ \\
\hline & NP 15 & $\begin{array}{l}49-2,20-21 \\
49-3,80-81 \\
49-4,76-77 \\
50-4,112-113 \\
50, \mathrm{CC} \\
51-1,6-8 \\
51-2,103-104 \\
51-5,105-106 \\
51, \mathrm{CC} \\
52-1,9-10 \\
\end{array}$ & $x$ & & $\begin{array}{l}x \\
\\
x \\
x\end{array}$ & & 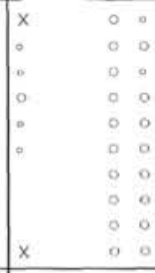 & $\begin{array}{l}0 \\
0 \\
0 \\
0 \\
0 \\
0 \\
0 \\
0 \\
\end{array}$ & $\begin{array}{r}\vdots \\
\vdots \\
\vdots \\
\times \\
\times \\
:\end{array}$ & $\begin{array}{l}\vdots \\
\vdots \\
\vdots \\
\vdots \\
\end{array}$ & $\begin{array}{cc}x & \\
x & 0 \\
0 & \\
0 & \\
0 & x \\
& \\
\end{array}$ & 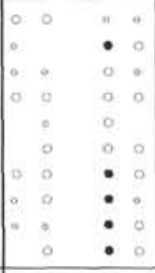 & 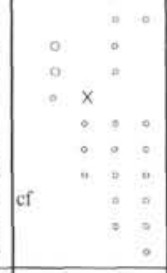 & . & & & $\begin{array}{l}\mathrm{P} \\
\mathrm{M} \\
\mathrm{P} \\
\mathrm{P} \\
\mathrm{P} \\
\mathrm{M} \\
\mathrm{M} \\
\mathrm{M} \\
\mathrm{M} \\
\mathrm{P}\end{array}$ & $\begin{array}{l}\text { A } \\
\text { C } \\
\text { C } \\
\text { C } \\
\text { C } \\
\text { C } \\
\text { C } \\
\text { C } \\
\text { A } \\
\text { C }\end{array}$ \\
\hline & NP 14 & $\begin{array}{l}52-1,108-109 \\
52-3,7-8 \\
52-5,47-48 \\
53-1,11-12\end{array}$ & $x$ & & $\dot{x}$ & & $\begin{array}{ll}\therefore & 0 \\
\vdots & 0 \\
\therefore & 0 \\
0 & 0\end{array}$ & & 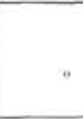 & $\begin{array}{ll}\circ & x \\
\therefore & x \\
* & \\
& \text { cf } \\
\end{array}$ & 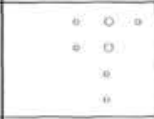 & \begin{tabular}{lllll}
0 & 0 & 0 & 0 & 0 \\
0 & 0 & $\vdots$ & 0 & 0 \\
\hdashline & $\vdots$ & 0 & 0 & 0 \\
0 & 0 & 0 & 0
\end{tabular} & $x$ & & & & $\begin{array}{l}\mathrm{M} \\
\mathrm{P} \\
\mathrm{P} \\
\mathrm{P}\end{array}$ & $\begin{array}{l}\mathrm{C} \\
\mathrm{C} \\
\mathrm{F} \\
\mathrm{F}\end{array}$ \\
\hline \multirow{3}{*}{ 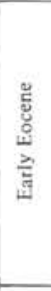 } & NP 13 & $\begin{array}{l}53, \mathrm{CC} \\
54-1,104-105 \\
54-2,121-122 \\
54-3,110-111 \\
54, \mathrm{CC} \\
\end{array}$ & $x$ & & $x$ & $\therefore$ & $\begin{array}{lll}0 & 0 & 0 \\
0 & x & \vdots \\
0 & 0 & \vdots \\
0 & & 0\end{array}$ & & $:$ & $\begin{array}{r}: \\
\vdots \\
0 \\
0 \\
0 \\
0\end{array}$ & : & 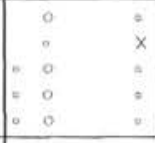 & & & & & $\begin{array}{l}\mathrm{P} \\
\mathrm{P} \\
\mathrm{P} \\
\mathrm{P} \\
\mathrm{P}\end{array}$ & $\begin{array}{l}\mathrm{C} \\
\mathrm{C} \\
\mathrm{F} \\
\mathrm{C} \\
\mathrm{C}\end{array}$ \\
\hline & NP 12 & $\begin{array}{l}55-1,103-104 \\
55, \mathrm{CC} \\
56-2,61-62 \\
\end{array}$ & $x$ & $:$ & 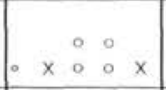 & $\because \vdots$ & : & & $\therefore$ & & & $\begin{array}{l}\circ \\
\circ \\
\end{array}$ & & & & & $\begin{array}{l}\mathrm{P} \\
\mathrm{P} \\
\mathrm{M}\end{array}$ & $\begin{array}{l}\mathrm{c} \\
\mathrm{C} \\
\mathrm{C}\end{array}$ \\
\hline & $\begin{array}{l}\text { NP11 } \\
\text { NP10 }\end{array}$ & $\begin{array}{l}56, \mathrm{CC} \\
57-1.148-149\end{array}$ & & $\begin{array}{ll} & 0 \\
0 & 0 \\
\end{array}$ & \begin{tabular}{lll|} 
& 0 & \\
$\circ$ & 0 & 0 \\
\end{tabular} & $\therefore$ & $\therefore$ & & . & & & $\circ$ & & & & & & $\begin{array}{l}c \\
c \\
c\end{array}$ \\
\hline \multirow[b]{2}{*}{ 递 } & NP 9 & $\begin{array}{l}57, \mathrm{CC} \\
58, \mathrm{CC}\end{array}$ & $\circ$ & \begin{tabular}{lll|}
0 & 0 & $x$ \\
0 & 0 &
\end{tabular} & $\begin{array}{rrr}0 & x & 0 \\
& 0 & 0 \\
\end{array}$ & 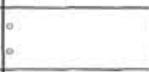 & & & & & & & & & & & & $\begin{array}{l}\mathrm{C} \\
\mathrm{A} \times\end{array}$ \\
\hline & NP 8 & $\begin{array}{l}59-1,25-26 \\
59-1,75-76 \\
59 . \mathrm{CC} \\
\end{array}$ & $\because \vdots: \quad=$ & $\begin{array}{lll}\because & 0 \\
\vdots & \vdots & 0 \\
0\end{array}$ & $\begin{array}{lll}0 & 0 & 0 \\
0 & 0 \\
0 & 0 \\
\end{array}$ & & & & & & & & & & & & $\begin{array}{l}\mathrm{M} \\
\mathrm{M} \\
\mathrm{G} \\
\end{array}$ & $\begin{array}{l}\mathrm{A} \\
\mathrm{A} \\
\mathrm{C}\end{array}$ \\
\hline
\end{tabular}

Note: Preservation: P=poor, $\mathrm{G}=$ good, $\mathrm{M}=$ moderate, Abundance: $\mathrm{T}=$ trace, $\mathrm{R}=\mathrm{rarc}, \mathrm{C}=$ common, $\mathrm{A}=$ abundant. $\bullet=$ abundant, $\mathrm{o}=$ common, $\mathrm{o}=\mathrm{rare}, \mathrm{X}=$ trace. 
the boundary between these two zones is not possible because Rhabdosphaera gladius is missing. Nannofossils are dissolved and/or diluted by the high amount of siliceous microfossils. In some samples discoasters are enriched by selective dissolution of the more fragile coccoliths. The hiatus between the lower Oligocene and the middle Eocene represents an interval of about $7 \mathrm{~m} . \mathrm{y}$. The Discoaster sublodoensis Zone (NP 14) is determined to lie between Core 52 , Section 1, and Core 53, Section 1. The D. lodoensis Zone (NP 13) is represented in the sediments from Core 53, Section 1, to Core 54, and the Marthasterites tribrachiatus Zone (NP 12)/Tribrachiatus orthostylus Zone (Bukry, 1973) in Core 55, Section 1, to Core 56, Section 2. Sample 56, CC belongs to the Discoaster binodosus Zone (NP 11) and Sample 57-1, 148-149 cm to the Marthasterites contortus Zone (NP 10).

Upper Paleocene sediments are recovered between Sample 57, CC and Sample 59, CC representing the Discoaster multiradiatus Zone (NP 9) and the Heliolithus riedeli Zone (NP 8). Well preserved nannofossils are abundant, with few reworked Cretaceous species.

The Cretaceous/Tertiary boundary lies between Core 59 and Core 60 (Table 5); the thickness of the Upper Cretaceous sequence is extremely reduced. The uppermost Maestrichtian (Tetralithus murus Zone) is not represented. The Lithraphidites quadratus Zone is recorded in Sample 60,
CC, and the Tetralithus trifidus Zone of the upper Campanian/lowermost Maestrichtian in Sample 61, CC. Nannofossils are abundant but severely broken. A hiatus of about $22 \mathrm{~m}$.y. lies between Cores 61 and 62 . The Eiffellithus turriseiffeli Zone of the upper Albian/lower Cenomanian is recognized from Core 62, Section 1, to Core 63, Section 1, and the Prediscosphaera cretacea Zone of the middle Albian from Core 63, Section 2, to Core 65, Section 1. The Parhabdolithus angustus Zone of the upper Aptian/ lower Albian is present from Core 65, Section 2, to Core 74. These sediments are rich in nannofossils and show more or less strong signs of dissolution. The Aptian/Albian boundary is determined at the first occurrence of Hayesites albiensis between Cores 68 and 69 .

\section{SITE 401}

(lat $47^{\circ} 25.65^{\prime} \mathrm{N}$; long $08^{\circ} 48.62^{\prime} \mathrm{W}$; water depth: $2495 \mathrm{~m}$ )

Hole 401 was located on top of a horst at the edge of the Meriadzek Terrace on the northern Biscay continental margin.

Pleistocene sediments (NN 21) were recovered in Core 1 (Table 6). The hole was washed down to 85.0 meters and core taken from this interval contained Oligocene sediments (NP 24). Lower Oligocene sediments of the Ericsonia subdisticha Zone (NP 21) are present in Core 2. Nannofossils are abundant, they are slightly etched and

TABLE 5

Calcareous Nannofossils From the Cretaceous Seciiments of Hole 400A

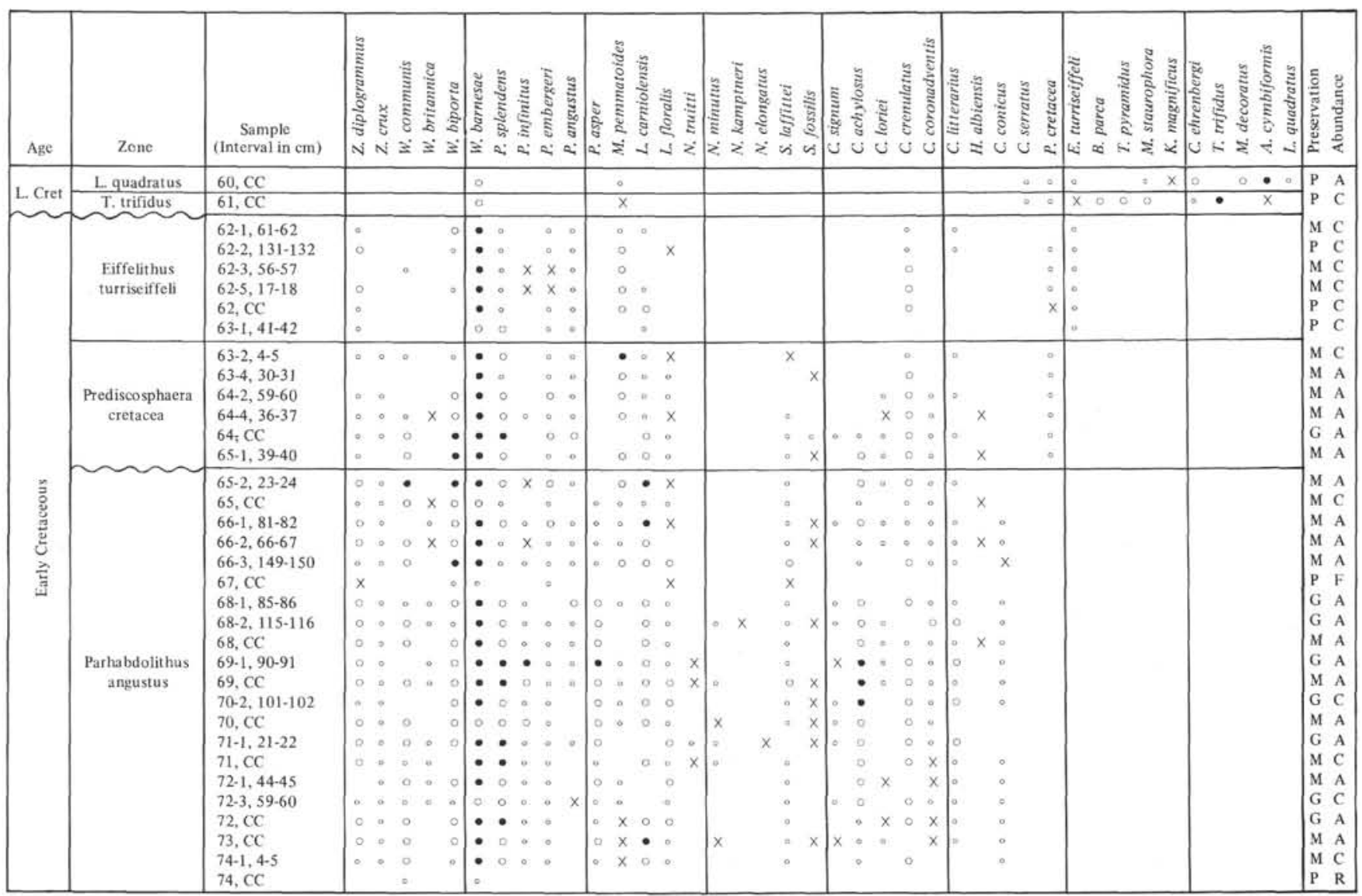


TABLE 6

Calcareous Nannofossils From the Middle Eocene to Quaternary Sediments of Site 401

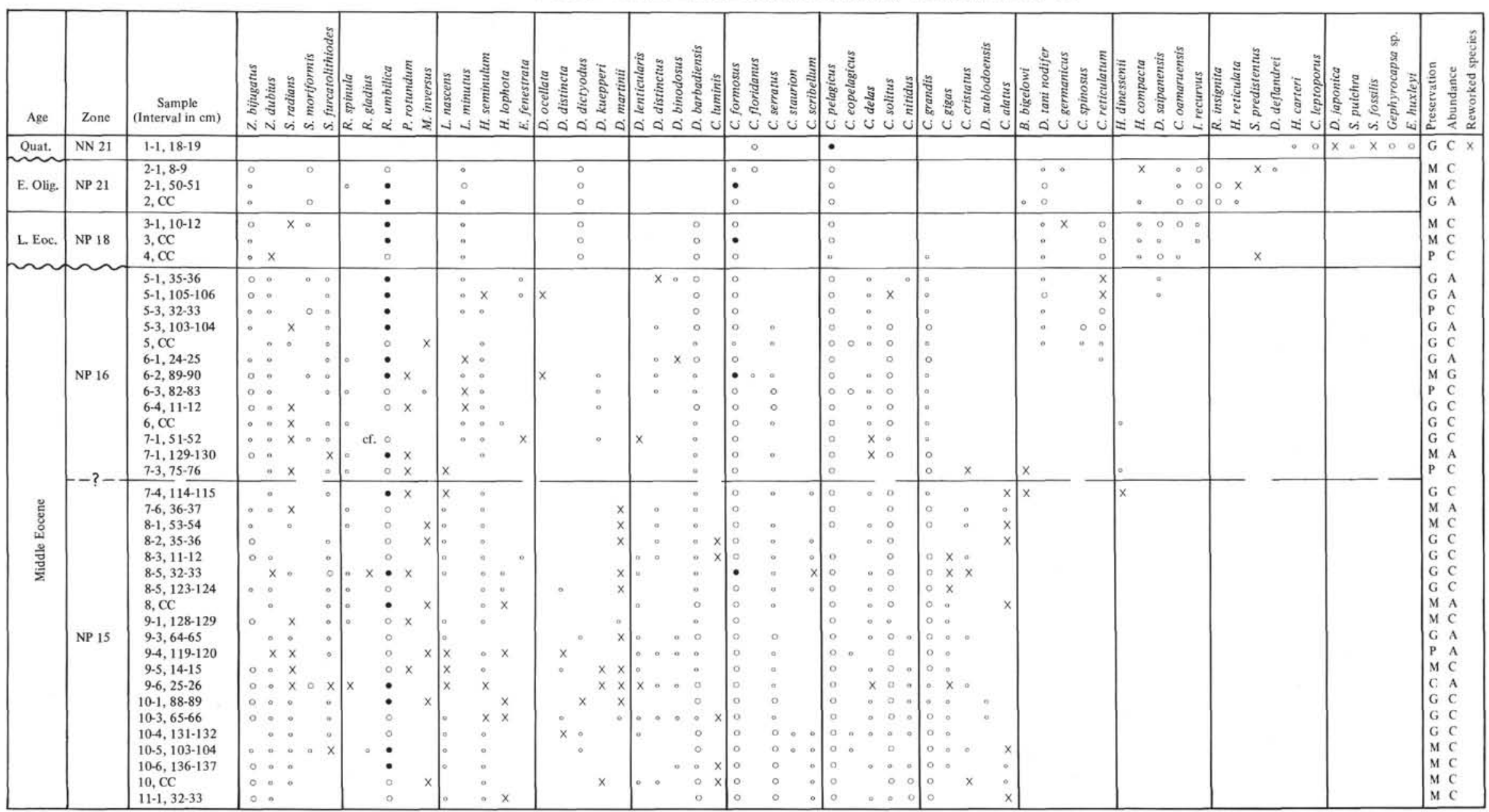

Note: Preservation: $\mathrm{P}=$ poor, $\mathrm{G}=$ good, $\mathrm{M}=$ moderate, Abundance: $\mathrm{T}=$ trace, $\mathrm{R}=$ rare, $\mathrm{C}=$ common, $\mathrm{A}=$ abundant. $\bullet=$ abundant, $\mathrm{o}=$ common, $\mathrm{v}=\mathrm{rarc}, \mathrm{X}=$ trace. 
broken. The Isthmolithus recurvus/Sphenolithus pseudoradians Zone (NP 19/NP 20) of the upper Eocene is recognized in Core $3(94.0$ to $103.0 \mathrm{~m})$. A hiatus which represents an interval of about $1 \mathrm{~m} . \mathrm{y}$., includes the $D$. saipanensis Zone (NP 17); it lies between Cores 4 and 5 .

The Discoaster tani nodifer Zone (NP 16) and Chiphagmalithus alatus Zone (NP 15) are present from Core 5 to Core 11 , Section $1(113.0$ to $170.50 \mathrm{~m})$; the sediments are rich in siliceous and calcareous microfossils. The boundary between the nannoplankton Zones NP 16 and NP 15 lies between Cores 6 and 7, Section 1; it is defined by the last occurrence of Rhabdosphaera gladius. The $D$. sublodoensis Zone (NP 14) is represented in Core 11, Sections 2 and 3 (Table 7). Core 11, Section 3, to Core 11, Section 5, belong to the D. lodoensis Zone (NP 13). The sediments are rich in nannofossils; coccoliths are etched and broken whereas the discoasters are overgrown.

The Marthasterites tribrachiatus Zone (NP 12) is present from Sample 11, CC to Sample 12, CC, the D. binodosus Zone (NP 11) from Core 13, Section 1, to Core 13, Section 3 , and the $M$. contortus Zone (NP 10) from Core 13, Section 3, to Sample 13, CC.

The Paleocene/Eocene boundary lies between Core 13 and Core 14. The upper Paleocene (D. multiradiatus Zone, NP 9 and Heliolithus riedeli Zone, NP 8) are present from Core 14 to Core 16, Section 3. The sediments contain well-preserved to slightly overgrown nannofossils. A hiatus, which represents an interval of about 4 m.y., lies between Core 16, Section 3, and Sample 16, CC. Cores 16 and 17 belong to the Chiasmolithus danicus Zone (NP 3) of the lower Paleocene. Another hiatus, which represents an interval of about $2 \mathrm{~m}$.y. exists between the Late Cretaceous of Core 18 and the early Paleocene. The Tetralithus murus Zone is present from Sample $18.1,11-12 \mathrm{~cm}$ to Sample $18.1,27-28 \mathrm{~cm}$ (Table 8 ). Sample $18-1,85-86 \mathrm{~cm}$ belongs to the Lithraphidites quadratus Zone. The sediments are rich in strongly etched and broken nannofossils. The Broinsonia parca/Tetralithus trifidus Zone of the upper Campanian/lowermost Maestrichtian is recognized in Sample 18-1, 120-121 cm to Sample 19.1, 98-99 cm. T. trifidus is missing, but Lucianorhabdus cayeuxii becomes very abundant in Sample 18.1, 120-121 cm to Sample 18, CC. Sample 19-1, 127-128 cm, just above the reddish limestone, contains a nannoplankton assemblage which consists mainly of nannoconids of late Aptian age. The hiatus between the late Aptian and the Campanian represents an interval of about $38 \mathrm{~m} . \mathrm{y}$. The limestones recovered at Site 401 from 247.5 to 341.0 meters are barren of nannofossils.

\section{HOLES 402/402A}

(lat $47^{\circ} 52.48^{\prime} \mathrm{N}$; long $08^{\circ} 50.44^{\prime} \mathrm{W}$; water depth: $2339.5 \mathrm{~m}$ )

Holes 402/402A are located on a spur of the northern continental margin of the Bay of Biscay north of the Meriazdek Escarpment. Pleistocene sediments (NN 21 to NN 19) were recovered in Core 1 to Core 3 of Site 402 and the sediments are rich in well-preserved nannofossils.

Pliocene and middle Miocene sediments are present in the washed down core, taken between 89.5 and 108.0 meters. The upper Eocene is present from Core 4 to Core 5 of Site 402. The Isthmolithus recurvus/Sphenolithus pseudoradians
Zone (NP 19/NP 20) is present from Sample 4, CC to Sample 5, Section 1, the Chiasmolithus oamaruensis Zone (NP 18) from Core 5, Section 2, to Sample 5, CC. The sediments have abundant siliceous microfossils and wellpreserved to slightly etched nannofossils.

The hole was washed down to 137.0 meters. The $I$. recurvus/S. pseudoradians Zone (NP 19/NP 20) occurs in Core 1 , Section 1 of Hole 402A (Table 9). Core 1, Section 2 , and Core 2, Section 1, belong to the $C$. oamaruensis Zone (NP 18) and Sample 2, CC to Sample 4, CC to the Discoaster saipanensis Zone (NP 17) of the upper Eocene. Upper Eocene sediments are separated from Cretaceous sediments by a hiatus representing an interval of at least 56 m.y. In Cores 5 and 6 (Table 10) few nannofossils are present; an exact age determination is not possible.

The Parhabdolithus angustus Zone of late Aptian to early Albian age occurs from Core 11 to Core 13. This sequence is distinguished by the occurrence of nannoconids, which are abundant in several layers, whereas other nannofossils are less so. The Chiastozygus litterarius Zone of the lower Aptian is present in Cores 34 and 35 (Table 11). Nannoconids are abundant, indicating marginal conditions.

\section{SITE 403}

(lat 56 $08.31^{\prime} \mathrm{N}$; long $23^{\circ} 17.64^{\prime} \mathrm{W}$; water depth: $2301 \mathrm{~m}$ )

Site 403 was drilled on the southwest margin of the Rockall Plateau. Pleistocene sediments (nannoplankton Zones NN21 to NN 19) were recovered in Core 1 to Core 4 (0 to $33.0 \mathrm{~m}$ ) (Table 12). The sediments are rich in well-preserved nannofossils; reworked species of Cretaceous age are present in several samples.

The Pliocene/Pleistocene boundary is determined by the extinction of Cyclococcolithus macintyrei between Sample 4-1, 98-99 cm and Sample 4, CC. The upper Pliocene (NN 16 to NN 18) is recognized from Sample 4, CC to Sample 6, CC. Subdivision of this sequence is not possible due to the scarcity or absence of discoasters, but the sediments are rich in slightly etched nannofossils. Slightly warmer water temperatures can be assumed for the Reticulofenestra pseudoumbilica Zone (NN 15) by the slight increase of discoasters and scyphospheres. The Ceratolithus rugosus Zone (NN 13) is represented in the lower part of Core 8. The $D$. quinqueramus Zone (NN 11) of the upper Miocene (Core 9 to Core 24$)$ is extremely thick ( 71.0 to $223.0 \mathrm{~m}$ ). Fluctuations of the water temperature are believed to have occurred during the deposition of this sequence on the basis of the variable abundance of discoasters and the differences in the degree of dissolution. C. tricorniculatus, $S$. abies and discoasters in general are rare due to low water temperatures.

A hiatus, which represents an interval of about $18 \mathrm{~m} . \mathrm{y}$., lies between Core 24 and 25 . The upper Miocene is underlain by middle/upper Oligocene sediments (NP 24/NP 25) in Core 25 to Core 26 , Section 3 . In turn, they are underlain by middle Eocene deposits (nannoplankton Zone NP 16) from 236.0 to 251.5 meters. This indicates a hiatus which includes an interval of about $3 \mathrm{~m} . \mathrm{y}$. Another hiatus, representing an interval of about $5 \mathrm{~m} . \mathrm{y}$., is present between the middle Eocene (NP 16) and the underlying lower Eocene (NP 12) in Core 28 (Table 13).

The sediments from Cores 29 to 42 (261.0 to $294.0 \mathrm{~m}$ ) are poor in nannofossils; they belong to the $M$. contortus $/ D$. 
TABLE 7

Calcareous Nannofossils From the Lower Paleocene to Middle Eocene Sediments of Site 401

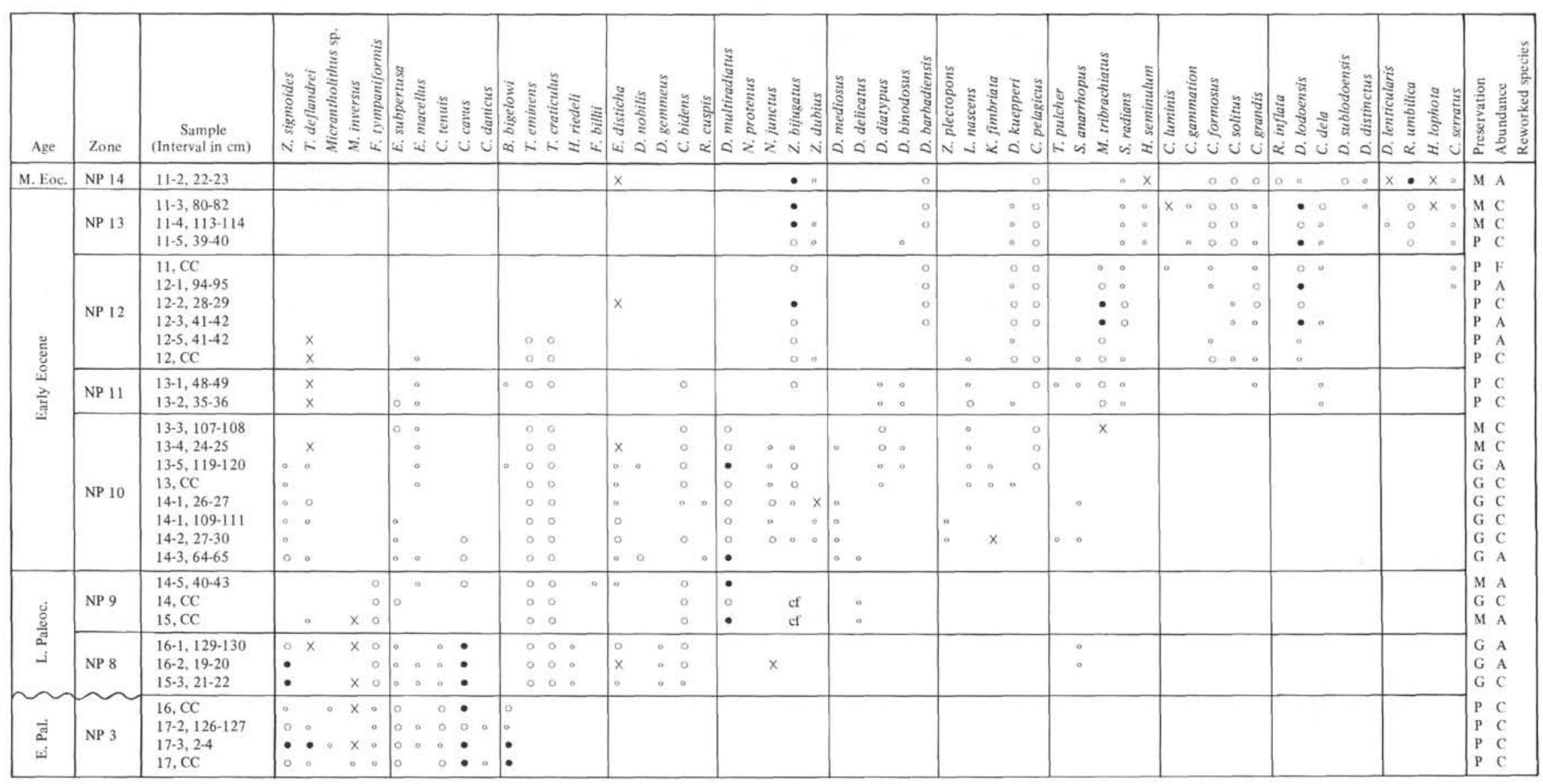

Note: Preservation: $P=$ poor, $G=$ good, $M$-moderate. Abundance: $T=t r a c e, ~ R=r a r e, C=$ common, $A=$ abundant. $\bullet=$ abundant, $0=$ common, $0=$ rare, $X=$ trace. 
TABLE 8

Calcareous Nannofossils From the Cretaceous Sediments of Site 401

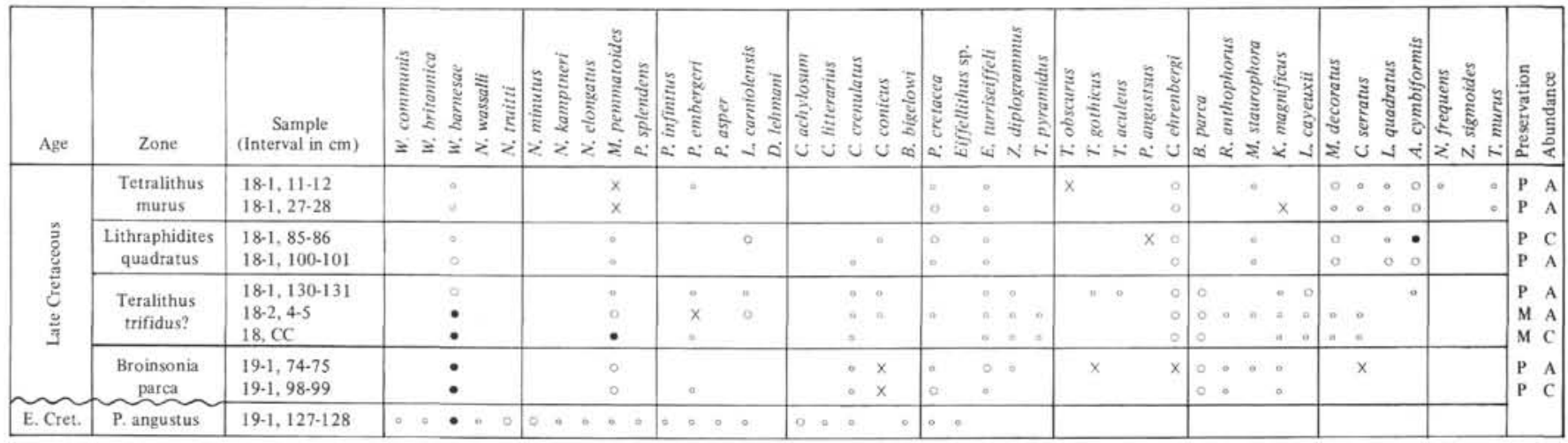

Note: Preservation: $\mathrm{P}=$ poor, $\mathrm{G}=$ good, $\mathrm{M}=$ moderate. Abundance: $\mathrm{T}=$ trace, $\mathrm{R}=\mathrm{rare}, \mathrm{C}=$ common, $\mathrm{A}$-abundant. $\bullet=$ abundant, $\mathrm{s}=$ common, $\bullet=$ rare, $\mathrm{X}=\mathrm{trace}$.

TABLE 9

Calcareous Nannofossils From the Upper Eocene Sediments of Hole 402A

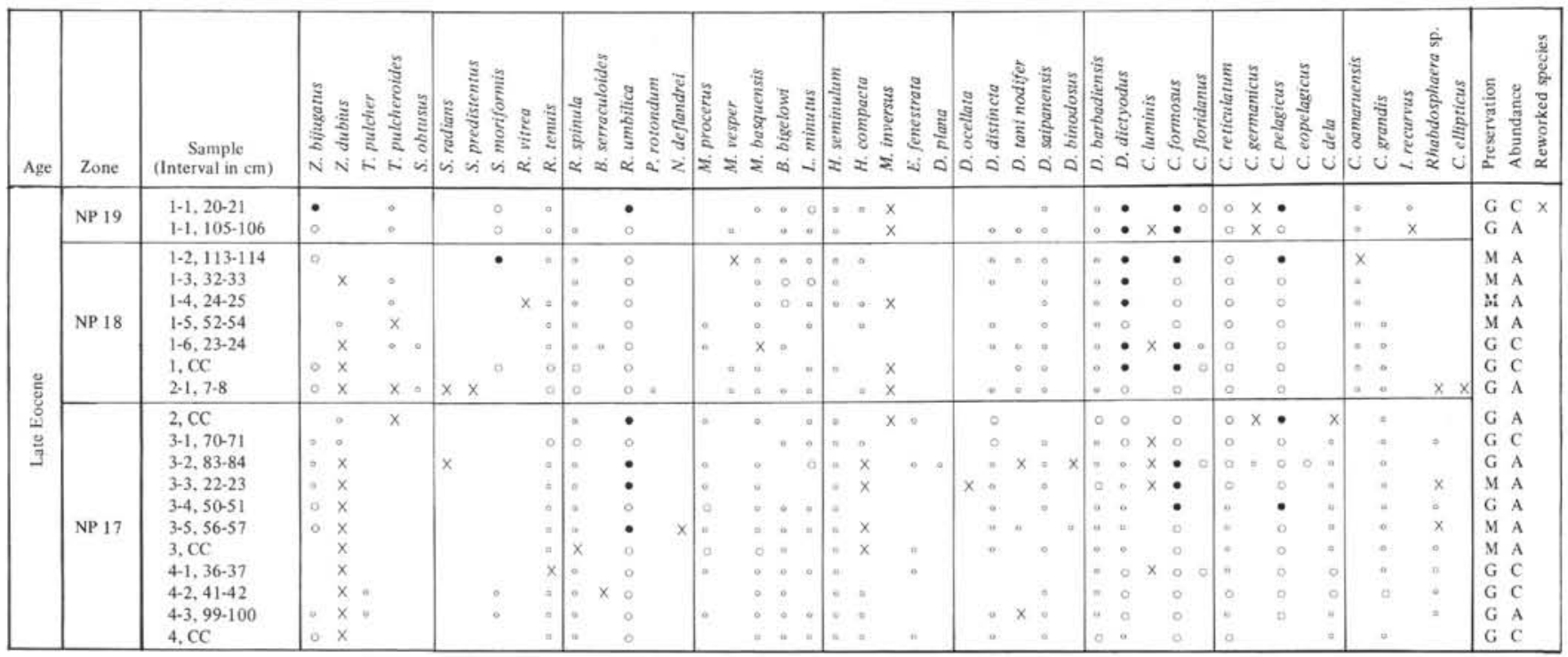

Note: Preservation: $\mathrm{P}=$ poor, $\mathrm{G}=$ good, $\mathrm{M}$-moderate. Abundance: $\mathrm{T}=$ trace, $\mathrm{R}=\mathrm{rare}, \mathrm{C}=$ common, $\mathrm{A}=\mathrm{ab}$ undant. $\bullet=\mathrm{abundant}$, oncommon, $0=\mathrm{rare}, \mathrm{X}=\mathrm{trace}$.

binodosus Zone (NP 10/NP 11) of the lower Eocene. Few specimens of $M$. bramlettei, which are typical for the nannoplankton Zone NP 10, occur in several samples from Core 34 to Core 42 . The sediments of Core 42 to Core 52 ( 384.0 to $489.0 \mathrm{~m}$ ) are barren of nannofossils.

\section{SITE 404}

(lat $56^{\circ} 03.13$ ' ; long $23^{\circ} 14.95^{\prime} \mathrm{W}$; water depth: $2306 \mathrm{~m}$ )

Site 404 is located on the southwest margin of the Rockall Plateau five miles south of Site 403. The upper part of this hole is cored discontinuously.

Pleistocene sediments were recovered in Core 1 (NN 21) and Core 2 (NN 19) from 0 to 28.0 meters (Table 14). Core 3 (104.0 to $113.0 \mathrm{~m}$ ) belongs to the lower Pliocene (nannoplankton Zone NN 12). The D. quinqueramus Zone (NN 11) occurs in Core $4(170.5$ to $180.0 \mathrm{~m})$. Core 5 probably belongs to the stratigraphic interval of the $D$. hamatus/ $D$. calcaris Zone (NN 9/NN 10), but a precise age determination is not possible, due to the scarcity of discoasters and their poor preservation. Core 6 (189.0 to $199.0 \mathrm{~m})$ probably belongs to the middle Miocene as indicated by the presence of the large variety of Coccolithus pelagicus $(=C$. miopelagicus), which seems to be typical for the nannoplankton Zones NN 6 and NN 7. This miocene sequence is underlain by lower Eocene sediments of the $D$. lodoensis Zone (NP 13) in Core 7 to Core 9 (Table 15). The hiatus represents an interval of about $36 \mathrm{~m} . \mathrm{y}$. Discoasters are rare in this section; few specimens of Imperiaster obscurus have been observed.

The Marthasterites tribrachiatus Zone (NP 12) is present from Core 10 to Core 16 , Section $1 ; D$. lodoensis and $M$. tribrachiatus are scarce. Poorly preserved nannofossils are abundant from Core 11 downwards. The sequence from Core 11, Section 2, to at least Core 21 (286.0 to $341.5 \mathrm{~m})$ belongs to the $M$. contortus/D. binodosus Zone (NP 10/NP $11) ; M$. bramlettei was found only in Sample 21-4, 47-48 $\mathrm{cm}$. Nannofossils are rare from Core 17 downwards, which is probably due to the high amount of terrigenous material. 
TABLE 10

Calcareous Nannofossils From the Cretaceous Sediments of Hole 402A

\begin{tabular}{|c|c|c|c|c|c|c|c|c|c|c|c|c|c|c|c|c|c|c|c|c|c|c|c|}
\hline Age & Zone & $\begin{array}{c}\text { Sample } \\
\text { (Interval in } \mathrm{cm} \text { ) }\end{array}$ & 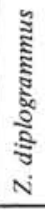 & & & $\begin{array}{l}3 \\
0 \\
\vdots \\
\vdots \\
3 \\
3\end{array}$ & 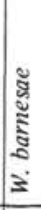 & & & & & & & & 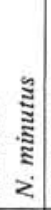 & 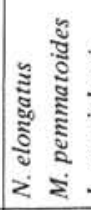 & & ڤั & 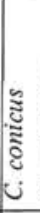 & & & 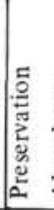 & 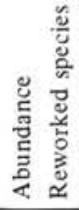 \\
\hline 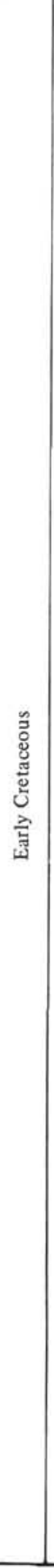 & $\begin{array}{l}\text { Parhabdolithus } \\
\text { angustus }\end{array}$ & $\begin{array}{l}5-1,14-15 \\
5-2,5-6 \\
6-1,145-146 \\
11-1,4-5 \\
11-1,87-88 \\
11-2,144-145 \\
11-3,14-16 \\
11-4,22-23 \\
11, \mathrm{CC} \\
12-1,83-84 \\
12-2,9-10 \\
12-2,83-84 \\
12, \mathrm{CC} \\
13-1,90-91 \\
13-2,45-47 \\
13-2,134-135 \\
13, \mathrm{CC} \\
14-1,47-48 \\
14-2,40-41 \\
14-3,36-37 \\
14-3,106-107 \\
14, \mathrm{CC} \\
15-2,121-123 \\
15-3,41-42 \\
15-3,102-103 \\
15-4,135-136 \\
15-5,52-53 \\
15, \mathrm{CC} \\
16-1,44-45 \\
16-2,19-21 \\
16-2,98-100 \\
16, \mathrm{CC} \\
17-1,44-46 \\
17-1,117-118 \\
17-2,30-32 \\
17, \mathrm{CC} \\
18-1,105-106 \\
18-2,46-48 \\
18-3,18-20 \\
18-4,20-22 \\
18, \mathrm{CC} \\
19-1,92-93 \\
19-2,34-35 \\
19-2,124-125 \\
19-3,14-15 \\
19-3,121-122 \\
19-4,119-120 \\
20-1,52-53 \\
20-3,31-32 \\
20-3,28-29 \\
20-3,130-131 \\
20-4,20-22 \\
21-1,124-126 \\
21-2,36-38 \\
21-2,117-118 \\
21-3,91-93 \\
21-3,111-112 \\
21-4,32-33 \\
21-4,91-92 \\
21-5,32-33 \\
21-6,124-125 \\
21, \mathrm{CC} \\
\end{array}$ & $\begin{array}{l}x \\
x \\
x \\
0 \\
x \\
\\
x \\
x \\
x\end{array}$ & 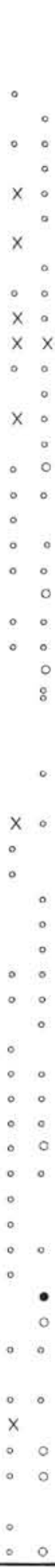 & $\begin{array}{l}x \\
x \\
x \\
x \\
x \\
x \\
x \\
x \\
x \\
x \\
x \\
x \\
x \\
x \\
x\end{array}$ & 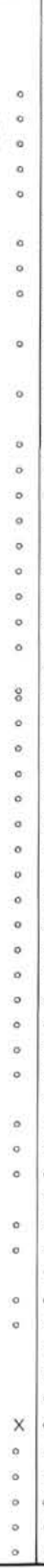 & 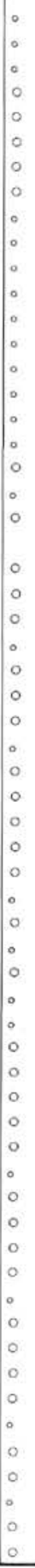 & $\begin{array}{l}x \\
x \\
x \\
x \\
\\
x \\
x \\
x \\
0 \\
x \\
x \\
x \\
x \\
x \\
x \\
x \\
\\
x \\
x \\
x \\
x \\
x \\
x \\
0 \\
0\end{array}$ & $\begin{array}{r}0 \\
x \\
x \\
0 \\
0 \\
x \\
x \\
x \\
0 \\
0 \\
0 \\
0 \\
0 \\
\times \\
0 \\
0 \\
0\end{array}$ & 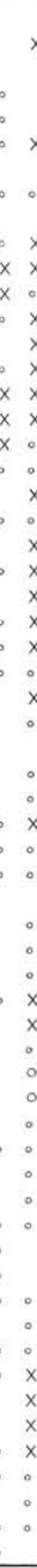 & 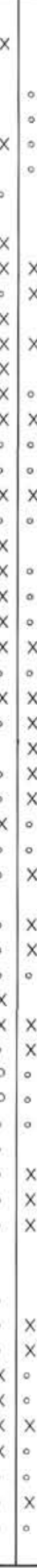 & $\begin{array}{l}0 \\
0 \\
x \\
x \\
x \\
x \\
x \\
x \\
x \\
0 \\
x \\
x\end{array}$ & 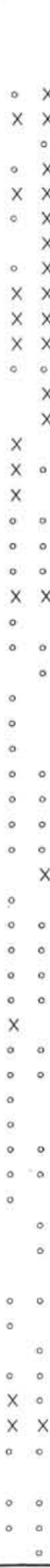 & 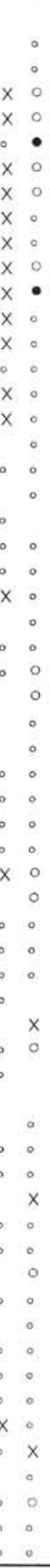 & $\begin{array}{l}0 \\
0 \\
0 \\
0 \\
0 \\
0 \\
0 \\
0 \\
0\end{array}$ & $\begin{array}{lll} & x \\
& \\
x & \\
x & \\
x & \\
x & \\
& x\end{array}$ & 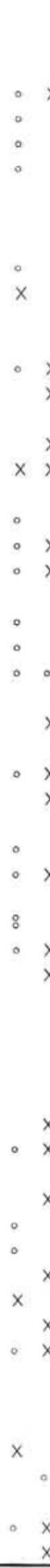 & 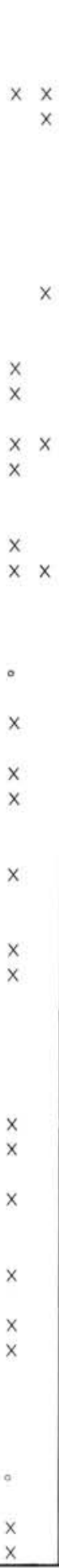 & $\begin{array}{l}x \\
x \\
0 \\
0 \\
x \\
x\end{array}$ & 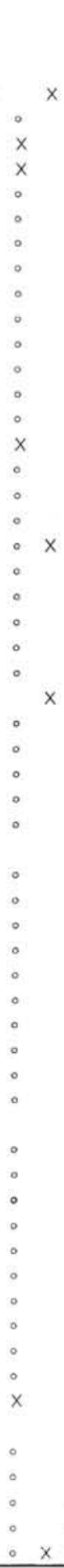 & $\begin{array}{l}x \\
0 \\
x \\
x \\
x \\
x \\
x \\
x \\
x \\
x\end{array}$ & $\begin{array}{l}\mathrm{M} \\
\mathrm{M} \\
\mathrm{M} \\
\mathrm{M} \\
\mathrm{M} \\
\mathrm{M} \\
\mathrm{M} \\
\mathrm{M} \\
\mathrm{M} \\
\mathrm{M} \\
\mathrm{M} \\
\mathrm{M} \\
\mathrm{M} \\
\mathrm{M} \\
\mathrm{M} \\
\mathrm{M} \\
\mathrm{M} \\
\mathrm{M} \\
\mathrm{M} \\
\mathrm{P} \\
\mathrm{M} \\
\mathrm{M} \\
\mathrm{M} \\
\mathrm{M} \\
\mathrm{M} \\
\mathrm{M} \\
\mathrm{M} \\
\mathrm{M} \\
\mathrm{M} \\
\mathrm{M} \\
\mathrm{M} \\
\mathrm{G} \\
\mathrm{G} \\
\mathrm{G} \\
\mathrm{G} \\
\mathrm{G} \\
\mathrm{G} \\
\mathrm{G} \\
\mathrm{G} \\
\mathrm{G} \\
\mathrm{M} \\
\mathrm{M} \\
\mathrm{G} \\
\mathrm{G} \\
\mathrm{G} \\
\mathrm{M} \\
\mathrm{M} \\
\mathrm{G} \\
\mathrm{G} \\
\mathrm{G} \\
\mathrm{G} \\
\mathrm{G} \\
\mathrm{G} \\
\mathrm{G} \\
\mathrm{G} \\
\mathrm{G} \\
\mathrm{G} \\
\mathrm{G} \\
\mathrm{G} \\
\mathrm{G} \\
\mathrm{G} \\
\mathrm{G} \\
\\
\end{array}$ & $\begin{array}{l}\mathrm{T} \\
\mathrm{T} \\
\mathrm{T} \\
\mathrm{C} \\
\mathrm{C} \\
\mathrm{C} \\
\mathrm{F} \\
\mathrm{C} \\
\mathrm{F} \\
\mathrm{F} \\
\mathrm{F} \\
\mathrm{F} \\
\mathrm{R} \\
\mathrm{R} \\
\mathrm{F} \\
\mathrm{F} \\
\mathrm{F} \\
\mathrm{F} \\
\mathrm{F} \\
\mathrm{F} \\
\mathrm{F} \\
\mathrm{F} \\
\mathrm{F} \\
\mathrm{F} \\
\mathrm{C} \\
\mathrm{C} \\
\mathrm{F} \\
\mathrm{F} \\
\mathrm{F} \\
\mathrm{F} \\
\mathrm{C} \\
\mathrm{C} \\
\mathrm{C} \\
\mathrm{C} \\
\mathrm{C} \\
\mathrm{F} \\
\mathrm{F} \\
\mathrm{R} \\
\mathrm{C} \\
\mathrm{C} \\
\mathrm{C} \\
\mathrm{C} \\
\mathrm{C} \\
\mathrm{F} \\
\mathrm{C} \\
\mathrm{C} \\
\mathrm{F} \\
\mathrm{R} \\
\mathrm{C} \\
\mathrm{F} \\
\mathrm{C} \\
\mathrm{C} \\
\mathrm{C} \\
\mathrm{C} \\
\mathrm{F}\end{array}$ \\
\hline
\end{tabular}

Note: Preservation: $\mathrm{P}=$ poor, $\mathrm{G}=$ good, $\mathrm{M}=$ moderate. Abundance: $\mathrm{T}=$ trace, $\mathrm{R}=\mathrm{rare}, \mathrm{C}=$ common, $\mathrm{A}=\mathrm{abundant}, \bullet=\mathrm{abundant}, \mathrm{g}=$ common, $0=$ rare, $X=$ trace. 
TABLE 11

Calcareous Nannofossils From the Cretaceous Sediments of Hole 402A

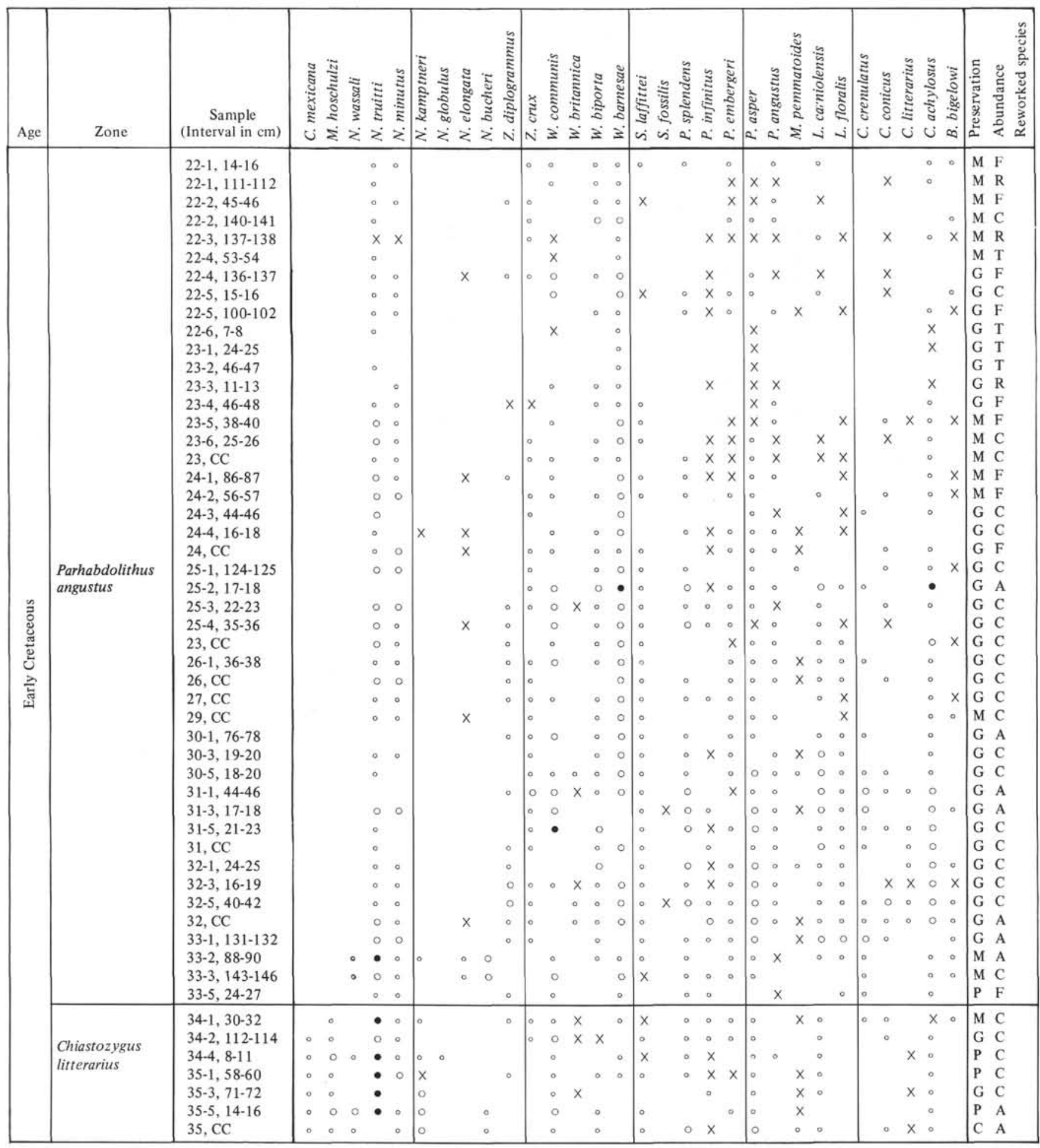

Preservation: $\mathrm{P}=$ poor $, \mathrm{G}=\mathrm{good}, \mathrm{M}=$ moderate. Abundance: $\mathrm{T}=\operatorname{trace}, \mathrm{R}=\mathrm{rare}, \mathrm{C}=$ common, $\mathrm{A}=\mathrm{abundant} . \bullet=\mathrm{abundant}, \mathrm{o}=\mathrm{common}, \mathrm{o}=\mathrm{rare}, \mathrm{X}=\mathrm{trace}$. 
TABLE 12

Calcareous Nannofossils From the Oligocene to Quaternary Sediments of Site 403

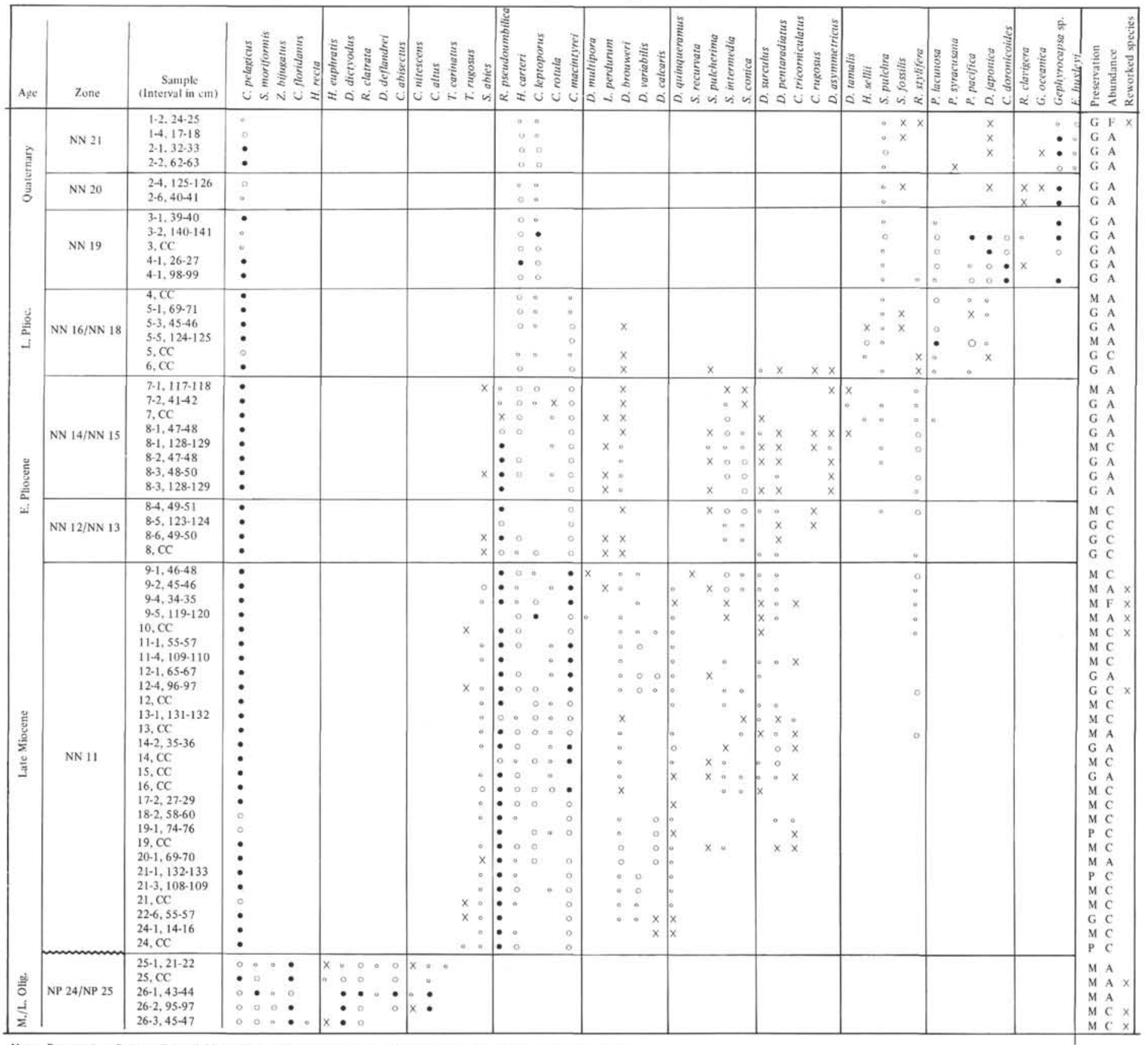


TABLE 13

Calcareous Nannofossils From the Lower to Middle Eocene Sediments of Site 403

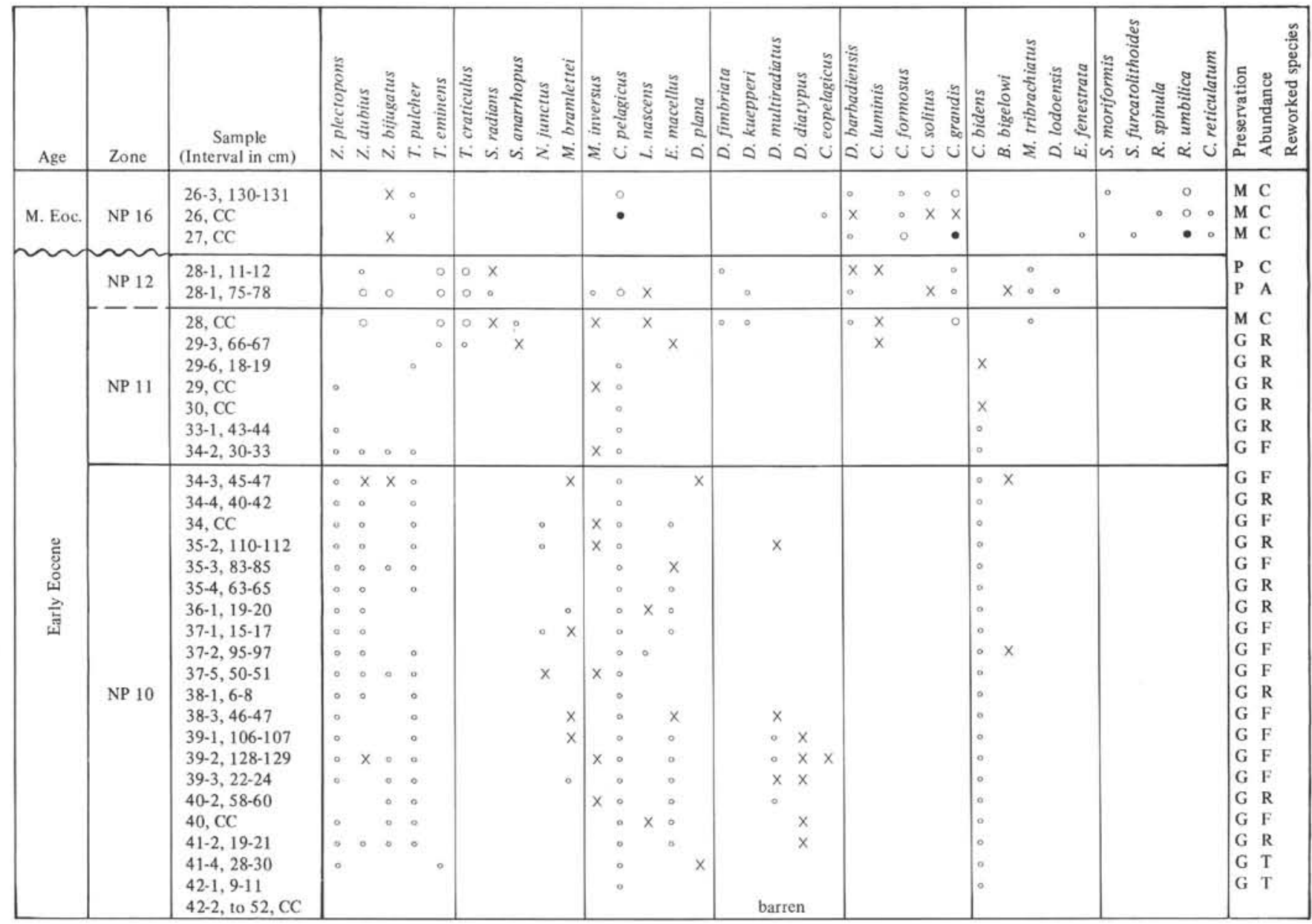

Note: Preservation: $\mathrm{P}=$ poor, $\mathrm{G}=\mathrm{good}, \mathrm{M}=$ moderate. Abundance: $\mathrm{T}=$ trace, $\mathrm{R}=\mathrm{rare}, \mathrm{C}=$ common, $\mathrm{A}=\mathrm{abundant} . \bullet=\mathrm{abundant}, \mathrm{O}=\mathrm{common}, \circ=\mathrm{rare}, \mathrm{X}=\mathrm{trace}$.

TABLE 14

Calcareous Nannofossils From the Middle Miocene to Quaternary Sediments of Site 404

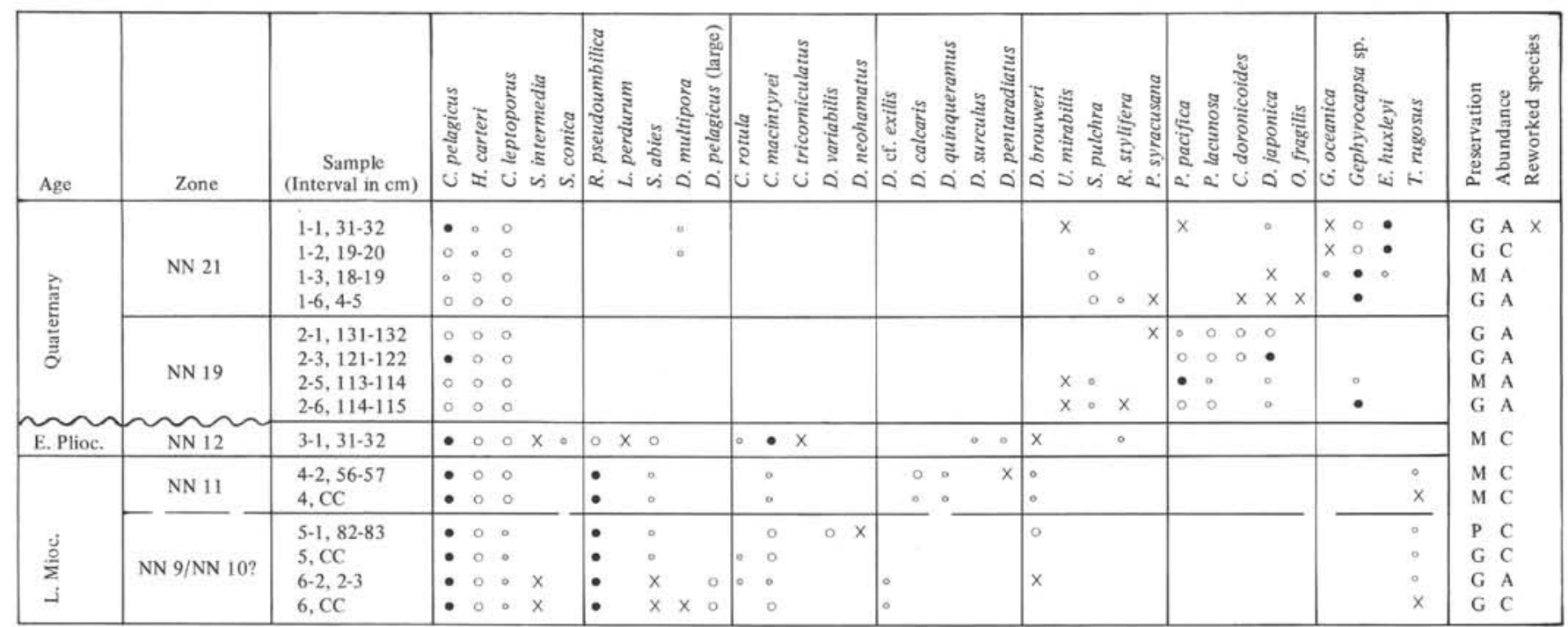

Note: Preservation: $\mathrm{P}=$ poor, $\mathrm{G}=$ good, $\mathrm{M}=$ moderate. Abundance: $\mathrm{T}=$ trace, $\mathrm{R}=\mathrm{rare}, \mathrm{C}=$ common, $\mathrm{A}=\mathrm{abundant} . \bullet=$ abundant, $\mathrm{o}=\mathrm{common}, \mathrm{o}=\mathrm{rare}, \mathrm{X}=\mathrm{trace}$. 
TABLE 15

Calcareous Nannofossils From the Lower Eocene Sediments of Site 404

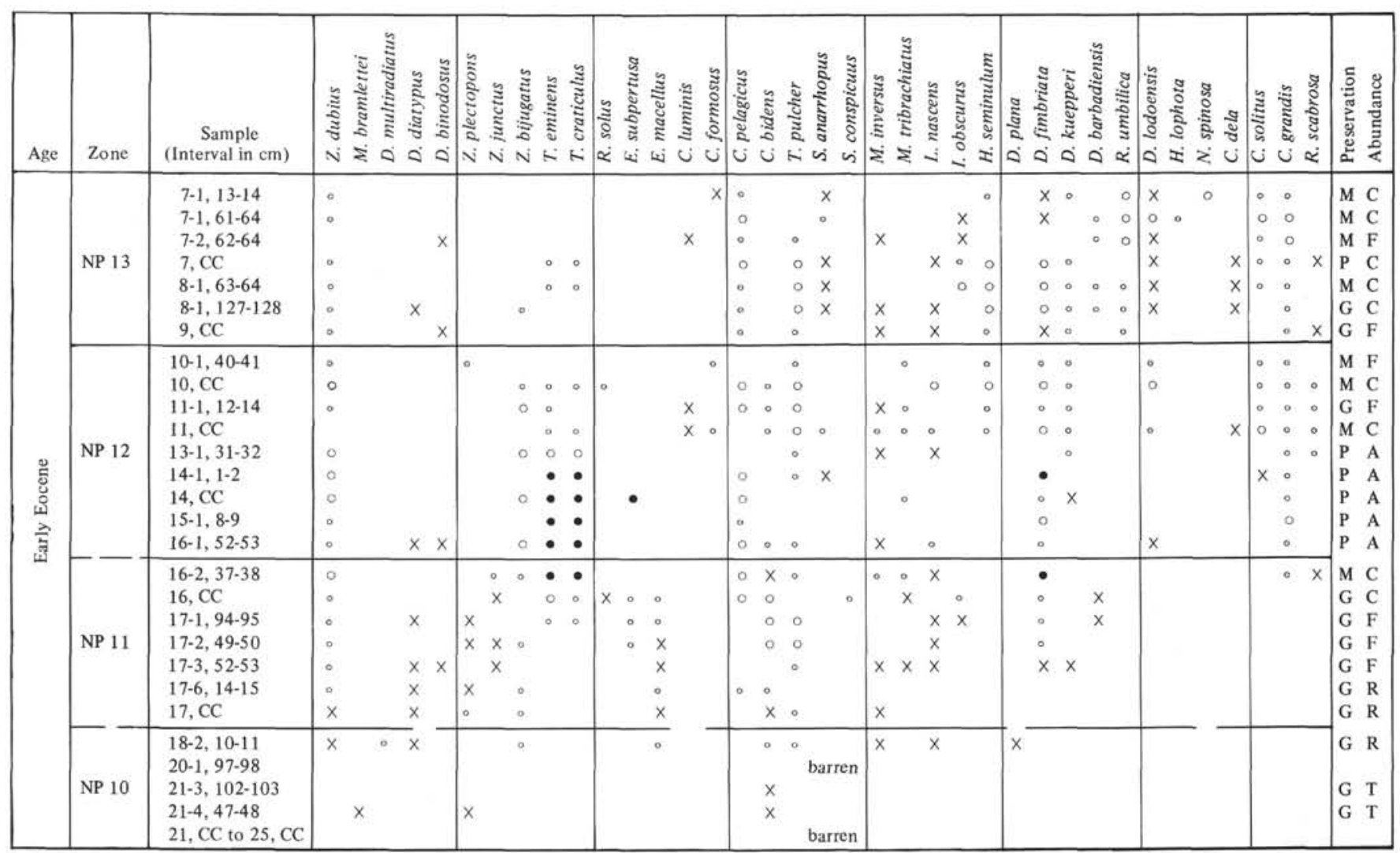

Note: Preservation: $\mathrm{P}=$ poor, $\mathrm{G}=$ good, $\mathrm{M}=$ moderate. Abundance: $\mathrm{T}=$ trace, $\mathrm{R}=\mathrm{rare}, \mathrm{C}=$ common, $\mathrm{A}=\mathrm{abundant} . \bullet=\mathrm{abundant}, \mathrm{o}=\mathrm{common}, \mathrm{o}=\mathrm{rare}, \mathrm{X}=\mathrm{trace}$.

Sediments of Core 22 to Core 26 (341.5 to $389.0 \mathrm{~m})$ are barren of nannofossils.

\section{SITE 405}

(lat $55^{\circ} 20.18^{\prime} \mathrm{N}$; long $22^{\circ} 03.49^{\prime} \mathrm{W}$; water depth: $2958 \mathrm{~m}$ )

Site 405 was drilled at the foot of the east-west-trending transform fault marking the transform part of the northwest margin of the Rockall Plateau. Pleistocene sediments (NN 21 to NN 19) rich in nannofossils were recovered in Core 1 to Core 5 ( 0 to $46.0 \mathrm{~m}$ ) (Table 16), but in several samples the content of nannofossils is diluted by the high input of terrigenous material containing reworked Cretaceous and Eocene species. A hiatus, which represents an interval of about $3.2 \mathrm{~m}$.y., lies between Core 5 and Core 6 ; the entire Pliocene sequence is missing and only a part of the lowermost Pliocene (NN 12) is represented in Core 6.

The upper Miocene (D. quinqueramus Zone, NN 11) in Core 7 is underlain by sediments of the middle Eocene $D$. sublodoensis Zone (NP 14) determined from Core 8 to Core 11, Section 1. The hiatus between Cores 7 and 8 represents an interval of about 43 m.y.; well-preserved nannofossils are abundant. The lower Eocene (Table 17) is represented from Sample 11, CC to Sample 43, CC, the D. lodoensis Zone, NP 13 from Sample 11, CC to Sample 31-3, 105-106 $\mathrm{cm}$ and the $M$. tribrachiatus Zone, NP 12 from Core 32 to Core 43). The nannofossils from Zone NP 13 are well preserved; few specimens of Imperiaster obscurus were ob- served within it. Preservation is poor in the nannoplankton Zone NP 12, where they are overgrown and broken.

\section{SITE 406}

(lat $55^{\circ} 15.50^{\prime} \mathrm{N}$; long $22^{\circ} 05.41^{\prime} \mathrm{W}$; water depth: $2907 \mathrm{~m}$ )

Site 406 is situated south of the east-west scarp forming part of the southwest margin of the Rockall Plateau. Pleistocene sediments are recovered in Core 1 (NN 21) and in Core 2 (NN 19) (Table 18). Well-preserved nannofossils are abundant.

The lower Pliocene is represented in Core 3 (NN 14/NN $15)$ and Core 4 (NN 12) from 138.0 to 223.5 meters. The $D$. quinqueramus Zone (NN 11) of the upper Miocene is determined from Core 5 to Core 11 (318.5 to $442.0 \mathrm{~m}$ ). Sediments are rich in slightly etched and broken nannofossils, but discoasters are scarce. A precise age determination is not possible. It probably belongs to the middle Miocene as suggested by the presence of the large variety of $C$. pelagicus. Broken and etched nannofossils are abundant; discoasters are scarce or missing.

The $D$. exilis Zone (NN6) was recovered from Core 16 to Core 19 (480.5 to $518.0 \mathrm{~m})$ with Cyclicargolithus abisectus and $D$. exilis. From Core 20 to Core 23, Section 4, the Sphenolithus heteromorphus Zone (NN 5) is represented. Nannofossils are abundant, but they are severely broken and etched. The lower Miocene is encountered from Core 24 to 
TABLE 16

Calcareous Nannofossils From the Lower Eocene to the Quaternary Sediments of Site 405

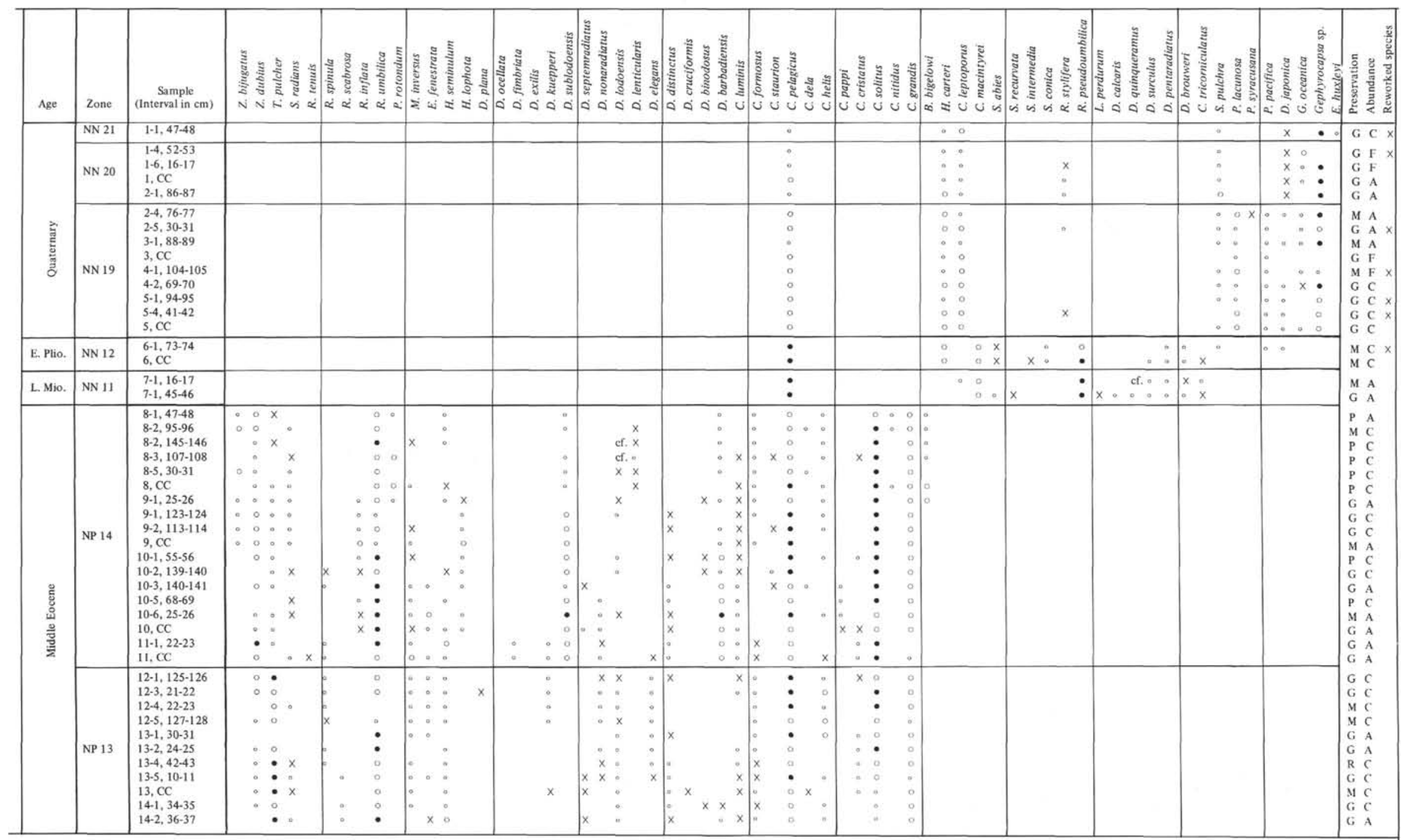

Note: Preservation: $P=$ poor, $G=$ good, $M=$ moderate. Abundance: $T=$ trace, $R=$ rare, $C=$ common, $A=$ abundant, $\bullet=$ abundant, $0=$ common, $=\pi$ rare, $x=$ trace. 
TABLE 17

Calcareous Nannofossils From the Lower Eocene Sediments of Site 405

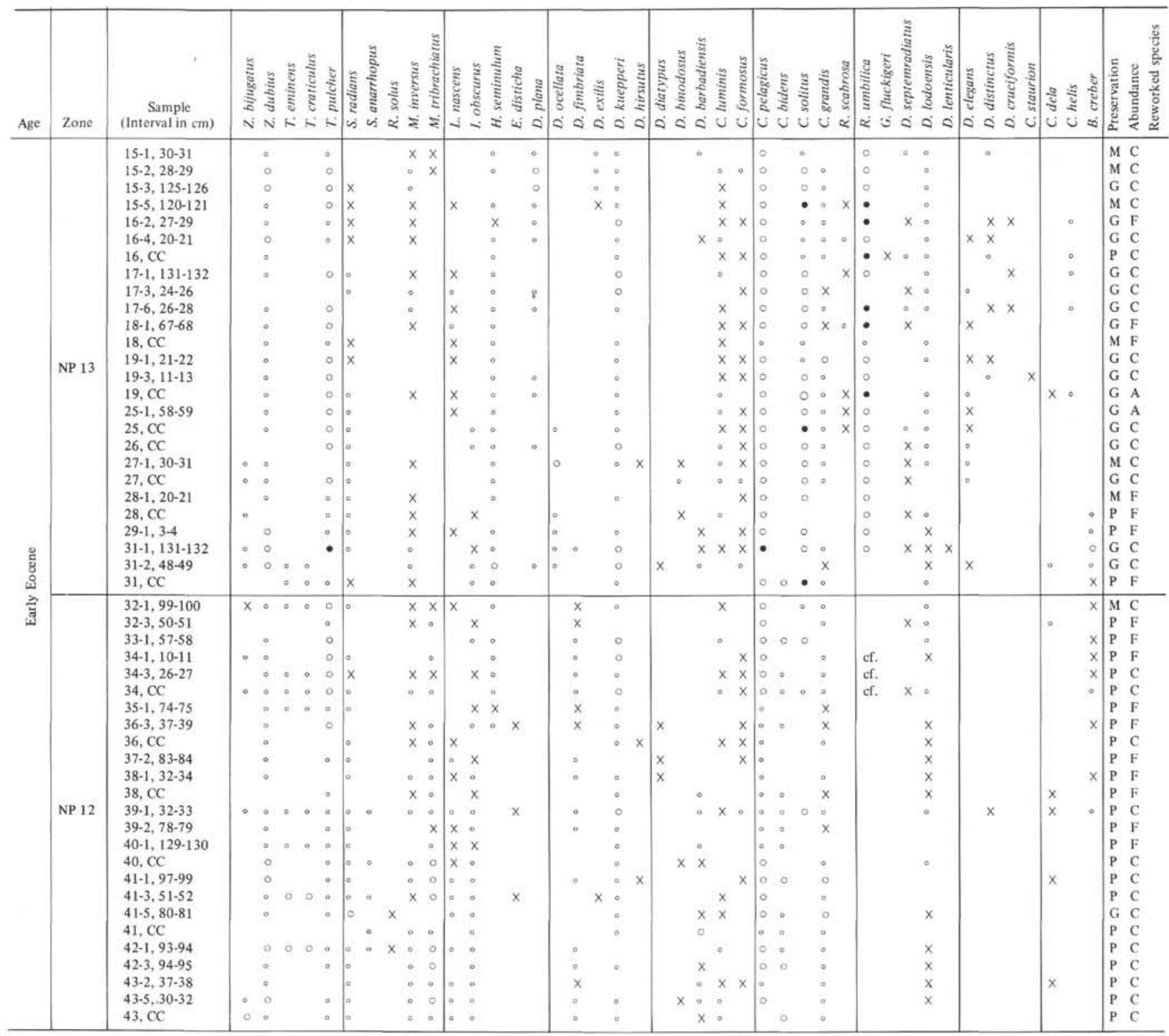

Note: Preservation: $\mathrm{P}=$ poor, $\mathrm{G}=$ good, $\mathrm{M}=$ moderate. Abundance: $\mathrm{T}=$ trace, $\mathrm{R}=\mathrm{rare}, \mathrm{C}=$ common, $\mathrm{A}=\mathrm{ab}$ andant. $\bullet=$ abundant, $\mathrm{o}=\mathrm{common}, \mathrm{e}=\mathrm{rare}, \mathrm{X}=$ trace.

Core 27 (556.0 to $594.0 \mathrm{~m})$. The sediments belong to the Triquetrorhabdulus carinatus Zone (NN 1).

The Oligocene/Miocene boundary is drawn between Core 27 and Core 28 on the basis of the extinction of Helicosphaera recta. Sphenoliths are absent. The Sphenolithus ciperoensis Zone (NP 25) of the upper Oligocene is determined from Sample 28-1, 34-35 cm to Sample 32-2, $15-17 \mathrm{~cm}$ by the presence of $T$. carinatus .

The sequence between Sample 32-4, 95-96 cm and Sample 36-1, 107-108 cm belongs to the Sphenolithus distentus Zone (NP 24) of the middle Oligocene. The nannoplankton assemblage with Discoaster deflandrei and Chiasmolithus altus is comparable to the middle Oligocene assemblages from the Norwegian-Greenland Sea and the North Atlantic (Leg 12). A hiatus which represents an interval of about 8 m.y. lies between the middle Oligocene and the underlying upper Eocene (NP 19/NP 20) (Table 19). This combined zone is determined from Sample 36-2, 27-28 cm to Core 42, Section 1 . Nannofossils are abundant but poorly preserved. In several layers nannofossils are rare due to recrystallization; discoasters and Isthmolithus recurvus are scarce. Cribrocentrum reticulatum, Recticulofenestra umbilica, and Dictyococcites dictyodus are the most abundant species. Reworked species from the middle Eocene occur in several samples. A slump of middle Eocene sediments (NP 14) is intercalated in the upper Eocene sequence of Core 45, Section 5. The Chiasmolithus oamaruensis Zone (NP 18) is recognized from Sample 42-2, 15-16 cm to Sample 45, CC (730.0 to $765.0 \mathrm{~m}$ ).

The upper Eocene (NP 18) is underlain by middle Eocene (NP 14); this hiatus represents an interval of about 6.5 m.y. The Discoaster sublodoensis Zone (NP 14) was recovered 
TABLE 18

Calcareous Nannofossils From the Oligocene to the Quaternary Sediments of Site 406

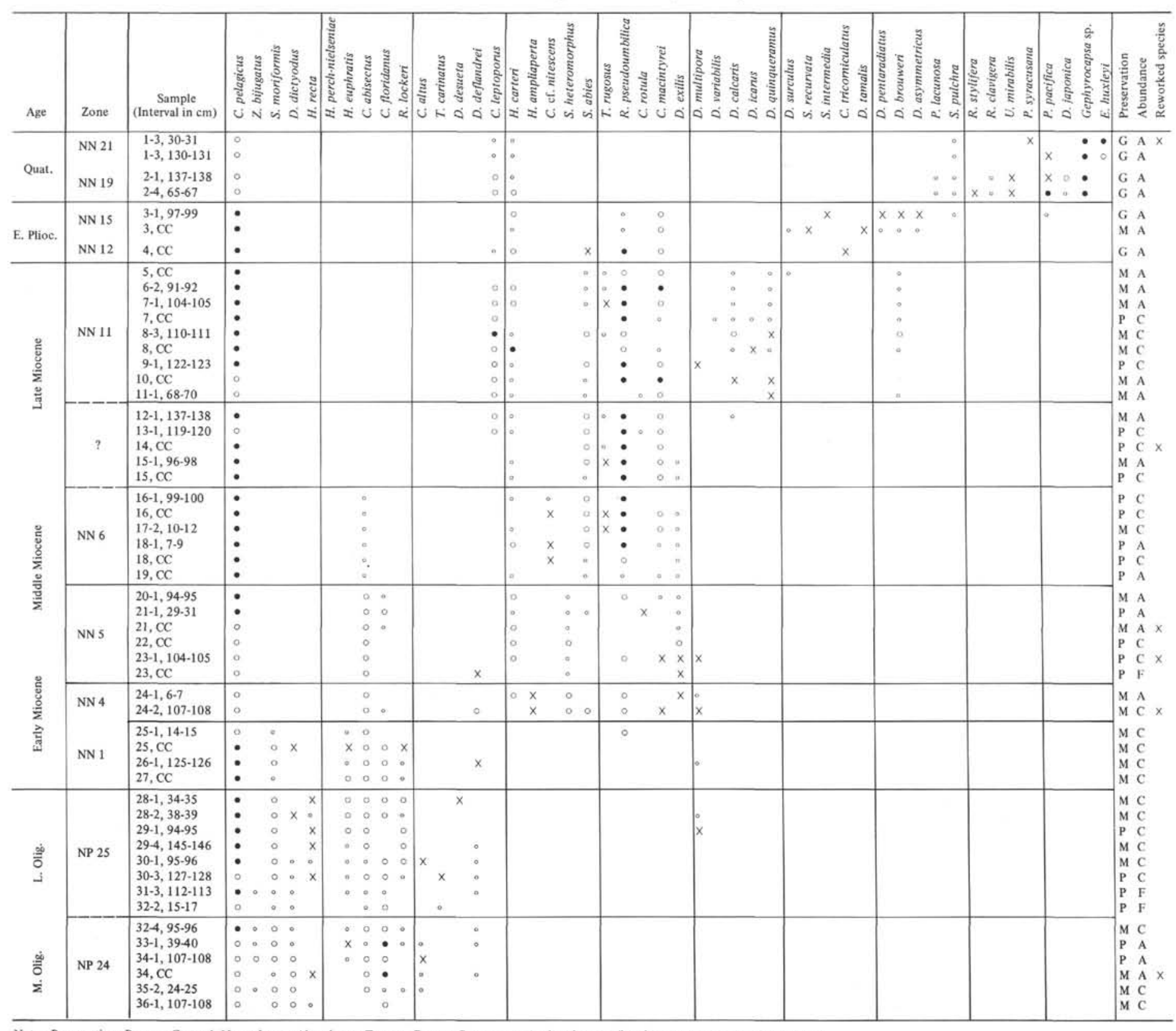


TABLE 19

Calcareous Nannofossils From the Middle to Upper Eocene Sediments of Site 406

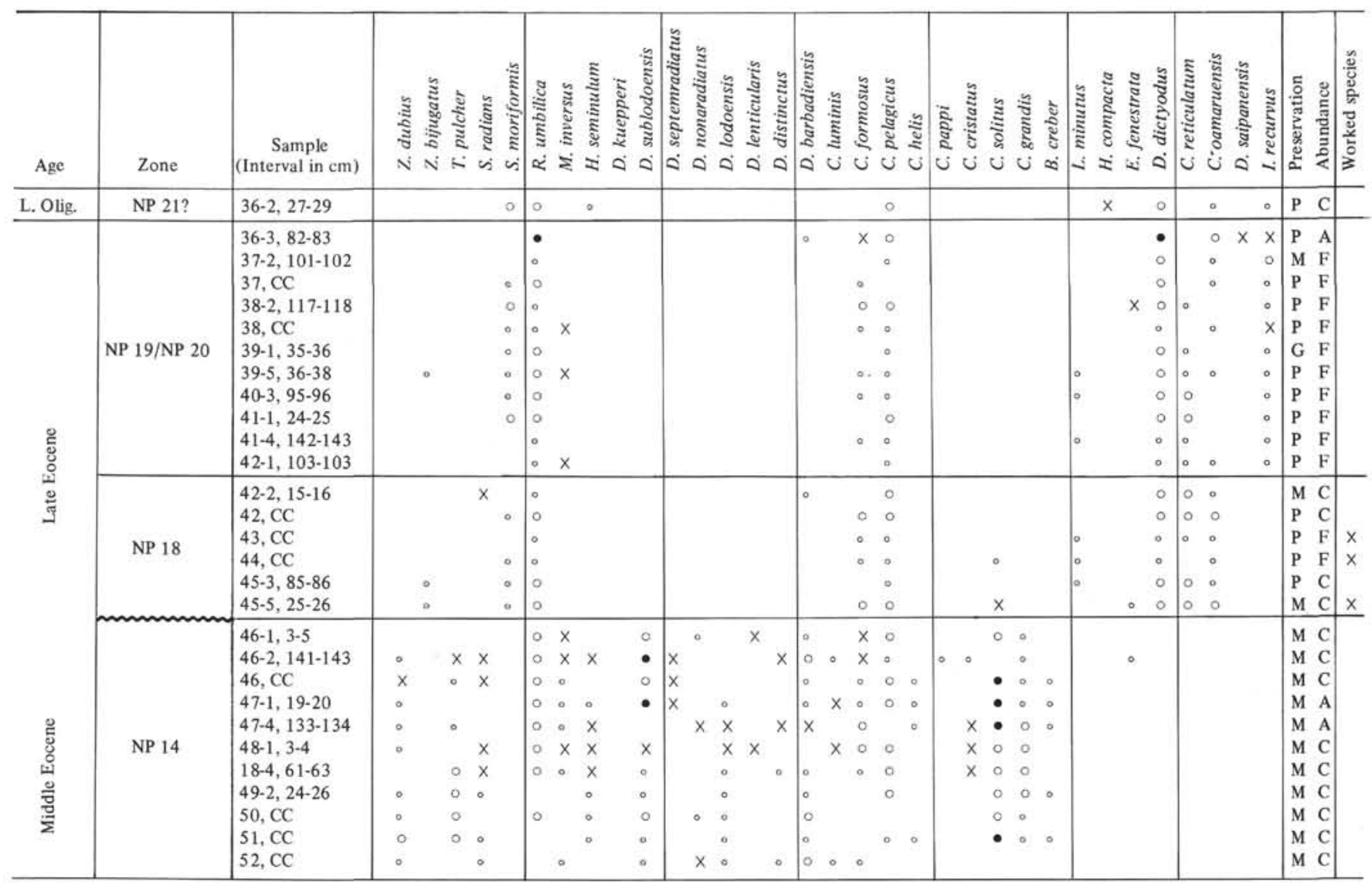

Note: Preservation: $\mathrm{P}=$ poor, $\mathrm{G}=$ good, $\mathrm{M}=$ moderate. Abundance: $\mathrm{T}=$ trace, $\mathrm{R}=\mathrm{rare}, \mathrm{C}=$ common, $\mathrm{A}=\mathrm{abundant} . \bullet=\mathrm{abundant}, \mathrm{o}=\mathrm{common}, \mathrm{o}=\mathrm{rare}, \mathrm{X}=\mathrm{trace}$.

from Sample 45, CC to Sample 52, CC (765.0 to $831.0 \mathrm{~m})$ Nannofossils are abundant but show signs of dissolution; $D$. sublodoensis is abundant in the upper part of this zone whereas $D$. lodoensis is rare throughout the sequence.

The zones determined at each site are given in Table 1 and the distribution of the most important nannofossils in the Paleogene of the North Atlantic and other areas is shown in Table 20.

\section{Biostratigraphy}

\section{CRETACEOUS}

Cretaceous sediments were recovered in the Bay of Biscay at Hole 400A, Site 401, and Hole 402A. Oldest nannofossil-bearing sediments are of early Aptian age (Chiastozygus litterarius Zone) in Hole 402A (Cores 34 and 35). The Upper Jurassic/Lower Cretaceous limestones drilled at Site 401 are barren of nannofossils.

The calcareous marls to limestones of the $C$. litterarius Zone are rich in nannoconids, characteristic of marginal conditions (Thierstein, 1976). The most frequent species are Nannoconus truitti, $N$. wassilli, $N$. minutus, whereas $N$. kamptneri, $N$. bucheri, and $N$. elongatus are rare; they are accompanied by Micrantholithus obtusus, M. hoschulzi, Braarudosphaera bigelowi, and Conusphaera mexicana, all of which are considered to be typical of a near-shore environment. B. bigelowi becomes abundant in Sample 34-1,
30-32 cm. Coccoliths and related nannofossils are less abundant in these nannoconid-rich layers and often smaller compared with their normal size in open-ocean sediments.

The $P$. angustus Zone of the upper Aptian-lower Albian is encountered at Hole 400A, Site 401, and Hole 402A. In it the nannoplankton assemblages are distinguished by remarkable differences because they were deposited in different environments (see following section on paleoenvironment). The $P$. angustus Zone is defined from the first occurrence of this species or Lithastrinus floralis to the first occurrence of Prediscosphaera cretacea (Thierstein, 1971, 1973). In Hole $400 \mathrm{~A}$ it is possible to determine the Aptian/Albian boundary between Core 68 and Core 69 by the first occurrence of Hayesites albiensis, which is scarce throughout the Albian at this site; the species has been recognized only from the Albian (Manivit, 1971; Wilcoxon, 1972; Thierstein, 1973, 1976). H. albiensis was not observed at Hole 402A, which may be due to deposition in a different environment. The nannoplankton assemblages of the $P$. angustus Zone at Hole 400A are well diversified. The sediments are rich in nannofossils which, in almost all samples, show signs of dissolution and fragmentation. In general the dissolution is stronger in the dark layers which have a higher content of organic material and pyrite, than in the gray sediment where they are only slightly etched. It is assumed that this phenomenon is caused partially by 
TABLE 20

Distribution of the Most Important Nannofossils in the Paleogene of the North Atlantic and Other Areas

\begin{tabular}{|c|c|c|c|c|c|c|c|c|c|c|c|}
\hline Species & 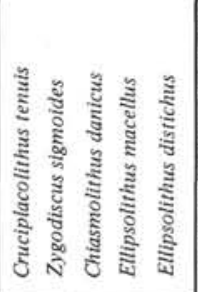 & 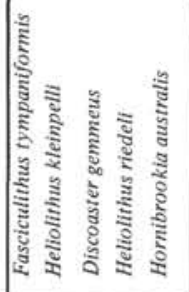 & 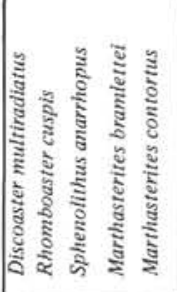 & 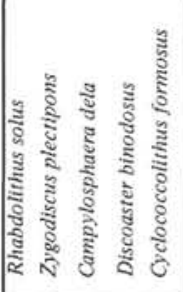 & 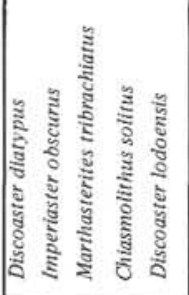 & 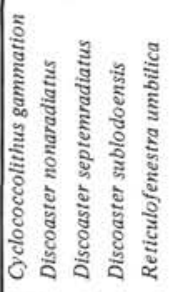 & 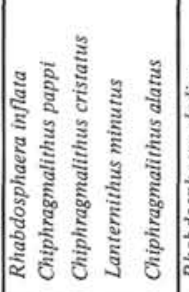 & 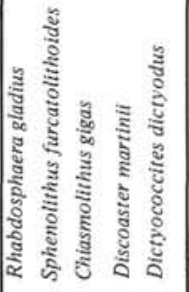 & 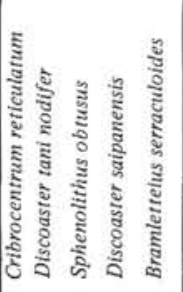 & 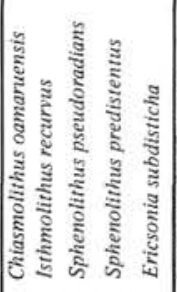 & 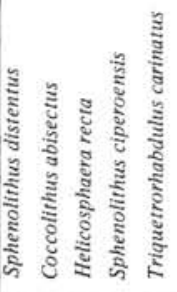 \\
\hline NP 25 Sphenolithus ciperoensis & & & & & & & & & & & \\
\hline NP $24 \quad$ Sphenolithus distentus & & & & & & & & & = & E & \\
\hline NP 23 Sphenolithus predistentus & & & & & & & & & E & & \\
\hline NP 22 Helicosphaera reticulata & & & & & & & & & E & & \\
\hline NP 21 Ericsonia subdisticha & & & & & & & & & - & & \\
\hline NP 20 Sphenolithus pseudoradians & & & & & & & & & 틀 & E & \\
\hline NP 19 Isthmolithus recurvus & & & & & & & & & & 䨐 & \\
\hline NP 18 Chiasmolithus oamaruensis & & & & & & & & & & & \\
\hline NP 17 Discoaster saipanensis & & & & & & & & & & & \\
\hline NP $16 \quad$ Discoaster tani nodifer & & & & & & & & & & 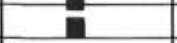 & \\
\hline NP 15 Chiphragmalithus alatus & & & & & & & & & - & & \\
\hline NP 14 Discoaster sublodoensis & & & & & & & & 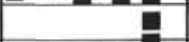 & & & \\
\hline NP 13 Discoaster lodoensis & & & & & & & & 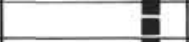 & & & \\
\hline NP 12 Marthasterites tribrachiatus & & & & & & E & & $\overline{\mathrm{E}}$ & & & \\
\hline NP11 Discoaster binodosus & & & & & & & & & & & \\
\hline NP $10 \quad$ Marthastrerites contortus & & & & & & & & & & & \\
\hline NP9 Discoaster multiradiatus & & & & & & & & & & & \\
\hline NP 8 Heliolithus riedeli & & & & & & & & & & & \\
\hline NP 7 Discoaster gemmeus & & & & & & & & & & & \\
\hline NP 6 Heliolithus kleinpelli & & & & & & & & & & & \\
\hline NP 5 Fasciculithus tympaniformis & & & & & & & & & & & \\
\hline NP $4 \quad$ Ellipsolithus macellus & & & & & & & & & & & \\
\hline NP 3 Chiasmolithus danicus & & & & & & & & & & & \\
\hline NP 2 Cruciplacolithus tenuis & & & & & & & & & & & \\
\hline NP 1 Markalius inversus & & & & & & & & & & & \\
\hline
\end{tabular}


different physicochemical conditions in the surface sediments and the bottom water and by deposition of these sediments near the CCD. The amount of detrital material is often slightly higher in the black layers.

The Prediscosphaera cretacea Zone of the middle Albian and the Eiffellithus turriseiffeli Zone of the upper Albianlower Cenomanian are recognized from Core 65, Section 1, to Core 62 at Hole $400 \mathrm{~A}$. The boundary between the two zones is defined by the first occurrence of $E$. turriseiffeli (Thierstein, 1971). The abundant nannofossils are fragile and strongly affected by dissolution, mainly in the uppermost part of the interval; often only the outer rims are preserved, whereas the central areas of the shields are broken. In general, an enrichment of dissolution-resistant spécies can be observed. $P$. cretacea and $E$. turriseiffeli are only scarce. The extensive dissolution of nannofossils in the uppermost part of the Albian sediments indicates a rise of the CCD, which may be due to further subsidence of Site 400 or a drop in temperatures brought on by the influx of coldwater currents. Penetration of boreal dinoflagellates far to the south in late Albian-Cenomanian time is reported by Norris and Dörhöfer (1977). The Aptio-Albian assemblages are dominated by species of the genera Watznaueria, Parhabdolithus, and Cretarhabdulus. Lithraphidites carniolensis, Manivitella pemmatoides, and Corollithion achylosum are abundant in several samples.

Between the Lower and Upper Cretaceous recovered at Hole $400 \mathrm{~A}$ and Site 401 lies a hiatus of at least 28 to $30 \mathrm{~m}$.y. The thickness of the Upper Cretaceous sequence is extremely reduced, the zones being represented by a few centimeters of sediments. They are rich in nannofossils strongly affected by dissolution and fragmentation mainly in Hole $400 \mathrm{~A}$ where the Late Cretaceous sediments were deposited in a deep basin.

The Broinsonia parca Zone of the upper Campanian is encountered at Site 401 in the uppermost part of Core 19. The Tetralithus trifidus Zone of the uppermost Campanian and lowermost Maestrichtian is present in Hole 400A in Sample 61, CC and at Site 401 in Core 18. T. trifidus is abundant in Hole 400A, whereas it was not found at Site 401 where the stratigraphic interval is marked by abundant Lucianorhabdus cayeuxii. The latter species is regarded to be typical of boreal, marginal conditions (Thierstein, 1976). The results from Leg 48 suggest that the presence or absence of $L$. cayeuxii seem to be more controlled by water depth or distance from the continent than by water temperature. This suggestion is confirmed by the occurrence of $T$. murus, a tropical-subtropical species (Worsley and Martini, 1970 ) in the uppermost Maestrichtian at Site 401. Its presence indicates warm water temperatures in the Bay of Biscay during this time.

The Lithraphidites quadratus Zone of the lower Maestrichtian is present in Hole 400A and at Site 401; L. quadratus is very abundant at Site 401, but rare in Hole 400A; this scarcity is not attributed to dissolution only.

In Hole $400 \mathrm{~A}$ the $L$. quadratus Zone is overlain by the Heliolithus riedeli Zone (NP 8) of the upper Paleocene. In Hole 401 the $T$. murus Zone is overlain by the Chiasmolithus danicus Zone (NP 3) of the Danian. The Cretaceous/Tertiary boundary is not recorded in the Bay of Biscay.

\section{Paleoenvironment}

Hole 400A is located in the Bay of Biscay at the foot of the Meriadzek escarpment near the ocean-continent boundary (present water depth: $4399 \mathrm{~m}$ ). Site 401 is located on top of a horst at the edge of the Meriadzek Terrace (present water depth: $2495 \mathrm{~m}$ ) and Hole $402 \mathrm{~A}$ on a spur of the northern continental margin of the Bay of Biscay (present water depth: $2339 \mathrm{~m}$ ). The nannoplankton assemblages of the Lower and Upper Cretaceous recovered from these holes show that, during that time, water depths are different. Lower Cretaceous sediments recovered from Site 401 and Hole 402A were deposited in marginal, near-shore conditions, as indicated by the abundance of nannoconids. They are more abundant and of larger size in the limestones from the lower Aptian (Chiastozygus litterarius Zone) in Hole 402A, Cores 34 and 35. They occur with Conusphaera mexicana, Micrantholithus obtusus, and M. holschulzi; Braarudosphaera bigelowi is abundant in Sample 34-1, $30-31 \mathrm{~cm}$. This assemblage is typical for marginal conditions (Thierstein, 1976). It is also described from Lower Cretaceous sediments of France by Bouché (1965). In contrast, coccoliths are generally less abundant and smaller, an observation made by Noël (1968) in describing an alternation of limestones and marls. The limestones are characterized by abundant nannoconids and few coccoliths, whereas coccoliths are more abundant and dominant in the marls. It is considered that the nannoconids prefer clean water without an input of terrigenous material. That nannoconids are typical of marginal environments is confirmed by investigations of several samples from Hole 398D (Leg 47, Müller, unpublished data) where nannoconids are absent. They occur only in layers that were displaced from the shelf and upper slope.

Major differences exist between the nannoplankton assemblages of the Parhabdolithus angustus Zone recovered in Hole 400A on one hand and Site 401 and Hole $402 \mathrm{~A}$ on the other. The nannoplankton assemblage in Hole 400A (located in deeper water further from the continent) contains abundant coccoliths and related nannofossils; it is dominated by species of Watznaueria and Parhabdolithus. Nannoconids are essentially absent; only in one or two samples were few specimens of Nannoconus truitti and $N$. minutus observed. In contrast, the assemblage of the $P$. angustus Zone at Site 401 and Hole 402A, located on the margins, is distinguished by the occurrence of nannoconids. At Site 401 only a few centimeters of limestone (Sample $19-1,128 \mathrm{~cm}$ ) represent this stratigraphic interval.

The assemblage and the size of the nannoconids in the limestone at Site 401 are comparable with those of the limestones from Hole 402A, but the nannoconids in the marls of the $P$. angustus Zone at Hole $402 \mathrm{~A}$, which are in general rich in detrital material, are smaller and are represented only by $N$. truitti and $N$. minutus. These species are abundant in several layers, but are present in all samples of this sequence. This observation may confirm the assumption (Noël, 1968) that nannoconids find optimal conditions in clean water without an input of terrigenous material. Coccoliths are more abundant in the lower part of the $P$. angustus Zone at Hole 402A, decreasing towards the top of this sequence. They also become smaller and more fragile in 
the upper part, which is typical for deposits in a very shallow environment (Müller, unpublished). In several layers of this sequence the content of nannofossils is diluted by the high input of terrigenous material.

A different environment for Hole 400A and Site 401 can be assumed also for the deposition of the Upper Cretaceous sediments. $T$. trifidus is typical of the $T$. trifidus Zone of the uppermost Campanian-lowermost Maestrichtian. It is abundant in Hole 400A but was not found at Site 401. The corresponding stratigraphic interval at Site 401 is distinguished by the abundance of Lucianorhabdus cayeuxii, which was not observed at Hole 400A. This species is considered to be typical for marginal, boreal conditions (Thierstein, 1976). However, the presence of $T$. murus in the upper Maestrichtian (a species of tropical-subtropical regions) at Site 401 indicates warmer water temperatures for the Upper Cretaceous. According to this observation the marginal conditions seem to be the more important factor in controlling the absence or presence of $L$. cayeuxii. A shallower environment for the deposition of the Upper Cretaceous sediments at Site 401 may be also confirmed by the abundance of Lithraphidites quadratus in the Maestrichtian. This species is rare at Hole $400 \mathrm{~A}$, but its scarcity cannot be explained only by dissolution. It is considered to be a nearshore, shallow-water species (Roth, in press).

\section{TERTIARY}

\section{Biostratigraphy}

Lower Paleocene sediments encompassing Chiasmolithus danicus Zone NP 3 were recovered only at Site 401 (Sample 16, CC and Sample 17, CC) in the Bay of Biscay. They are underlain by deposits of the upper Maestrichtian ( $T$. murus Zone); the lower part of the Danian is not represented. The marly chalk of Zone NP 3 is rich in poorly preserved calcareous nannofossils. The assemblage is distinguished by the abundance of Braarudosphaera bigelowi, B. discula, and Thoracosphaera deflandrei, and is very similar to the assemblage described by Hay and Mohler (1967) from the early Paleocene of Pont Labau (France). It is overlain by the upper Paleocene $H$. riedeli Zone (NP 8) and $D$. multiradiatus Zone (NP 9). This hiatus, which represents an interval of about $3 \mathrm{~m}$.y., is known from many parts of North Europe (France, North Germany, England, North Sea). The hiatus is marked further by a lithologic change from marly chalks to siliceous nannofossil oozes. The same sedimentological change at the end of the Danian is also known from the North Sea and North Europe.

Nannoplankton Zones NP 8 and NP 9 were recovered at Hole $400 \mathrm{~A}$. Here the sediments contain abundant, well-preserved to slightly etched nannofossils. The assemblages are highly diverse; discoasters are abundant, mainly in the $D$. multiradiatus Zone. Besides the typical nannoplankton assemblages of the $H$. riedeli Zone and $D$. multiradiatus Zone, other species occur which may be of stratigraphic value. Hornibrookina australis seems to be restricted to the upper Paleocene nannoplankton Zones NP 8 and NP 9. This species is described by Edwards and Perch-Nielsen (1975) in the same stratigraphic interval from the Southwest Pacific, and by Edwards (1973) as Hornibrookina sp. from the Tasmanian Sea. The northernmost occurrence of $H$. australis is mentioned by Edwards and Perch-Nielsen (1975) from the upper Paleocene of the Crimea. H. australis was also observed in the Heliolithus riedeli Zone (NP 8) of North Germany (Müller, unpublished data), and it is also present in the $D$. multiradiatus Zone (NP 9) in Hole 400A. Rhomboaster cuspis was found in several samples of Core 41 at Site 401 (D. multiradiatus Zone, NP 9), but it was not observed in Hole 400A. This species is described by Bramlette and Sullivan (1961) from the D. multiradiatus Zone of the Lodo Formation of California and by Bukry and Bramlette (1970) from the northwestern Pacific (Site 47). It is also mentioned by Bukry (1972) from Site 118 (Bay of Biscay) in a mixed assemblage of Eocene and Paleocene nannofossils. $R$. cuspis $(=R$. calcitrapa) is also described by Gartner (1971) from the $D$. multiradiatus Zone from the Blake Plateau. Locker (1968) mentioned this species from the lower Eocene, but the illustration given in his paper does not allow a precise identification. It seems that $R$. cuspis is restricted to the $D$. multiradiatus Zone. Edwards (1971) established the $R$. cuspis Zone in New Zealand, which according to its definition (interval from the first occurrence of $R$. cuspis to the first occurrence of Marthasterites tribrachiatus) would correspond to the uppermost Paleocene and lowermost part of the $M$. contortus Zone (NP 10) of the lower Eocene. It seems that $R$. cuspis is restricted to a very short time interval, at the Paleocene/Eocene boundary. Sphenolithus anarrhopus ( $=S$. conspicuus Martini, 1976) is described by Bukry and Bramlette (1969) from the upper Paleocene, and by Martini (1976) from the lower Eocene (nannoplankton Zones NP 11 and 12). This species was found in the Bay of Biscay in the $D$. multiradiatus Zone (NP 9) to the $M$. tribrachiatus Zone (NP 12). It is also known from lower Eocene sediments (NP 11 and NP 12) in North Germany and Italy (Müller, unpublished data). The upper Paleocene sediments, determined by dinoflagellates (see: Costa and Downie, this volume) at Sites 403 and 404 from the Rockall Plateau, are barren of nannofossils. The lower Eocene sequence recovered in the Bay of Biscay is condensed as compared with those from the margins of the Rockall Plateau where the lower Eocene is very thick. At Sites 403 and 404 the high amount of terrigenous and volcaniclastic material and at Site 405 the high production of siliceous and calcareous microfossils account for this. The nannoplankton assemblages of the lowermost Eocene $(M$. contortus Zone, NP 10) from the Bay of Biscay and the Rockall Plateau are not comparable due to the different environments of deposition. $M$. contortus, the index fossil for the zone, was not found although a few specimens of $M$. bramlettei occur at Sites 403 and 404; this species is not present in the lowermost Eocene sediments of the Bay of Biscay.

The upper Paleocene-lower Eocene ash layers encountered in the holes drilled on the margin of the Rockall Plateau (Site 403 and 404) probably correspond to those known from the same stratigraphic interval in northwestern Europe and the North Sea. Until now it has not been possible to determine the $M$. contortus Zone (NP 10) in northwestern Europe where sediments of this age are characterized by the occurrence of ash layers and the absence of calcareous microfossils (Bettenstaedt et al., 1962). Moorkens (1976) suggested that the absence of 
calcareous microfossils was due to dissolution. The sediments of the $M$. contortus Zone (NP 10) and the $D$. binodosus Zone (NP 11) at Sites 403 and 404 are poor in nannofossils. They are slightly more abundant in the sediments at Site 404 where the sediments appear to have been deposited in a slightly deeper environment (Peypouquet, this volume). The nannoplankton assemblages consist mainly of Koczyia fimbriata, Transversopontis pulcher, Toweius eminens, $T$. craticulus, Zygolithus dubius, C. bidens, Zygodiscus plectopons, Ellipsolithus macellus, Discoasteroides kuepperi, $M$. tribrachiatus, Imperiaster obscurus, and Neochiastozygus junctus. Discoasters are rare. I. obscurus, which becomes abundant in several samples of the lower Eocene in Holes 403 and 404 , was not found in the sediments of the same age in the Bay of Biscay. Few specimens of this species are present in the Discoaster lodoensis Zone (NP 13) at Site 405. This was also observed in North Germany (Müller, unpublished). I. obscurus is described by Martini (1970) only from the $D$. binodosus Zone (NP 11) and the $M$. tribrachiatus Zone (NP 12). According to the results from Leg 48 and North Germany, this species seems to have a longer range in several areas, which may be controlled by ecological factors. However, further investigations are necessary to confirm this assumption. The reddish brown calcareous marls recovered in the Bay of Biscay in the lower Eocene (nannoplankton Zones NP 11 and NP 12) have a wide geographic distribution. They are also known from North Germany, England, Denmark, France, and the North Sea in the same stratigraphic interval (Bettenstaedt et al., 1967; Perch-Nielsen, 1967). Rhabdolithus solus is described by Perch-Nielsen (1971) from the lower Eocene of Denmark. This species also occurs within this zone in the Bay of Biscay and the Rockall Plateau as well as in North Germany and Austria (Müller, unpublished data). According to results from Hole $400 \mathrm{~A}$, it first occurs in the uppermost Paleocene.

Cyclococcolithus gammation, described by Bramlette and Sullivan (1961), appears to be restricted to the $D$. lodoensis Zone (NP 13) and the D. sublodoensis Zone (NP 14). Martini (1976) also records it only from the nannoplankton Zone NP 14. In the material from Leg 48 the species occurs in nannoplankton Zones NP 13 and NP 14, but is never abundant. Rhabdosphaera inflata was found only in the $D$. sublodoensis Zone (NP 14) in the Bay of Biscay and the Rockall Plateau. It is present also in the nannoplankton Zone NP 14 of Pakistan and Columbia (Müller, unpublished), and is described by Bramlette and Sullivan (1961) from Unit 5 (= Zone NP 14) of the Lodo Formation of California. Bukry and Kennedy (1969) described $R$. inflata from the Rose Canyon Shale Member of the La Jolla Formation, which also belongs to Zone NP 14; Bukry (1972) reports it from the Zone NP 14 of the Bay of Biscay. According to these results $R$. inflata has a restricted occurrence within the lowermost middle Eocene and is of considerable stratigraphic value. It was not observed in sediments of the $D$. sublodoensis Zone (NP 14) in Site 406 on the Rockall Plateau and in North Germany. Its presence within the D. tani nodifer Zone (NP 16) of the middle Eocene in Italy reported by Proto Decima et al. (1975) is probably caused by reworking. This is also observed in the uppermost middle
Eocene/lowermost upper Eocene of Austria (Müller, unpublished data), where a few specimens of it occur along with many reworked species of Paleocene to middle Eocene ages.

Large specimens of Reticulofenestra umbilica are present in the D. sublodoensis Zone (NP 14). Its first occurrence is in the Chiphragmalithus alatus Zone (NP 15), and smaller, round specimens similar to $R$. umbilica are found as low as the $D$. lodoensis Zone (NP 13).

A few specimens of $D$. septemradiatus and $D$. nonaradiatus, which have a range from the upper part of the $D$. lodoensis Zone (NP 13) to the lower part of the $C$. alatus Zone (NP 15) are present in almost all samples of the $D$. sublodoensis Zone (NP 14).

Complexly structured nannofossils (Plate 8, Figures 1 to 6) are present in Section 404-7-1. Comparable specimens are described by Perch-Nielsen (1971) from the lower Eocene of Denmark; they have been also observed in several samples of this stratigraphic interval in north Germany (Müller, unpublished data).

A few specimens of $D$. martinii are present in almost all samples of the $C$. alatus Zone (NP 15). It appears to be typical of the zone, but is never abundant. D. martinii is reported by Martini (1958) as ' $D$ pentaradiatus" from sediments from the nannoplankton Zone NP 15 in North Germany, and it is known in the same stratigraphic interval from several wells of North Germany (Müller, unpublished data). It is also described by Bramlette and Sullivan (1961) and by Bukry (1972) from the same zone. Chiasmolithus gigas appears restricted to the lower part of the Chiphragmalithus alatus Zone (NP 15). The boundary between the C. alatus Zone and the D. tani nodifer Zone (NP 15/NP 16) is sometimes not possible to establish because of the absence of Rhabdosphaera gladius; this species seems to be absent in pelagic sediments. It is proposed to use the first appearance of $D$. tani nodifer for the determination of Zone NP 16.

Cribrocentrum reticulatum first occurs in the upper part of Zone NP 16 and becomes abundant in the upper Eocene. It has not been reported in lower Oligocene sediments, and its disappearance can be used to determine the Eocene/ Oligocene boundary in regions where discoasters are rare or missing in the uppermost Eocene such as North Germany, Austria, northern and southern high latitudes (Müller, unpublished data).

S. obtusus, as described by Bukry (1971), has its first occurrence in the upper part of the D. tani nodifer Zone (NP 16) and is present in the D. saipanensis (NP 17) and Chiasmolithus oamaruensis (NP 18) Zones. It is also reported by Martini (1976) from the Pacific Ocean within this stratigraphic interval. Helicosphaera dinesenii $(=H$. heezeni Bukry, 1971) is present mainly in Zones NP 16 and NP 17. S. orphanknolli $(=S$. spininger Bukry, 1971) has its maximum development in the middle Eocene (NP 15/NP 16). Corannulus germanicus, Clathrolithus ellipticus, and Bramletteius serraculoides seem to be typical of the upper Eocene, mainly in the D. saipanensis Zone. These species were found along with Braarudosphaera bigelowi, Pemma rotundum, and Micrantholithus basquensis in the upper Eocene sediments of Hole 402A in the Bay of Biscay, which are deposited in marginal conditions. The range of $S$. 
pseudoradians is known from tropical areas from the middle Eocene (NP 16) to the middle Oligocene (NP 24). It was not found in the material of Leg 48, but it is reported by Perch-Nielsen (1972) from the North Atlantic.

A significant transgression can be assumed during the upper part of the middle Oligocene $(S$. distentus Zone, NP 24). Sediments of this stratigraphic interval have a wide geographic distribution and in general are rich in nannofossils, the assemblages being distinguished by low species diversity. It is the only time during which nannofossil ooze is deposited in the Norwegian-Greenland Sea (north and south of the Faeroe-Iceland Ridge and on the Vøring Plateau), and is interpreted as a northward penetration of Atlantic water masses (Müller, 1976); nannoplankton assemblages of this zone are the same in both the Rockall Plateau area and the North Atlantic (Perch-Nielsen, 1972; Bukry, 1972). The nannofossils of the upper part of the middle Oligocene are remarkably larger than those of upper Oligocene to lower Miocene sediments, where they are often extremely small; this also has been observed in the Mediterranean (Bizon and Müller, 1978).

Isthmolithus recurvus is generally considered to have its last occurrence in the early Oligocene, but a few specimens have been found in the lower part of the middle Oligocene in North Germany and in the Netherlands (Benedek and Müller, 1976). It is also described by Edwards and Perch-Nielsen (1975) from southern high latitudes. The same is true for Chiasmolithus oamaruensis, which persists into middle Oligocene sediments on the margin of the Rockall Plateau.

Subdivision of the middle/upper Oligocene $(S$, distentus/S, ciperoensis zones, NP 24/NP 25) is often impossible because of the absence or scarcity of sphenoliths. In addition, $T$. carinatus, which can be a useful zone marker, was observed only at Site 406; few specimens occur at Site 403.

Determination of the Oligocene/Miocene boundary is difficult. The boundary is defined by the extinction of $H$. recta which is absent or rare in the upper Oligocene sediments recovered during Leg 48. Dissolution, which was significant at this time, may be a partial cause. The Oligocene/Miocene boundary is herein determined by the last occurrence of Dictyococcites dictyodus and Zygrhablithus bijugatus; $D$. dictyodus is rare in the uppermost Oligocene. The range of the most important species is given in Table 20

\section{NEOGENE}

It is difficult to distinguish the Neogene nannofossil zones according to the standard zonation of Martini (1971) because some index fossils are absent or scarce. This paucity reflects decreasing water temperatures that began in late Eocene time in the high latitudes, and continued into the Neogene.

The lower Miocene zones in Hole 400A and at Site 406 are obscure, particularly the $T$. carinatus Zone (NN 1) and the Discoaster druggii Zone (NN 2). The S. belemnos Zone (NN 3) is determined in Hole 400A by the presence of that species. H. ampliaperta, which is normally present in high latitudes, is absent or, at Hole 400A and Site 406, rare. This may be due to dissolution of calcareous microfossils in lower Miocene sediments; helicospheres are not very resistant to dissolution. $S$. heteromorphus is present in both regions, possibly as a result of widespread transgression and northward penetration of Atlantic water masses. The interval of the $H$. ampliaperta Zone (NN 4) and $S$. heteromorphus Zone (NN 5) is the only one that can be determined in northern Europe (Martini and Müller, 1973). The interval corresponds to the Hemmoor transgression in North Germany.

The $D$. exilis Zone (NN 6) of the middle Miocene is recognized by the presence of $D$. exilis and Cyclicargolithus abisectus; $D$. exilis is generally abundant. Another species in this zone is Coronocyclus cf. C. nitescens (oval) which is present in the same stratigraphic interval from the Paratethys and the Mediterranean (Müller, 1974b, 1977), $T$. rugosus is abundant in several samples of the $D$. exilis Zone (NN 6). A few specimens of $S$. heteromorphus exist in the D. exilis Zone and D. kugleri Zone (NN 7), as they do in the Paratethys (Rögl and Müller, 1976). D. kugleri is rare in the middle Miocene sediments at Hole 400A, and only one specimen of Catinaster coalitus was found in Core 27 at this site.

The determination of the upper middle Miocene nannoplankton Zones NN 8, NN 9 and lower NN 10 is not possible because index fossils are missing. Discoasters are few in the interval or are strongly overgrown. The same holds true for the Mediterranean (Bizon and Müller, 1977). Inability to determine the zones of this stratigraphic interval does not necessarily imply a hiatus. The large variety of Coccolithus pelagicus $(=C$. miopelagicus Bukry, 1971) is common in nannoplankton Zones NN 6 and NN 7, and seems to be a useful indicator for the middle Miocene, at least in the North Atlantic.

The $D$. quinqueramus Zone (NN 11) of the upper Miocene is generally thick, being about 60 meters in Hole $400 \mathrm{~A}$, about 160 meters at Site 403 , about 90 meters at Site 404 , and about 200 meters at Site 406 . D. quinqueramus is scarce in almost all samples; in some layers it is missing. The species is mainly represented by the smaller variety of $D$. quinqueramus with the shorter arms $(=D$. berggrenii Bukry, 1971). D. calcaris is more abundant and seems to have been less sensitive to changing water temperatures. Fluctuations of water temperature during late Miocene is evidenced by variable abundance of discoasters and variable degrees of dissolution. Ceratolithus tricorniculatus occurs in almost all samples of the $D$. quinqueramus Zone and in the lower part of the $C$. tricorniculatus Zone (NN 12) in the Bay of Biscay, whereas it and $S$. abies are less frequent further north.

Pliocene nannoplankton zones are also difficult to determine for lack of index fossils. Decreasing water temperatures continued into the Pliocene, becoming most evident in the upper Pliocene where discoasters are absent. Slightly warmer water temperatures are suggested at the base of the Pliocene and in nannoplankton Zone NN 15 (lower part). The $C$. tricorniculatus Zone (NN 12) is combined with the $C$. rugosus Zone (NN 13) because $C$. rugosus occurs only sporadically or is missing. The base of the $D$. asymmetricus Zone (NN 14) is determined by the 
first occurrence of $D$. asymmetricus. Discoasters are rare to absent in the lower Pliocene sediments. The $D$. asymmetricus Zone (NN 14) and the Reticulofenestra umbilica Zone (NN 15) are combined because $C$. tricorniculatus, the extinction of which is used to distinguish the boundary between these zones, is missing in the upper part of the lower Pliocene; $C$. tricorniculatus has an earlier extinction in high latitudes. Small specimens of $R$. pseudoumbilica occur in the upper part of Zone NN 15, although they are larger further down in the zone. This also occurs in the Mediterranean (Müller, 1978), and may be related to decreasing water temperatures after a slight warming in the lower part of the R. pseudoumbilica Zone. An overlap of $R$. pseudoumbilica and Pseudoemiliania lacunosa (smaller, oval) can be observed in the uppermost part of this zone. It too is reported from the Mediterranean (Müller, 1978). S. abies is uncommon throughout the lower Pliocene.

Subdivision of the upper Pliocene is impossible because discoasters are absent, probably from the uppermost part of the $D$. surculus Zone (NN 16) to the top of the Pliocene $(D$. brouweri Zone, NN 18). The D. pentaradiatus Zone (NN 17 ) and the $D$. brouweri Zone (NN 18) are therefore combined and include the interval from the last occurrence of D. surculus to the last occurrence of Cyclococcolithus macintyrei.

The Pliocene/Pleistocene boundary is marked by the extinction of $C$. macintyrei, which occurs near the top of the Olduvai event according to paleomagnetic measurements at Hole 400A (Hailwood, this volume). The extinction of $C$. macintyrei coincides with the extinction level of $D$. brouweri, also near the top of the Olduvai event as determined in several areas (Berggren et al., 1969; Gartner, 1971; Cita et al., 1973; Ryan et al., 1974; Gartner, 1971). The extinction of $C$. macintyrei was also used in the western Mediterranean to determine the Pliocene/Pleistocene boundary (Müller, 1978; Bizon and Müller, 1977, 1978). A small and primitive species of Gephyrocapsa (probably $G$. aperta) is present in the uppermost Pliocene. The lower Pleistocene ( $P$. lacunosa Zone, NN 19) is distinguished by the abundance of Discolithina japonica and $P$. pacifica. Both species are rare or absent in both upper Pliocene and upper Pleistocene. Pseudoemiliania lacunosa is a somewhat smaller form than specimens from subtropical regions. $G$. oceanica is represented by a smaller variety which is abundant in the Pleistocene sediments of the Bay of Biscay and the Rockall Plateau. In some layers it and Coccolithus pelagicus are the only nannoplankton species. Large specimens of Emiliania huxleyi, which is typical of cooler water masses (McIntyre and Bé, 1967) are abundant in the E. huxleyi Zone (NN 21) at Site 406.

The nannoplankton assemblage of the Quaternary (typical for the transitional zone [McIntyre and Bé, 1967]) contains abundant $C$. pelagicus, Cyclococcolithus leptoporus, Gephyrocapsa sp. (small), E. huxleyi, Syracosphaera pulchra, and $H$. carteri.

Ice-rafted material first appears in the upper Pliocene; it contains reworked species of Cretaceous and Eocene ages. Autochthonous nannofossils are rare in these beds, which is typical for the North Atlantic (Perch-Nielsen, 1972;
Martini, in press) and the Norwegian-Greenland Sea (Müller, 1976).

\section{PALEOECOLOGY}

The location of Leg 48 drilling sites in different water depths and in different latitudes permits some paleoecological interpretations for the distribution of several nannofossils. The marginal conditions assumed for the deposition of the Upper Cretaceous sediments at Site 401 continued into early Paleocene time (Chiasmolithus danicus Zone, NP 3). The nannoplankton assemblage is distinguished by the abundance of Braarudosphaera bigelowi and $B$. discula, Micrantholithus pinguis is less abundant, but the sediments are rich in Thoracosphaera deflandrei. Thierstein and $\mathrm{Haq}$ (1977) described B. bigelowi and $B$. discula as typical near-shore species, whereas thoracospheres are considered to be open-ocean indicators. This conclusion is not confirmed by the results obtained from Site 401. Thoracospheres seem to be more influenced by water temperatures; they are abundant in tropical and subtropical regions, and almost absent in temperate and high latitude areas. The presence of Rhomboaster cuspis in the upper Paleocene (Discoaster multiradiatus Zone, NP 9) at Site 401 and its absence in the sediments in Hole 400A, which were deposited in an open-ocean deep-water environment, may indicate that this species prefers marginal conditions. $R$. cuspis is described from only a few regions and it is difficult to recognize the factors which control its absence or presence. It is described by Bramlette and Sullivan (1961) from the Lodo Formation, California, considered by Sullivan (1965) to be littoral deposits. This can also be assumed for the lower part of the Wanstead Formation, New Zealand (Edwards, 1971). Bukry (1972) found $R$. cuspis in a mixed assemblage of Paleocene and lower Eocene nannofossils in the Bay of Biscay (Site 118). It is possible that the Paleocene species are reworked from the slope.

Hornibrookina australis of the upper Paleocene (nannoplankton Zones NP 8 and NP 9) is known from southern and northern high latitudes, the Bay of Biscay, and North Germany, but is not reported from tropical and subtropical regions; probably this species prefers lower water temperatures, but it is a small species and easy to overlook.

Early Eocene assemblages from the Bay of Biscay and the margins of Rockall Plateau are different due to the position of the sediments in totally different environments. Their scarcity and their smaller size in the lowermost Eocene (Marthasterites contortus Zone, NP 10) at Sites 403 and 404 indicate deposition in very shallow water, which is confirmed by ostracodes (Peypouquet, this volume) and benthic foraminifers (Murray, this volume). Investigation of Pleistocene sediments from cores which were taken in shallow water $(0$ to $50 \mathrm{~m})$ has shown that nannofossils therein are either absent or extremely rare, of smaller size, and more fragile than in sediments deposited in deeper water. In water depths of 60 meters and deeper, nannofossils are abundant (Müller, unpublished data). The maximal distribution in modern temperate to tropical areas lies between 50 and 100 meters depth, and in the uppermost 
50 meters of the water column in subarctic regions (Honjo, 1976).

The assemblage of the $M$. contortus Zone at Sites 403 and 404 is distinguished by the occurrence of Zygodiscus plectopons and $M$. bramlettei. $M$. bramlettei seems to prefer a near-shore, shallow environment. Nannofossils are more abundant and the assemblages more diversified in the sediments of the $D$. binodosus Zone (NP 11) and $M$. tribrachiatus Zone (NP 12) at both sites, indicating subsidence during the Eocene. The assemblages are typical of an epicontinental environment and they are comparable with those described from the Norwegian-Greenland Sea (Müller, 1976) and northwest Europe (Martini, 1958; Locker, 1968; Perch-Nielsen, 1972; Müller, unpublished). Imperiaster obscurus, Koczyia fimbriata, Micrantholithus mirabilis, and abundant Zygolithus dubius are characteristic for this assemblage. I. obscurus is known from North Germany, Belgium, Denmark, Siberia, and England (Martini, 1970; Perch-Nielsen, 1968; Bukry, 1972). It is also described from Hole 117A on the Rockall Plateau (Bukry, 1972) and from the Norwegian-Greenland Sea (Müller, 1976). M. mirabilis is known from north Germany (Locker, 1968); Denmark (Perch-Nielsen, 1968); and from the Norwegian-Greenland Sea (Müller, 1976). Neither species was observed in the sediments of the Bay of Biscay, which were deposited in a deeper environment (Peypouquet, this volume, and Schnitker, this volume). From these results it seems very likely that the presence or absence of $I$. obscurus and $M$. mirabilis are more controlled by depth than by water temperatures.

The presence of $I$. obscurus and the abundance of Zygrhablithus bijugatus, Zygolithus dubius, and Transversopontis pulcher in the lower Eocene sediments (nannoplankton Zone NP 12) indicate marginal, near-shore conditions; the ostracodes in this zone support an upper bathyal to middle bathyal environment of about 300 to 1000 meters (Peypouquet, this volume).

Rhabdosphaera gladius in the middle Eocene sediments, Zone NP 15, seems also to be contrclled by ecological factors. This species is present in the epicontinental sediments of northwest Europe where it is abundant in several layers along with other species of Rhabdosphaera. It is missing, however, in the middle Eocene sediments recovered in the Bay of Biscay at Hole 400A. Bukry (1972) did not report it from the Bay of Biscay, and it is also absent in the pelagic middle Eocene sediments from the central Pacific Ocean (Martini, 1976) and from the Indian Ocean (Müller, 1974).

A few specimens of $R$. gladius occur at Site 401 and some reworked specimens in the upper Eocene sediments from Hole 402A. The scarcity or absence of $R$. gladius due to ecological conditions diminish the value of this species as an index fossil. In contrast Chiphragmelithus alatus occurs in almost all samples from this stratigraphic interval.

Marginal conditions for the deposition of the upper Eocene sediments (Zone NP 19) at Hole 402A are shown by the presence of Bramletteius serraculoides along with numerous Braarudosphaera bigelowi, $M$. basquensis, Pemma rotundum, $M$. procerus, $R$. tenuis, and $R$. spinula and few specimens of Corannulus germanicus and Clathrolithus ellipticus.
Latitudinal differentiation of the nannoplankton assemblages existed through Eocene time. They are less distinct or not recognizable during the Neogene when the assemblages found in the Bay of Biscay were comparable with those from the margins of the Rockall Plateau. Several groups of nannofossils, such as discoasters, sphenoliths, scyphosphere, thoracospheres, and ceratoliths, are considered to indicate warmer water temperatures. Based on this, an attempt was made to recognize changing water temperatures during the Tertiary in the North Atlantic. Varying degrees of dissolution caused by fluctuations of the CCD were taken also into consideration.

The abundance of $D$. multiradiatus in the upper Paleocene/lowermost Eocene of the Bay of Biscay indicates warmer water temperatures. Discoasters are less frequent at Sites 403 and 404 drilled on the margins of the Rockall Plateau. This may be due to latitudinal differentiation or to the deposition of these sediments in a shallow environment. However, discoasters were also rare in North Germany at this time (Müller, unpublished). Cooler water temperatures can be discerned for Zone NP 11 and the lower part of NP 12 by the paucity of discoasters. This interval was followed by a short warming period, represented by the upper part of Zone NP 12 and in Zone NP 13, which is more distinct in the Bay of Biscay. Rarity of discoasters in the sediments of this interval on Rockall Plateau indicates cooler water temperatures there.

A slight decrease of water temperature in the lower part of the D. sublodoensis Zone (NP 14) was followed by an increase in the upper part of the zone. The middle Eocene NP 15 and NP 16 zones indicate slightly lower water temperature which again increased in Zone NP 17 of the upper Eocene. Lower temperatures can be observed again towards the top of the Eocene (Zones NP 19 and NP 20); this decrease is more distinct in higher latitudes (Rockall Plateau, Site 406, and northern Europe), where discoasters are rare or missing in the uppermost Eocene. They are common in the sediments of the same stratigraphic interval in the Bay of Biscay.

Latitudinal differentiation of the nannoplankton assemblages continued during Oligocene time. Sphenolithus distentus and $S$. predistentus are present in middle Oligocene sediments from the Bay of Biscay (washed interval at Site 401), but are missing or extremely rare in the middle Oligocene sediments from the margin of the Rockall Plateau, as they are from land sections. Sphenoliths are present in the middle Oligocene of the Mediterranean area, southwest France, and the Rhinegraben (Müller, 1971), but they are absent in North Germany and Belgium. A general characteristic of the Oligocene nannoplankton assemblage is a species diversity lower than that from the middle-late Eocene. This is not restricted to the North Atlantic, but is also known from the Indian Ocean and the Pacific, and suggests a worldwide cooling during Oligocene time.

Nannoplankton assemblages of the middle Oligocene (Zone NP 23 and mainly, Zone 24) are comparable with those described from other sites drilled in the North Atlantic (DSDP Leg 12) and from the Norwegian-Greenland Sea (DSDP Leg 38). The interval is characterized by the occurrence of Chiasmolithus altus and $D$. deflandrei both of which are missing in the middle Oligocene from North 
Germany. Coccoliths of this interval are large compared to those from upper Oligocene and lower Miocene sediments, a phenomenon also observed in North Germany (Müller, unpublished) and in the Mediterranean area (Bizon and Müller, 1977). The interval nannoplankton Zone NP 24/NP 25 is the only one during which nannofossil ooze was deposited in the Norwegian-Greenland Sea (south and north of the Iceland-Faeroe Ridge and on the Vøring Plateau). This is explained by a northward penetration of Atlantic water masses (Müller, 1976) with coincides with a significant transgression in northwest Europe.

The great abundance of Reticulofenestra in the Norwegian-Greenland Sea and northwest Europe can probably be explained by cold water. These species are less abundant in several parts of the North Atlantic, which were influenced during the middle Oligocene by warmer currents, much like the modern Gulf Stream. S. ciperoensis of the upper Oligocene was not found in the Bay of Biscay or on the Rockall Plateau, but is reported by Bukry (1972) from Site 117 drilled in the Hatton-Rockall Basin. Triquetrorhabdulus carinatus is missing in the Bay of Biscay, and also in the Mediterranean area (Müller, 1978) but is present at Site 406 and few specimens at Site 403. The presence of these species, which prefer warmer water temperatures in several areas of the North Atlantic, may confirm the assumption of warmer water masses penetrating at this time further to the north.

Cooling water temperatures can be interpreted for the lowermost Miocene (Zones NN 1 to NN 2/3). The assemblages of this interval are dominated by small specimens of Coccolithus pelagicus. Index fossils used in tropical and subtropical areas for the determination of zone boundaries occur only sporadically or are missing. It is thus difficult to make a precise age determination for the lower Miocene.

S. belemnos is present at Hole 400A in the Bay of Biscay, indicating Zone $\mathrm{NN} 3$; this interval was not recovered on the margin of the Rockall Plateau. Warmer water temperatures are assumed for the nannoplankton Zones NN 4 to NN 6, followed by a pronounced cooling, mainly in Zones NN 8 to lower NN 10. This warming in the lower-middle Miocene is again related to a transgression corresponding to the Hemmoor transgression in North Germany; it is the only stratigraphic interval in northern Europe that can be dated precisely by nannofossils (Martini and Müller, 1973) and is based on the occurrence of Helicosphaera ampliaperta and $S$. heteromorphus.

D. exilis is in general abundant within Zone NN 6. The species seems to have been less sensitive to changing water temperatures. Discoasters are fewer in the $D$. kugleri Zone (NN 7) and are rare to absent in Zones NN 8 and NN 9. Catinaster coalitus, the index fossil of Zone NN 8 is absent. The determination of these zones is thus almost impossible, as is the case in the Mediterranean area (Bizon and Müller, 1978, Müller, 1978); a hiatus is not necessarily implied. Pronounced cooling, with a maximum at about $11 \mathrm{~m} . \mathrm{y}$. (Bizon and Müller,1977), is confirmed by isotopic measurements (Grazzini et al., this volume). Slightly increased water temperatures are assumed for the middle part of the D. calcaris Zone (NN 10), but they decreased, with several fluctuations, during the upper Miocene $(D$. quinqueramus Zone, NN 11). These fluctuations are interpreted on the presence or absence of discoasters, Ceratolithus tricorniculatus and differences in the degree of dissolution.

D. calcaris appears to have been less sensitive to changing water temperatures than was $D$. quinqueramus. The latter species is rare or missing in several layers in which $D$. calcaris is still present. In general the nannoplankton assemblages of the upper Miocene are distinguished by low species diversity. The assemblage consists mainly of long ranging species like Coccolithus pelagicus, $R$. pseudoumbilica, $C$. macintyrei and $C$. leptoporus. The scarcity of $H$. carteri is probably due to dissolution, because helicospheres are not dissolution resistant.

Discoasters and Ceratolithus tricorniculatus become more abundant in the lower part of the $C$. tricorniculatus Zone (NN 12) at the Miocene/Pliocene boundary and in the lowermost Pliocene, indicating a slight warming at this time, which is confirmed by isotopic measurements (Grazzini et al., this volume). Specimens of $D$. pentaradiatus are represented by the smaller variety with small bifurcations at the end of the rays. This variety occurs also in the lowermost Pliocene of the western Mediterranean, whereas in the eastern Mediterranean the large variety is present (Müller, 1978). Another slight warming is interpreted in the $R$. pseudoumbilica Zone (NN 15 ) of the uppermost lower Pliocene, as is indicated by the presence of some scyphospheres and a larger number of discoasters.

Lower water temperatures dominate again during the upper Pliocene with a major drop in the uppermost part of the $D$. surculus Zone (NN 16) to the $D$. brouweri Zone (NN 18). This lowering, at about $2.7-2.5$ m.y., relates in the North Atlantic with the first occurrence of ice-rafted material (Berggren, 1972; Müller, this volume) and is indicated by the almost complete disappearance of discoasters; the Pliocene/Pleistocene boundary is determined by the extinction of Cyclococcolithus macintyrei (Müller, 1978; Bizon and Müller, 1977, 1978). In the Mediterranean, mainly in the western part, the scarcity or absence of discoasters at the same level (Bukry, 1973; Müller, 1978), records a coincident cooling.

Fluctuations of water temperatures during the Quaternary (mainly in the upper part, Zones NN 20 and NN 21) are indicated by alternation of sediments rich in nannofossils and with those containing abundant reworked Cretaceous and Eocene species. Intercalations of sediments rich in reworked species and ice-rafted material were also mentioned by Perch-Nielsen (1972) and Martini (in press) from other sites drilled in the North Atlantic, and by Müller (1976) from the Norwegian-Greenland Sea. The abundance of Discolithina japonica and Pontosphaera pacifica in the Pseudoemiliania lacunosa Zone (NN 19) in the North Atlantic may be typical of cooler water temperatures but their abundance was not observed from other regions by the author. 


\section{SYSTEMATIC PALEONTOLOGY}

Genus SCYPHOSPHAERA sp. Lohmann, 1902

Scyphosphaera sp.

(Plate 8, Figures 10-12; Plate 9, Figure 15)

Remarks: Scyphosphaera sp. has a conical, flat dish-like shape, with a circular proximal plate without pores. The wall consists of about 40 slightly turned elements, which form a rim on the distal side. Several specimens were found in the lower Eocene (Discoaster lodoensis Zone, NP 13) at Site 405 .

\section{Incertae sedis}

Genus NANNOTURBA n. gen.

Definition: Forms consisting of several sticks or plates of rectangular to quadratic shape.

\section{Nannoturba robusta $n$. sp. (Plate 8, Figures 4-6)}

Description: This species is constructed of rectangular to quadratic sticks which are combined at an angle of $90^{\circ}$.

Diameter: 8.5-9.0 $\mu \mathrm{m}$.

Holotype: Plate 8, Figure 4, S.MB 13017.

Paratype: Plate 8, Figure 5, S.MB 13018.

Type locality: DSDP Site 404, Core 7-1, 13-14 cm.

Type level: Discoaster lodoensis Zone (NP 13), lower Eocene.

Distribution: These forms are described by Perch-Nielsen (1971) from the lower Eocene of Denmark as calcite crystals. They are also observed in lower Eocene sediments of north Germany (Müller, unpublished data) and Poland (Martini, personal communication).

\section{Nannoturba spinosa n. sp.}

$$
\text { (Plate 8, Figures 1-3) }
$$

Description: Nannoturba spinosa is hexagonal in shape, constructed of rectangular plates which are combined at an angle of $120^{\circ}$. Four of these elements are interlaced at the ends.

Remarks: The species differs from Nannoturba robusta by its shape and arrangement of the elements.

Diameter: $10-12 \mu \mathrm{m}$.

Holotype: Plate 8, Figure 3, S.MB 13019.

Paratype: Plate 8, Figure 1, S.MB 13020.

Type locality: DSDP Site 404, Core 7-1, $13-14 \mathrm{~cm}$.

Type level:Discoaster lodoensis Zone (NP 13), lower Eocene.

Distribution: Nannoturba spinosa was found until now only in the lower Eocene of the North Atlantic.

\section{LIST OF SPECIES MENTIONED IN THIS REPORT}

Blackites creber (Deflandre) Roth, 1970

Braarudosphaera bigelowi (Gran and Braarud) Deflandre, 1947

Braarudosphaera discula Bramlette and Riedel, 1954

Bramletteius serraculoides Gartner, 1969

Campylosphaera dela (Bramlette and Sullivan) Hay and Mohler, 1967

Catinaster coalitus Martini and Bramlette, 1963

Ceratolithus rugosus Bukry and Bramlette, 1968

Ceratolithus tricorniculatus Gartner, 1967

Chiasmolithus altus Bukry and Percival, 1971

Chiasmolithus bidens (Bramlette and Sullivan) Hay and Mohler, 1967

Chiasmolithus danicus (Brotzen) Hay and Mohler, 1967

Chiasmolithus gigas (Bramlette and Sullivan) Radomski, 1968

Chiasmolithus grandis (Bramlette and Riedel) Radomski, 1968

Chiasmolithus titus Gartner, 1970

Chiasmolithus oamaruensis (Deflandre) Hay, Mohler, and Wade, 1966

Chiasmolithus solitus (Bramlette and Sullivan) Locker, 1968

Chiphragmalithus alatus (Martini) Martini, 1969

Chiphragmalithus cristatus (Martini) Bramlette and Sullivan, 1961

Clathrolithus ellipticus Deflandre, 1954

Coccolithus eopelagicus (Bramlette and Riedel) Bramlette and Sullivan, 1961
Coccolithus helis Stradner, 1963

Coccolithus miopelagicus Bukry, 1971

Coccolithus pelagicus (Wallich) Schiller, 1930

Coccolithus staurion (Bramlette and Sullivan) Gartner, 1971

Corannulus germanicus Stradner, 1962

Coronocyclus nitescens (Kamptner) Bramlette and Wilcoxon, 1967

Coronocyclus serratus Hay, Mohler and Wade, 1966

Crenalithus doronicoides (Black and Barnes)

Cribrocentrum reticulatum (Gartner and Smith) Perch-Nielsen, 1971

Cruciplacolithus tenuis (Stradner) Hay and Mohler, 1967

Cyclicargolithus floridamus (Roth and Hay) Bukry, 1971

Cyclococcolithus formosus Kamptner, 1963

Cyclococcolithus gammation (Bramlette and Sullivan) Sullivan, 1964

Cyclococcolithus leptoporus (Murray and Blackman) Kamptner, 1954

Cyclococcolithus luminis Sullivan, 1965

Cyclococcolithus macintyrei Bukry and Bramlette, 1969

Cyclococcolithus rotula Kamptner, 1956

Dictyococcites dictyodus (Deflandre and Fert) Martini, 1969

Discoaster asymmetricus Gartner, 1969

Discoaster barbadiensis Tan Sin Hok, 1927

Discoaster binodosus Martini, 1958

Discoaster brouweri Tan Sin Hok, 1927

Discoaster calcaris Gartner, 1967

Discoaster challengeri Bramlette and Riedel, 1954

Discoaster cruciformis Martini, 1958

Discoaster deflandrei Bramlette and Riedel, 1954

Discoaster diatypus Bramlette and Sullivan, 1961

Discoaster distinctus Martini, 1958

Discoaster elegans Bramlette and Sullivan, 1961

Discoaster exilis Martini and Bramlette, 1963

Discoaster gemmeus Stradner, 1959

Discoaster icarus Stradner, 1973

Discoaster kugleri Martini and Bramlette, 1963

Discoaster lenticularis Bramlette and Sullivan, 1961

Discoaster lodoensis Bramlette and Riedel, 1954

Discoaster martinii Stradner, 1959

Discoaster mediosus Bramlette and Sullivan, 1961

Discoaster multiradiatus Bramlette and Riedel, 1954

Discoaster nobilis Martini, 1961

Discoaster nonaradiatus Klumpp, 1953

Discoaster pentaradiatus Tan Sin Hok, 1927

Discoaster quinqueramus Gartner, 1969

Discoaster saipanensis, Bramlette and Riedel, 1954

Discoaster septemradiatus (Klumpp) Martini, 1958

Discoaster sublodoensis Bramlette and Sullivan, 1961

Discoaster surculus Martini and Bramlette, 1963

Discoaster tamalis Kamptner, 1967

Discoaster tani nodifer Bramlette and Riedel, 1954

Discoaster variabilis Martini and Bramlette, 1963

Discoaster wemmelensis Achutus and Stradner, 1969

Discoasteroides kuepperi (Stradner) Bramlette and Sullivan, 1961

Discolithina desueta Müller, 1970

Discolithina distincta (Bramlette and Sullivan) Levin and Joerger, 1967

Discolithina exilis (Bramlette and Sullivan) Bukry and Kennedy, 1969

Discolithina japonica Takayama, 1967

Discolithina multipora (Kamptner) Martini, 1965

Discolithina ocellata (Bramlette and Sullivan) Perch-Nielsen, 1971

Discolithina plana (Bramlette and Sullivan) Perch-Nielsen, 1971

Emiliania huxleyi (Lohmann) Hay and Mohler, 1967

Ericsonia cava (Hay and Mohler) Perch-Nielsen, 1969

Ericsonia fenestrata (Deflandre and Fert) Stradner, 1968

Ericsonia subpertusa Hay and Mohler, 1967

Ellipsolithus distichus (Bramlette and Sullivan) Hay and Mohler, 1967

Ellipsolithus macellus (Bramlette and Sullivan) Sullivan, 1964

Fasciculithus billii Perch-Nielsen, 1971

Fasciculithus tympaniformis Hay and Mohler, 1967

Gephyrocapsa oceanica Kamptner, 1943

Gephyrocapsa sp.

Goniolithus fluckigeri Deflandre, 1957

Helicosphaera ampliaperta Bramlette and Wilcoxon, 1967

Helicosphaera carteri (Wallich) Kamptner, 1954

Helicosphaera compacta Bramlette and Wilcoxon, 1967 
Helicosphaera dinesenii (Perch-Nielsen) Jafar and Martini, 1975 Helicosphaera euphratis (Haq) Jafar and Martini, 1975 Helicosphaera heezeni (Bukry) Jafar and Martini, 1975 Helicosphaera lophota (Bramlette and Sullivan) Jafar and Martini, 1975 Helicosphaera perch-nielsenasae (Haq) Jafar and Martini, 1975 Helicosphaera recta (Haq) Jafar and Martini, 1975 Helicosphaera reticulata Bramlette and Wilcoxon, 1967 Helicosphaera sellii (Bukry and Bramlette) Jafar and Martini, 1975 Helicosphaera seminulum (Bramlette and Sullivan) Jafar and Martini, 1975 Heliolithus riedeli Bramlette and Sullivan, 1961

Hornibrookina australis Edwards and Perch-Nielsen, 1975

Imperiaster obscurus (Martini) Martini, 1970

Isthmolithus recurvus Deflandre, 1954

Koczyia fimbriata (Bramlette and Sullivan) Perch-Nielsen, 1971

Lanternithus minutus Stradner, 1962

Lithostromation perdurum Deflandre, 1942

Lophodolithus nascens Bramlette and Sullivan, 1961

Markalius inversus (Deflandre) Bramlette and Martini, 1964

Marthasterites bramlettei Brönnimann and Stradner, 1960

Marthasterites tribrachiatus (Bramlette and Riedel) Deflandre, 1959

Micrantholithus basquensis Martini, 1959

Micrantholithus mirabilis Locker, 1965

Micrantholithus pinguis Bramlette and Sullivan, 1961

Micrantholithus procerus Bukry and Bramlette, 1969

Micrantholithus vesper Deflandre, 1954

Naninfula deflandrei Perch-Nielsen, 1968

Nannotetraster pappi (Stradner) Perch-Nielsen, 1972

Neochiastozygus concinnus (Martini) Perch-Nielsen, 1971

Neochiastozygus junctus (Bramlette and Sullivan) Perch-Nielsen, 1971

Neococcolithes protenus (Bramlette and Sullivan) Hay and Mohler, 1967

Oolithotus fragilis (Lohmann) Martini and Müller, 1972

Pemma rotundum Klumpp, 1953

Pontosphaera pacifica Burns, 1973

Pontosphaera syracusana Lohmann, 1902

Pseudoemiliania lacunosa (Kamptner) Gartner, 1969

Reticulofenestra clatrata Müller, 1970

Reticulofenestra insignita Roth and Hay, 1967

Reticulofenestra lockeri Müller, 1970

Reticulofenestra pseudoumbilica (Gartner) Gartner, 1969

Reticulofenestra umbilica (Levin) Martini and Ritzkowski, 1968

Rhabdolithus solus Perch-Nielsen, 1971

Rhabdosphaera clavigera Murray and Blackman, 1898

Rhabdosphaera gladius Locker, 1967

Rhabdosphaera inflata Bramlette and Sullivan, 1961

Rhabdosphaera scabrosa (Deflandre) Bramlette and Sullivan, 1961

Rhabdosphaera spinula Levin, 1965

Rhabdosphaera stylifera Lohmann, 1902

Rhabdosphaera tenuis Bramlette and Sullivan, 1961

Rhabdosphaera vitrea (Deflandre) Bramlette and Sullivan, 1961

Rhomboaster cuspis Bramlette and Sullivan, 1961

Scapholithus fossilis Deflandre, 1954

Scyphosphaera apsteini Lohmann, 1902

Scyphosphaera conica Kamptner, 1955

Scyphosphaera intermedia Deflandre, 1942

Scyphosphaera pulcherima Deflandre, 1942

Scyphosphaera recurvata Deflandre, 1942

Sphenolithus abies Deflandre, 1954

Sphenolithus anarrhopus Bukry and Bramlette, 1969

Sphenolithus belemnos Bramlette and Wilcoxon, 1967

Sphenolithus furcatolithoides Locker, 1967

Sphenolithus heteromorphus Deflandre, 1953

Sphenolithus moriformis (Brönnimann and Stradner) Bramlette and Wilcoxon, 1967

Sphenolithus obtusus Bukry, 1971

Sphenolithus orphanknolli Perch-Nielsen, 1971

Sphenolithus predistentus Bramlette and Wilcoxon, 1967

Sphenolithus pseudoradians Bramlette and Wilcoxon, 1967

Sphenolithus spiniger Bukry, 1971

Sphenolithus radians Deflandre, 1954

Syracosphaera pulchra Lohmann, 1902
Thoracosphaera deflandrei Kamptner, 1956

Toweius callosus Perch-Nielsen, 1971

Toweius craticulus Hay and Mohler, 1967

Toweius eminens (Bramlette and Sullivan) Perch-Nielsen, 1971

Transversopontis pulcher (Deflandre) Hay, Mohler, and Wade, 1966

Transversopontis pulcheroides (Sullivan) Perch-Nielsen, 1971

Triquetrorhabdulus carinatus Martini, 1965

Triquetrorhabdulus rugosus Bramlette and Wilcoxon, 1967

Umbilicosphaera mirabilis Lohmann, 1902

Zygodiscus plectopons Bramlette and Sullivan, 1961

Zygodiscus sigmoides Bramlette and Sullivan, 1961

Zygolithus dubius Deflandre, 1954

Zygrhablithus bijugatus (Deflandre) Deflandre, 1959

\section{Cretaceous:}

Arkhangelskiella cymbiformis Vekshina, 1959

Braarudosphaera bigelowi (Gran and Braarud) Deflandre, 1947

Broinsonia parca (Stradner) Bukry, 1969

Chiastozygus litterarius (Gorka) Manivit, 1971

Corollithion achylosum (Stover) Thierstein, 1971

Corollithion signum Stradner, 1963

Cretarhabdus conicus Bramlette and Martini, 1964

Cretarhabdus coronadventis Reinhardt, 1966

Cretarhabdus crenulatus Bramlette and Martini, 1964

Cretarhabdus loriei Gartner, 1968

Cretarhabdus unicornis Stover, 1966

Cretaturbella mexicana Trejo, 1969

Cribrosphaerella ehrenbergi Archangelsky, 1912

Cylindralithus serratus Bramlette and Sullivan, 1964

Diazomatolithus lehmani Noël, 1965

Eiffellithus turriseiffeli (Deflandre) Reinhardt, 1965

Hayesites albiensis Manivit, 1971

Kamptnerius magnificus Deflandre, 1959

Lithastrimus floralis Stradner, 1962

Lithraphidites carniolensis Deflandre, 1963

Lithraphidites quadratus Bramlette and Martini, 1964

Lucianorhabdus cayeuxii Deflandre, 1959

Manivitella pemmatoides (Deflandre) Thierstein, 1971

Markalius circumradiatus (Stover) Perch-Nielsen, 1968

Micrantholithus hoschulzi (Reinhardt) Thierstein, 1971

Microrhabdulus decoratus Deflandre, 1959

Micula staurophora (Gardet) Stradner, 1963

Nannoconus bucheri Brönnimann, 1955

Nannoconus elongatus Brönnimann, 1955

Nannoconus globulus Brönnimann, 1955

Nannoconus kamptneri Brönnimann, 1955

Nannoconus minutus Brönnimann, 1955

Nannoconus truitti Brönnimann, 1955

Nannoconus wassalli Brönnimann, 1955

Nephrolithus frequens Gorka, 1957

Parhabdolithus angustus (Stradner) Stradner, Adamiker, and Maresch, 1968

Parhabdolithus asper (Stradner) Manivit, 1971

Parhabdolithus embergeri (Noël) Stradner, 1963

Parhabdolithus infinitus (Worsley) Thierstein, 1972

Parhabdolithus splendens (Deflandre) Noël, 1969

Prediscosphaera cretacea (Archangelsky) Gartner, 1968

Reinhardites anthophorus (Deflandre) Perch-Nielsen, 1968

Scapholithus fossilis Deflandre and Fert, 1954

Stephanolithion laffittei Noël, 1956

Tetralithus aculeus (Stradner) Gartner, 1968

Tetralithus gothicus Deflandre, 1959

Tetralithus obscurus Deflandre, 1959

Tetralithus pyramidus Gardet, 1955

Tetralithus trifidus (Stradner) Bukry, 1973

Watznaueria barnesae (Black) Perch-Nielsen, 1968

Watznaueria biporta Bukry, 1969

Watznaueria britannica (Stradner) Reinhardt, 1964

Watznaueria communis Reinhardt, 1966

Zygodiscus diplogrammus (Deflandre and Fert) Gartner, 1968

Zygodiscus sigmoides Bramlette and Sullivan, 1961 


\section{ACKNOWLEDGMENTS}

The investigation was supported by the Deutsche Forschungsgemeinschaft. SEM-pictures were taken with a Stereoscan Mar 2, which was provided to the GeologischPaläontologisches Institut der Universität Frankfurt am Main by the VW-stiftung.

My thanks are also given to Prof. Dr. E. Martini (Frankfurt am Main) for valuable discussions and for reviewing this paper as well as to Dr. D. Bukry (La Jolla, California).

\section{REFERENCES}

Benedek, P.N.v. and Müller, C., 1976. Die Grenze Unter-/Mittel-Oligozän am Doberg bei Bünde/Westfalen. I. Phyto- and Nannoplankton, N. Jb. Geol. Paläont., Mh., v. 3, p. 129-144.

Berggren, W.A., 1972. Late Pliocene-Pleistocene glaciation. In Laughton, A.S., Berggren, W.A., et al., Initial Reports of the Deep Sea Drilling Project, v. 12: Washington (U.S. Government Printing Office), p. 953-963.

Berggren, W.A., Phillips, J.D., Bertels, A., and Wall, D., 1967. Late Pliocene-Pleistocene stratigraphy in deep-sea cores from the south-central Atlantic, Nature, v. 216, p. 253.

Bettenstaedt, F., Fahrion, H., Hiltermann, H., and Wick, W., 1962.Tertiär Norddeutschlands. Stratigraphie and Fazies. In Leitfossilien der Mikropaläontologie, Berlin.

Bizon, G., and Müller, C., 1977. Remarks on some biostratigraphic problems in the Mediterranean Neogene, Int. Symp. on the Structural History of the Mediterranean Basins: Paris (Technip), p. 381-390.

1978. Remarks on the determination of the Plio/Pleistocene boundary in the Mediterranean. In Hsü, K.J., Montadert, L., et al., Initial Reports of the Deep Sea Drilling Project, v. 42, Part 1: Washington (U.S. Government Printing Office). p. 847-854.

Blow, W.H., 1969. Late middle Eocene to Recent planktonic foraminiferal biostratigraphy. In Brönnimann, P., and Renz, H.H. (Eds.), Internat. Conf. Plankt. Microfossils, Ist Proc.: Leiden (E.J. Brill), p. 199-241.

Bouché, P.M., 1962. Nannofossils calcaires du Lutetian du Bassin de Paris, Rev. Micropaleont. v. 5, p. 75-103. , 1965. Etat des connaissances sur les nannofossiles calcaires du Crétacé inférieur: Coll. Crétacé inférieur Dijon-Lyon 1963, Mem. B.R.G.M., no. 34, p. 451-459.

Bramlette, M.N. and Sullivan, F.R., 1961. Coccolithophorids and related nannoplankton of the early Tertiary in California, Micropaleontology, v. 7, p. 129-188.

Bukry, D., 1971. Cenozoic calcareous nannofossils from the Pacific Ocean, San Diego Soc. Nat. Hist. Trans., v. 16, p. 303-327.

- 1972. Further comments on coccolith stratigraphy, Leg 12, Deep Sea Drilling Project. In Laughton, A.S., Berggren, W.A., et al., Initial Reports of the Deep Sea Drilling Project, v. 12: Washington (U.S. Government Printing Office), p. 1071-1083.

1973. Coccolith and silicoflagellate stratigraphy, Tasman Sea and southwestern Pacific Ocean, Deep Sea Drilling Project Leg 21. In Burns, R.E., Andrews, J.E., et al., Initial Reports of the Deep Sea Drilling Project, v. 21: Washington (U.S. Government Printing Office), p. 885-893.

Bukry, D. and Bramlette, M.N., 1969. Some new and stratigraphically useful calcareous nannofossils of the Cenozoic, Tulane Studies Geol. Paleontol., v. 7, p. 131-142. 1970. Coccoliths age determinations Leg 3, Deep Sea Drilling Project. In Maxwell, A.E., von Herzen, R., et al., Initial Reports of the Deep Sea Drilling Project, v. 3: Washington (U.S. Government Printing Office), p. 589-611.
Čepek, P. and Hay, W. W., 1969. Calcareous nannoplankton and biostratigraphic subdivision of the Upper Cretaceous, Gulf Coast Assoc. Geol. Soc. Trans., v. 19, p. 323-336.

Edwards, A. R., 1971. A calcareous nanno-plankton zonation of the New Zealand Paleogene, 2nd. Plankt. Conf. Proc., Rome 1970 , v. I, p. $381-420$.

, 1973. Calcareous nannofossils from the southwest Pacific, Deep Sea Drilling Project Leg 21. In Burns, R. E., Andrews, J. E., et al., Initial Reports of the Deep Sea Drilling Project, v. 21: Washington (U.S. Government Printing Office), p. 641-691

Edwards, A.R., and Perch-Nielsen, K., 1975. Calcareous nannofossils from the southern Southwest Pacific, Deep Sea Drilling Project, Leg 29. In Kennett, J.P., Houtz, R.E., et al., Initial Reports of the Deep Sea Drilling Project, v. 29: Washington (U.S. Government Printing Office), p. 469-539.

Gartner, S., Jr., 1971. Calcareous nannofossils from the JOIDES Blake Plateau cores and revision of Paleogene nannofossil zonation: Tulane Stud. Geol. Paleontol., v. 8, p. 101-121. 1973. Absolute chronology of the late Neogene calcareous nannofossil succession in the Equatorial Pacific, Geol. Soc. Am. Bull., v. 84, p. 2021-2034.

Hay, W. W. and Mohler, H., 1967. Calcareous nannoplankton from early Tertiary rocks at Pont Labau, France, and Paleocene-early Eocene correlations, J. Paleontol., v. 41, p. $1505-1541$.

Hays, J. D., Saito, T., Opdyke, N. D., and Burckle, L. H., 1969. Pliocene-Pleistocene sediments of the equatorial Pacific: their paleomagnetic, biostratigraphy, and climatic record, Geol. Soc. Am. Bull., v. 80, p. 1481-1514.

Locker, S., 1972. Coccolitheneen aus dem Paläogen Mitteleuropas, Paläont. Abh., Abt. B., Paläobot., v. 3, p. $735-853$.

Manivit, H., 1971. Les nannofossiles calcaires du Crétacé français (de l'Aptien au Danien). Essai de biozonation appuyée sur les stratotypes, Thèse, Université de Paris, p. 1-187.

Martini, E., 1958. Discoasteriden und verwandte Formen in NW-deutschen Eozän (Coccolithophorida). 2. Stratigraphische Auswertung, Senckenb. Lethaea, v. 40, p. 137-157.

- 1971. Standard Tertiary and Quaternary calcareous nannoplankton zonation, 2nd. Plankt. Conf. Proc., Rome 1970 , v. 2, p. $739-785$.

, 1976. Cretaceous to Recent calcareous nannoplankton from the Central Pacific Ocean (DSDP Leg 33). In Schlanger, S. O., Jackson, E. D., et al., Initial Reports of the Deep Sea Drilling Project, v. 33: Washington (U.S. Government Printing Office), p. 383-423.

Martini, E., and Müller, C., 1973. Nannoplankton-Gemeinschaften im Miozän and Pliozän des Nordseebeckens, N. Jb. Geol. Paläontol., p. 555-564.

McIntyre, A., and Bé, A. W. H., 1967. Modern Coccolithophoridae of the Atlantic Ocean-I. Placoliths and cyrtoliths, Deep-Sea Res., v. 14, p. 561-597.

Moorkens, T. L., 1975. Palökologische Bedeutung einiger Vergesellschaftungen von sandschaligen Foraminiferen aus dem NW europäischen Alttertiär und ihre Beziehung zu Muttergesteinen: DGMK-Fachgruppentagung 1975 Hannover, Compendium 75/76, Ergänzungsdb. Z. Erdöl und Kohle, Erdgas, Petrochemie, p. 77-95.

Müller, C., 1970. Nannoplankton aus dem Mittel-Oligozän von Norddeutschland und Belgien, N. Jb. Geol. Paläont., Abh., v. 135 , p. $82-101$.

, 1971. Nannoplankton-Gemeinschaften aus dem Wdeutschen Mittel-Oligozän, Notizbl. hess. L.-Amt Bodenforsch., v. 99, p. 43-53.

, 1974a. Calcareous nannoplankton, Leg 25 (western Indian Ocean). In Simpson, E. S. W., Schlich, R., et al., 
Initial Reports of the Deep Sea Drilling Project, v. 25: Washington (U.S. Government Printing Office), p. 579-633.

, 1974b. Nannoplankton aus dem Mittel-Miozän von Walbersdorf (Burgenland), Senckenb. Lethaea, v. 55, p. 389-405.

, 1976. Tertiary and Quaternary calcareous nannoplankton in the Norwegian-Greenland Sea, DSDP Leg 38, In Talwani, M., Udintsev, G., et al., Initial Reports of the Deep Sea Drilling Project, v. 38: Washington (U.S. Government Printing Office), p. 823-841. , 1978. Neogene calcareous nannofossils from the Mediterranean-Leg 42A of the Deep Sea Drilling Project. In Hsü, K. J., Montadert, L., et al., Initial Reports of the Deep Sea Drilling Project, v. 42, Part 1: Washington (U.S. Government Printing Office), p. 727-752.

Noël, D., 1968. Nature et genèse des alternances de marnes et de calcaires de Barrémien d'Angles (Fosse vocontienne, Basses Alpes), C.R. Acad. Sci. Paris, v. 266, p. 1223-1225.

Norris, G. and Dörhöfer, G., 1977. Upper Mesozoic dinoflagellate biostratigraphy, North Am. Paleontol. Conv. II, Kansas 1977 (abstract), J. Paleontol., v. 51, p. 19.

Perch-Nielsen, K., 1967. Nannofossilien aus dem Eozän von Dänemark, Eclog. Geol. Helv., v. 60, p. 19-32.

, 1968. Beobachtungen im Elektronenmikroskop an Micrantholithus mirabilis und Marthasterites obscurus (Nannoplankton), Medd. Dansk Geol. Foren. Kobenhavn, v. 18 , p. $251-254$.

, 1971. Elektronenmikroskopische Untersuchungen an Coccolithen und verwandten Formen aus dem Eozän von Dänemark, K. Danske Videnskabernes Selskab, Biol. Skrifter, v. 18 , p. $1-76$.

, 1972. Remarks on Late Cretaceous to Pleistocene coccoliths from the North Atlantic. In Laughton, A. S., Berggren, W. A., et al., Initial Reports of the Deep Sea Drilling Project, v. 12: Washington (U.S. Government Printing Office), p. 1003-1069.

Proto Decima, F., Roth, P. H., and Todesco, L., 1975. Nannoplancton calcareo del Paleocene e del Eocene della Sezione di Possagno, Schweiz. Paläont. Abh., v. 97, p. 35-161.
Rögl, F. and Müller, C., 1976. Das Mittelmiozän und die Baden-Sarmat Grenze in Walbersdorf (Burgenland), Ann. Naturhistor. Mus. Wien, v. 80, p. 221-232.

Roth, P. H., 1973. Calcareous nannofossils-Leg 17, Deep Sea Drilling Project. In Winterer, E. L., Ewing, J. E., et al., Initial Reports of the Deep Sea Drilling Project, v. 17: Washington (U.S. Government Printing Office), p. 695-795.

-1977 . Cretaceous calcareous nannoplankton, diversity and paleoceanography.

Ryan, W. B. F., Cita, M. B., Dreyfus Rawson, M., Burckle, L. H., and Saito, T., 1974. A paleomagnetic assignment of Neogene stage boundaries and the development of isochronous datum planes between the Mediterranean, the Pacific and Indian Oceans in order to investigate the response of the world ocean to the Mediterranean "Salinity Crisis," Riv. Ital. Paleontol., v. 80, p. 631-688.

Sherwood, R. W., 1974. Calcareous nannofossil systematics, paleoecology, and biostratigraphy of the Middle Eocene Weches Formation of Texas, Tulane Studies Geol. Paleontol., v. 11, p. $1-79$.

Sullivan, F., 1965. Lower Tertiary nannoplankton from the California coast ranges. II Eocene, Univ. Calif. Publ. Geol. Sci., v. 53, p. 1-75. , 1973. Lower Cretaceous nannoplankton biostratigraphy, Abh. Geol. Bundesanst., Wien, v. 29. , 1976. Mesozoic calcareous nannoplankton biostratigraphy of marine sediments, Marine Micropaleontol. v. 1, p. 325-362.

Thierstein, H. R. and Haq, B. U., 1977. Maastrichtian/Danian biogeographic variations in calcareous nannoplankton, North Am. Paleontol. Conv. II, Kansas 1977 (abstract), J. Paleontol., v. 51 , p. 28-29.

van Hinte, J. E., 1976. A Cretaceous time scale, Am. Assoc. Petrol. Geol. Bull., v. 60, p. 498-516.

Wilcoxon, J. A., 1972. Upper Jurassic-Lower Cretaceous calcareous nannoplankton from the western North Atlantic. In Hollister, C. D., Ewing, J. I., et al., Initial Reports of the Deep Sea Drilling Project, v. 11: Washington (U.S. Government Printing Office), p. 427-458.

Worsley, T. R. and Martini, E., 1970. Late Maastrichtian nannoplankton provinces, Nature, v. 225, p. 1242-1243. 

PLATE 1

Figure 1 Markalius inversus (Deflandre) Bramlette and Martini, 1964.

$5000 \times$, distal view.

Sample 405-9-2, 114-115 cm.

Figure 2 Ellipsolithus distichus(Bramlette and Sullivan)Hay and Mohler, 1967.

$5000 \times$, distal view.

Sample 405-14-1, 124-125 cm.

Figure 3 Neococcolithes protenus (Bramlette and Sullivan) Hay and Mohler, 1967.

$4500 \times$. Sample 401-14-1, 26-27 cm.

Figure 4 Ericsoniacava (Hay and Mohler) Perch-Nielsen, 1969. $5000 \times$, distal view.

Sample 401-14-3, 64-65 cm.

Figures 5, 6 Discoaster mediosus Bramlette and Sullivan, 1961. Sample 401-14-3, 64-65 cm.

5. $2300 \times$.

6. $2800 \times$.

Figure $7 \quad$ Nannoconus truitti Brönnimann, 1955.

$3500 \times$.

Sample 402A-35-2, 25-26 cm

Figure 8

Nannoconus kamptneri Brönnimann, 1955.

$2500 \times$.

Sample $402 \mathrm{~A}-35-2,25-26 \mathrm{~cm}$.

Figure 9 Nannoconus wassilli Brönnimann, 1955.

$2500 \times$.

Sample 402A-35-2, 25-26 cm.

Figure $10 \quad$ Nannoconus sp.

$4250 \times$.

Sample 402A-35-2, 25-26 cm.

Figure 11, 12 Conosphaera mexicana Trejo, 1969.

$5000 \times$.

Sample 402A-35-2, 25-26 cm. 
PLATE 1

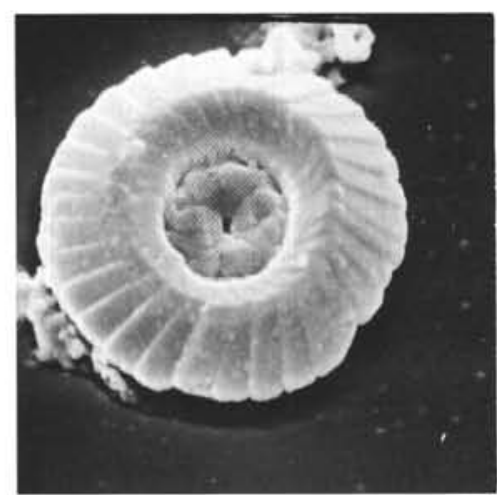

1

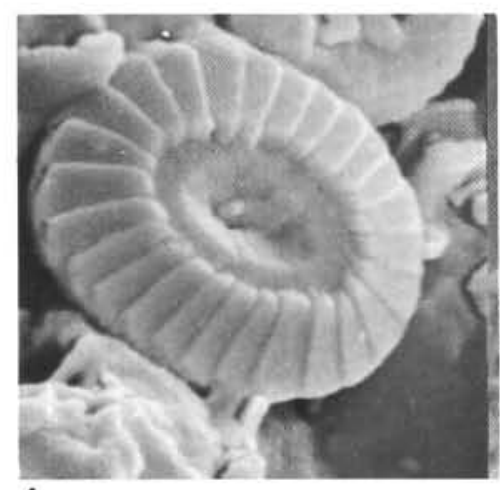

4

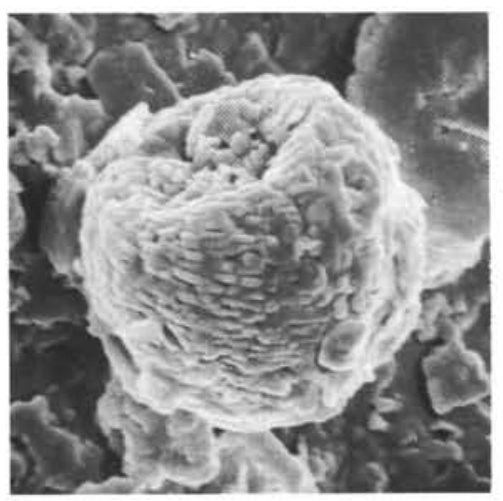

7

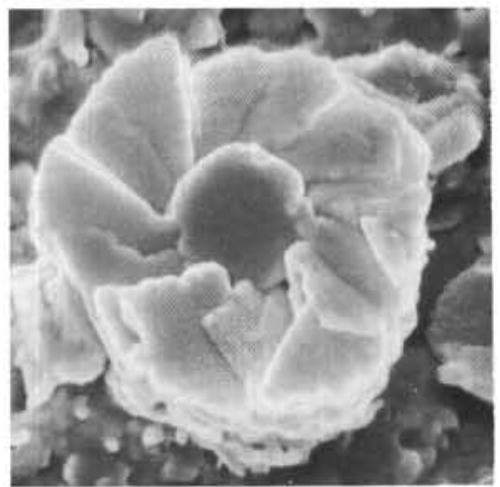

10
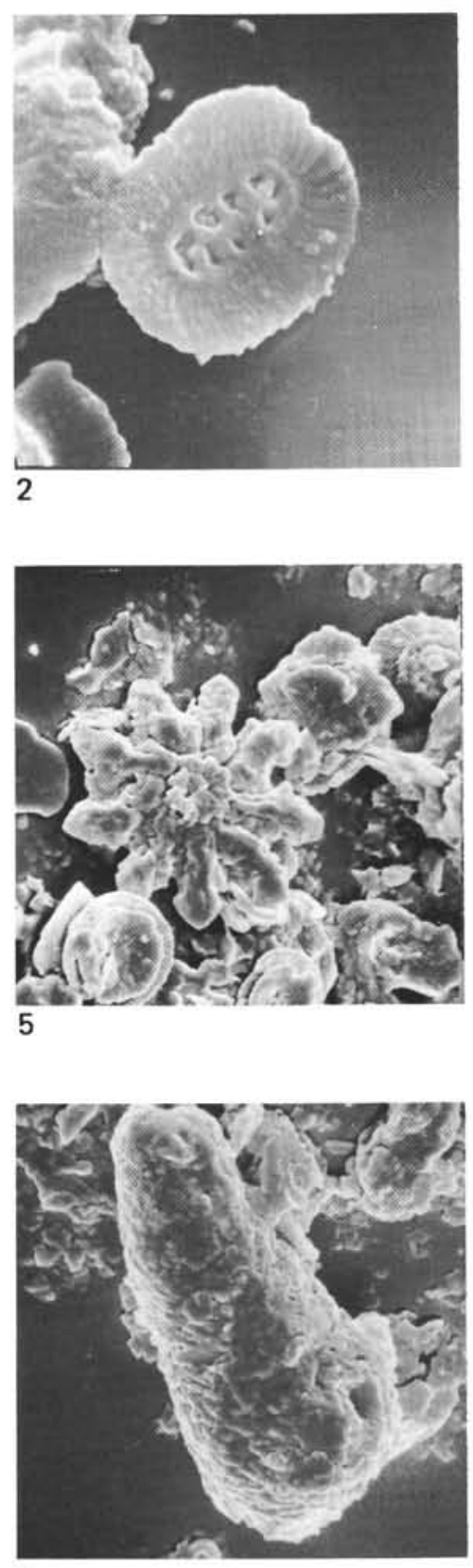

8

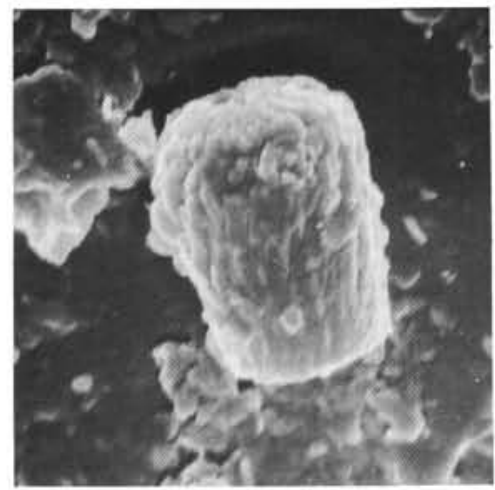

11
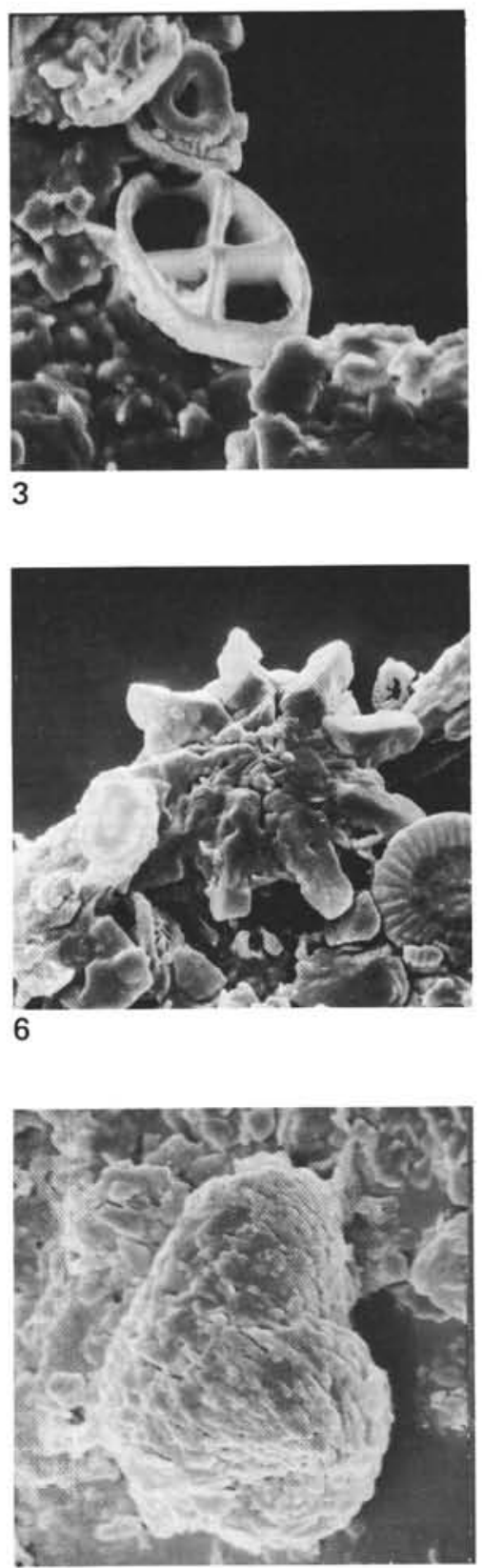

9

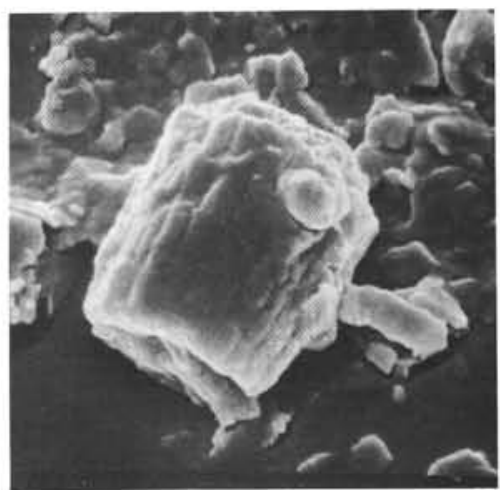

12 


\section{PLATE 2}

Figures 1, 2 Toweius eminens (Bramlette and Sullivan)

Perch-Nielsen, 1971.

Sample 401-14-3, 64-65 cm. Distal views.

1. $4500 \times$.

2. $5100 \times$.

Figure 3 Toweius craticulus Hay and Mohler, 1967.

$5700 \times$, distal view.

Sample 401-14-2, 111-112 cm.

Figure 4 Toweius callosus Perch-Nielsen, 1971.

$5000 \times$, distal view.

Sample 401-14-1, 26-27 cm.

Figures 5, 6 Hornibrookina australis Edwards and Perch-Nielsen, 1975.

$5000 \times$, distal views.

Sample 401-14-3, 64-66 cm.

Figures 7-9 Rhomboaster cuspis Bramlette and Sullivan, 1961.

$2600 \times$.

Sample 401-14-3, 64-65 cm.

Figure $10 \quad$ Zygolithus dubius Deflandre, 1954.

$5000 \times$.

Sample 405-14-1, 124-125 cm.

Figures 11, 12 Discoaster multiradiatus Bramlette and Riedel, 1954.

$2700 \times$.

Sample 401-14-3, 64-65 cm. 
PLATE 2

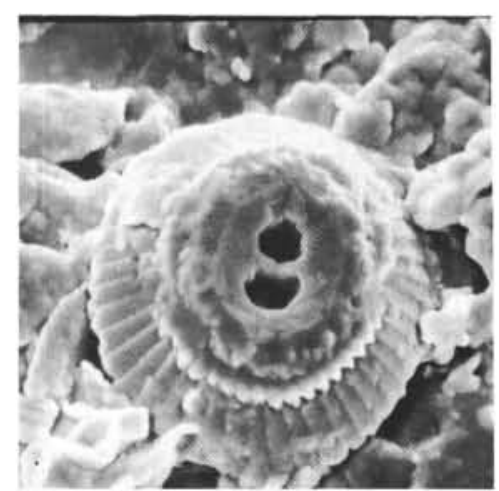

$$
1
$$
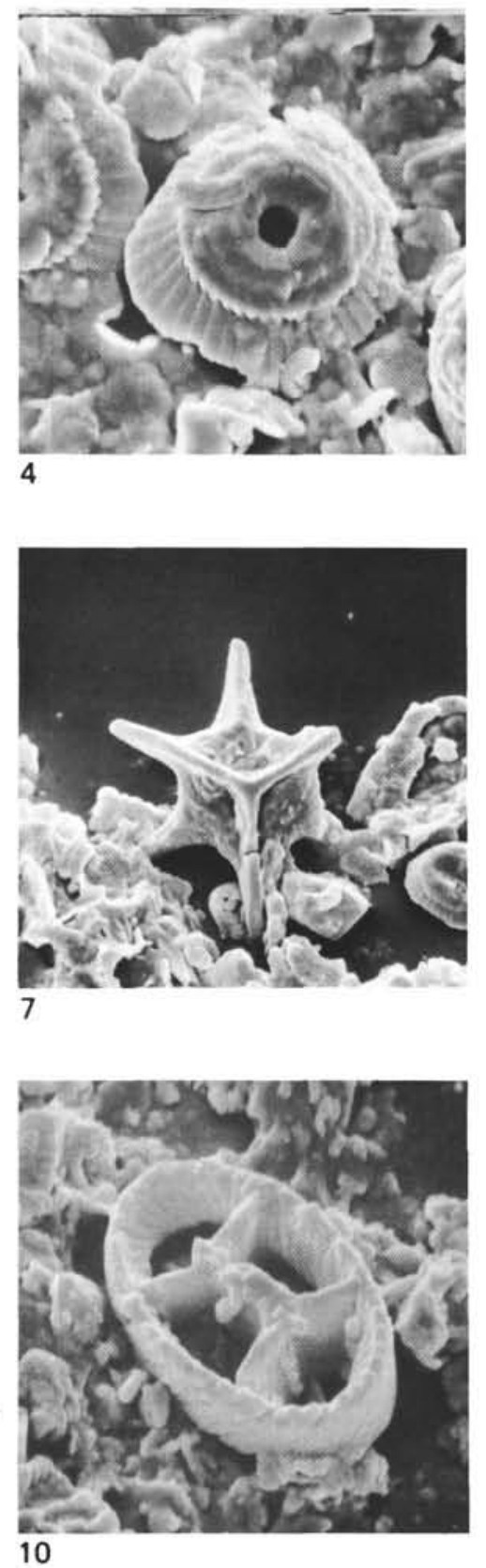
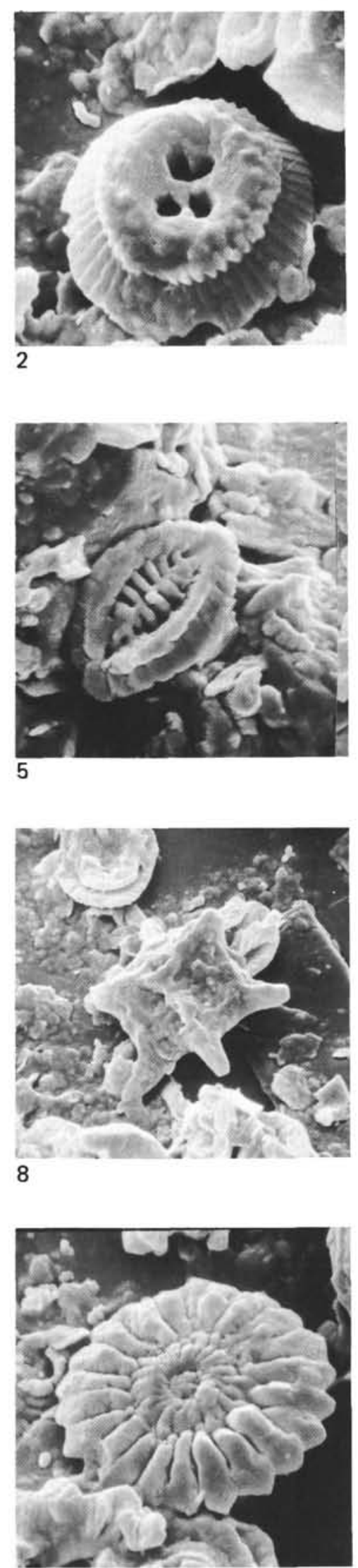

11

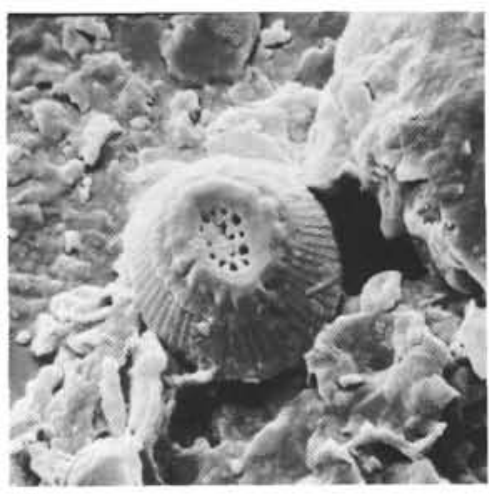

3
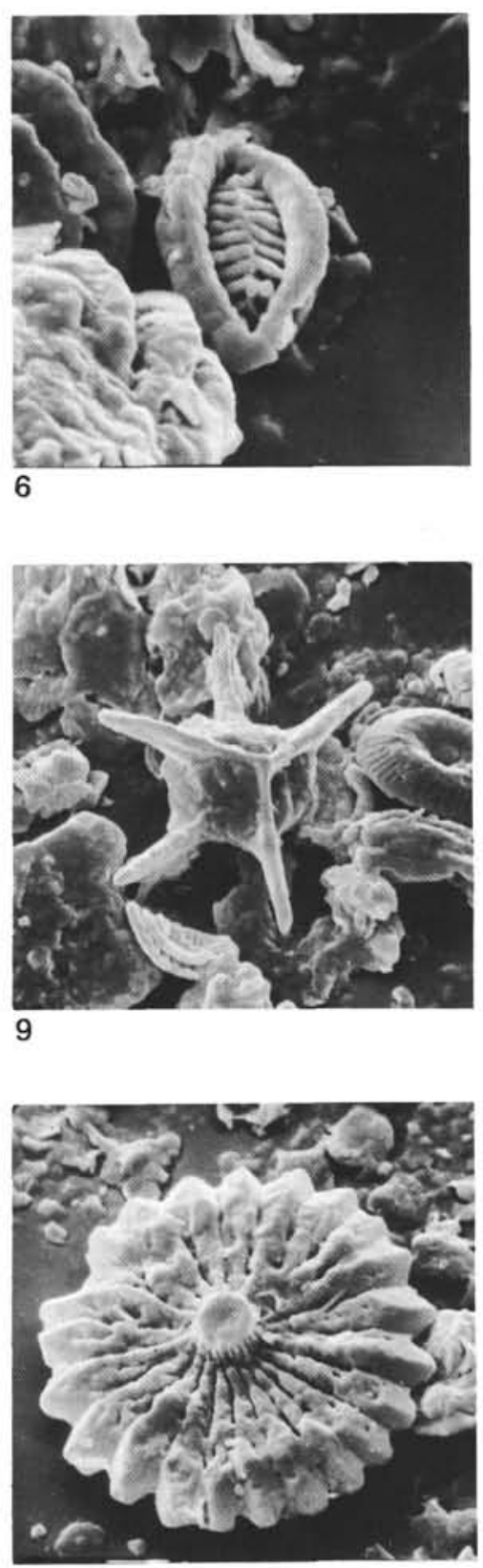

12 


\section{PLATE 3}

Figure 1

Figure 2

Figure 3

Figure 4

Figure 6

Figure 7

Figure 9

Figure 10
Sphenolithus sp.

$4500 \times$.

Sample 401-14-1, 26-27 cm.

Sphenolithus primus Perch-Nielsen, 1971.

$5000 \times$.

Sample 400A-57-2, 148-149 cm.

Sphenolithus furcatolithoides Locker, 1967.

$4000 \times$.

Sample 401-5-1, 105-106 cm.

Sphenolithus moriformis (Brönnimann and Stradner) Bramlette and Wilcoxon, 1967.

$5000 \times$.

Sample 402A-5-2, 9-10 cm.

Chiasmolithus grandis (Bramlette and Riedel) Radomski, 1968 and Chiasmolithus solitus (Bramlette and Sullivan) Locker, 1968.

$2000 \times$.

Sample 405-14-1, 124-125 cm.

Chiasmolithus grandis (Bramlette and Riedel) Radomski, 1968.

$2750 \times$, distal view.

Sample 405-9-2, 24-25 cm.

Chiasmolithus solitus (Bramlette and Sullivan) Locker, 1968.

$3000 \times$, distal view.

Sample 404-7-1, 13-14 cm.

Chiasmolithus titus Gartner, 1970.

$5000 \times$, distal view.

Sample 404-7-1, 13-14 cm.

Campylosphaera dela (Bramlette and Sullivan) Hay and Mohler, 1967.

$5250 \times$, distal view.

Sample 401-14-3, 131-132 cm.

Cruciplacolithus crux (Deflandre and Fert) Roth, 1970.

$4600 \times$, distal view.

Sample 401-10-4, 131-132 cm.

Figures 11, 12 Coccolithus staurion (Bramlette and Sullivan) Gartner, 1971.

$5000 \times$, distal views.

Sample 405-14-2, 36-37 cm. 
PLATE 3

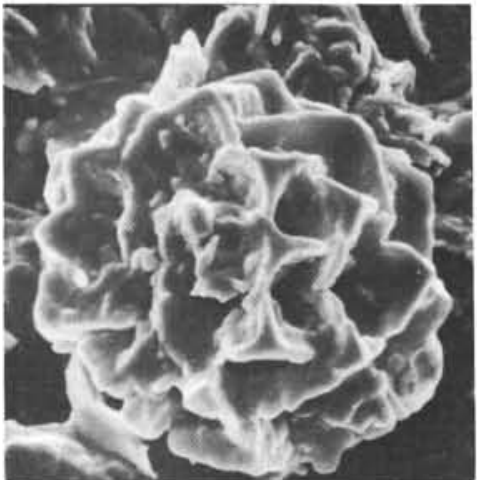

1
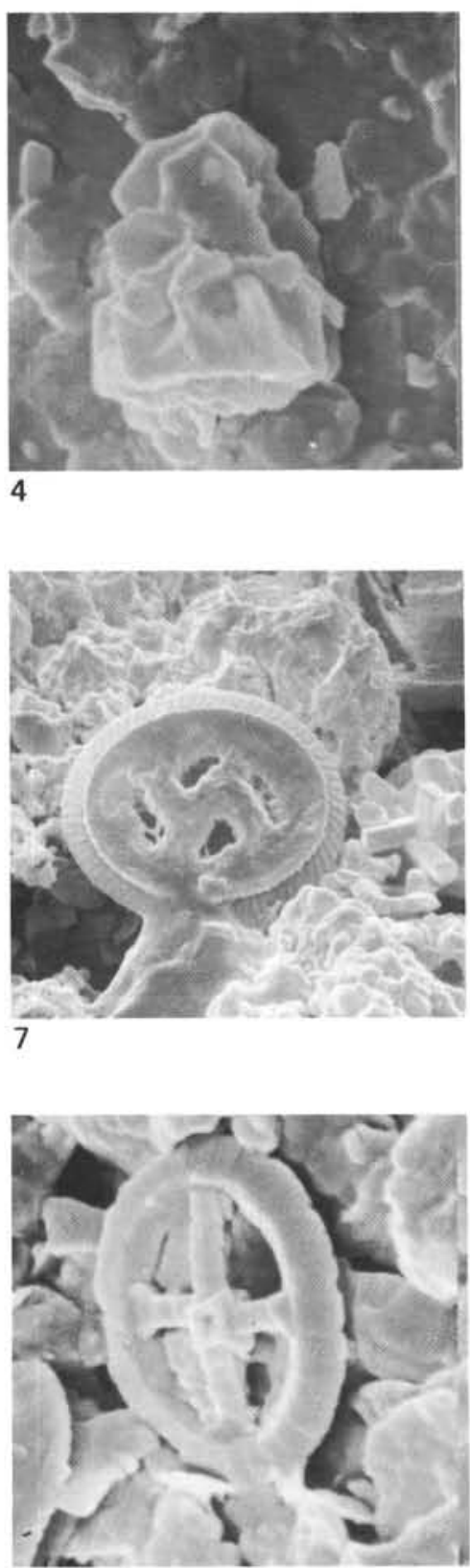

10
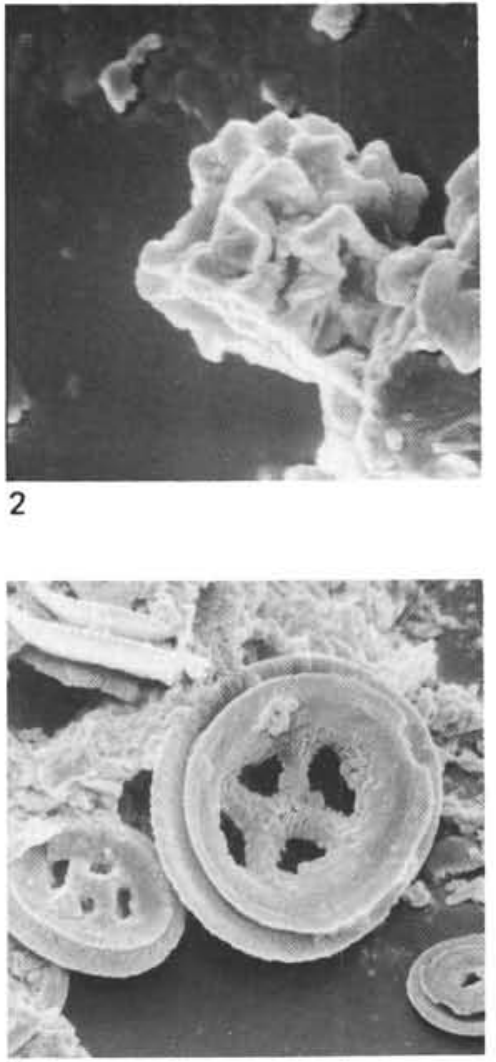

5
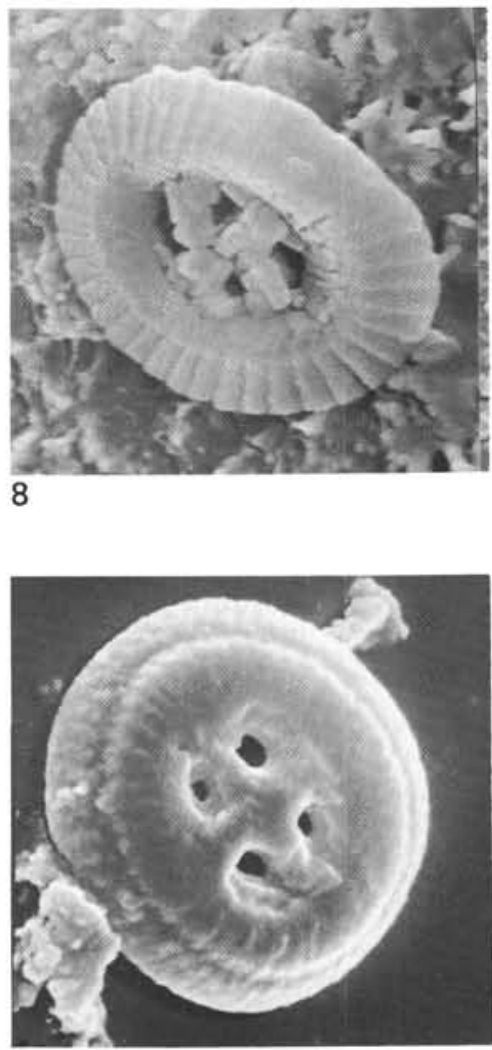

11

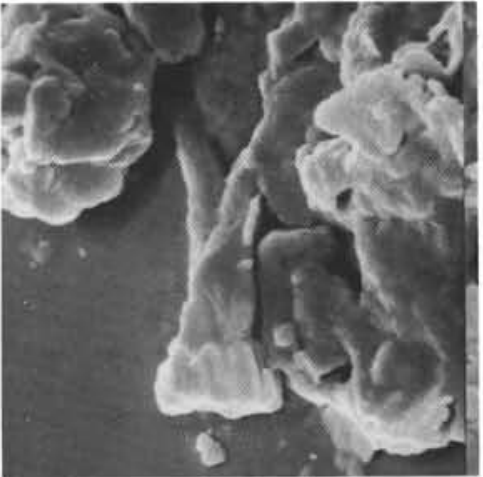

3

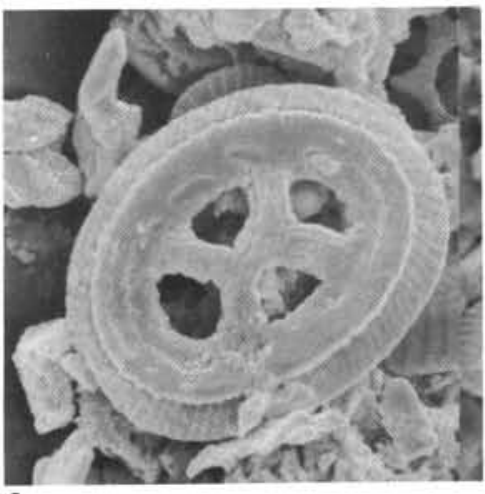

6
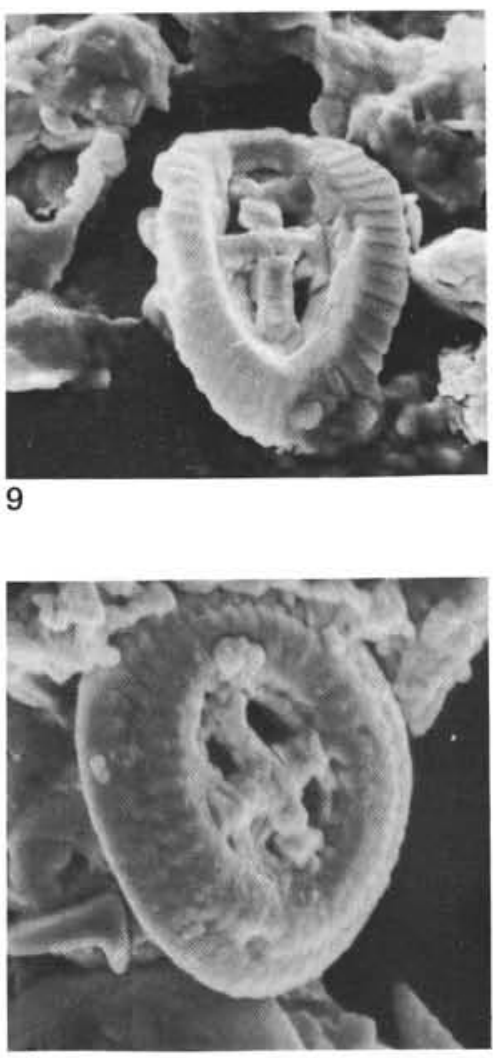


\section{PLATE 4}

Figures 1, 2 Discoaster barbadiensis Tan Sin Hok, 1927. $4600 \times$.

Sample 401-10-4, 131-132 cm.

Figures 3, 4, 6 Discoaster elegans Bramlette and Sullivan, 1961. Sample 405-14-1, 124-125 cm.

3. $4200 \times$.

4, 6. $3200 \times$.

Figure 5 Discoaster sp. $3700 \times$.

Sample 405-14-1, 124-125 cm.

Figures 7-9 Discoaster lodoensis Bramlette and Sullivan, 1961. Sample 405-14-1, 124-125 cm.

7. $1900 \times$.

$8,9.5000 \times$.

Figures 10, 11 Discoaster mirus Deflandre, 1954. Sample 405-14-1, $124-125 \mathrm{~cm}$.

10. $5000 \times($ ?Discoaster brönnimanni Stradner, 1961).

11. $4000 \times$.

Figure 12 Discoaster distinctus Martini, 1958. $5000 \times$.

Sample 405-14-1, 124-125 cm. 
PLATE 4

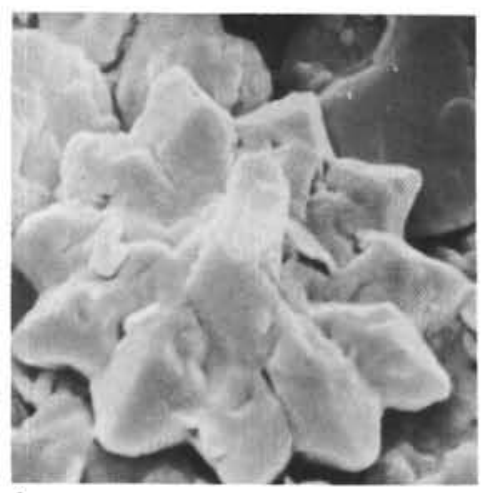

1
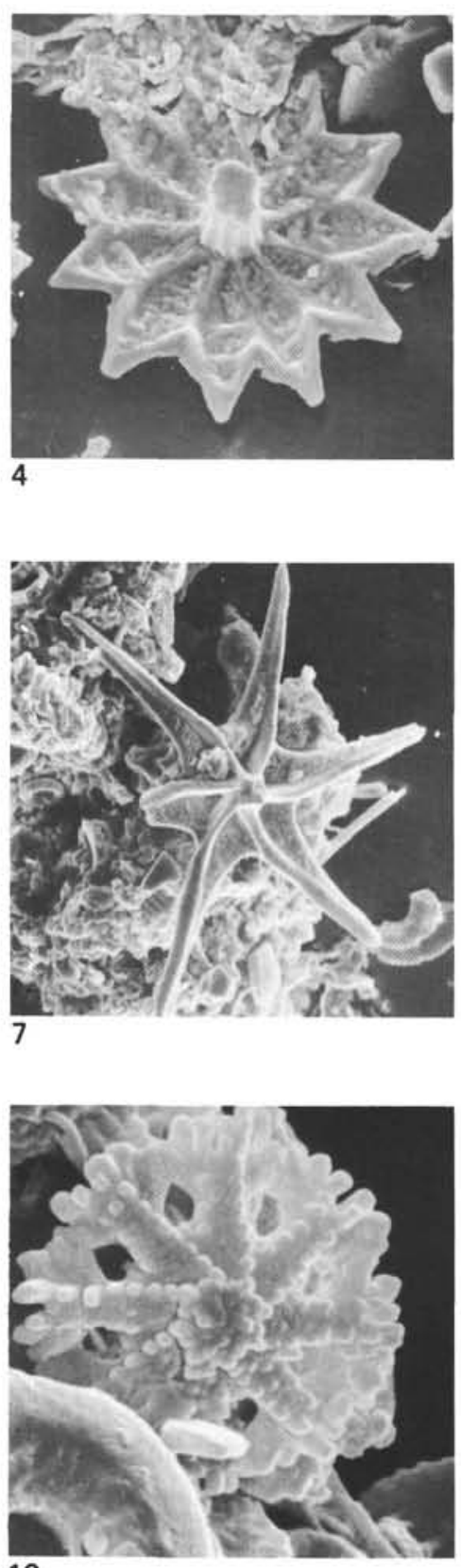
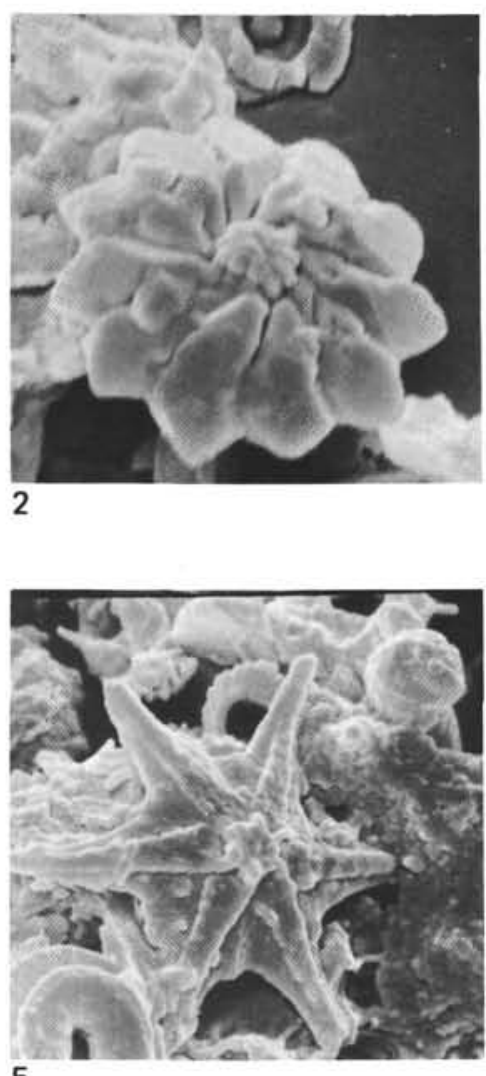

5

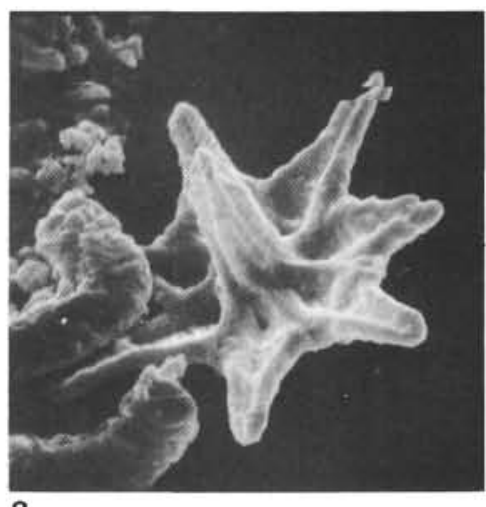

8

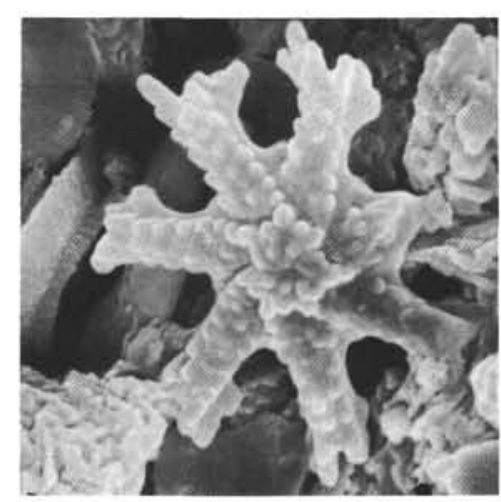

11

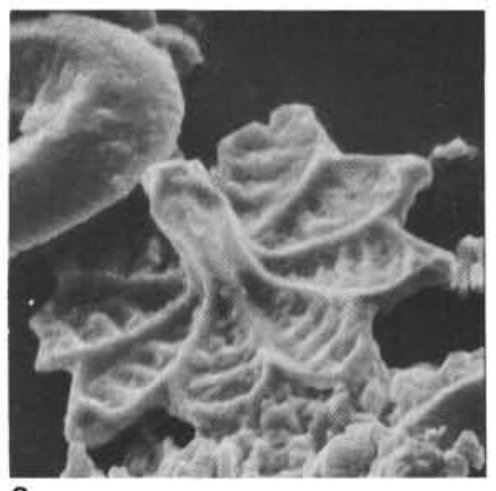

3
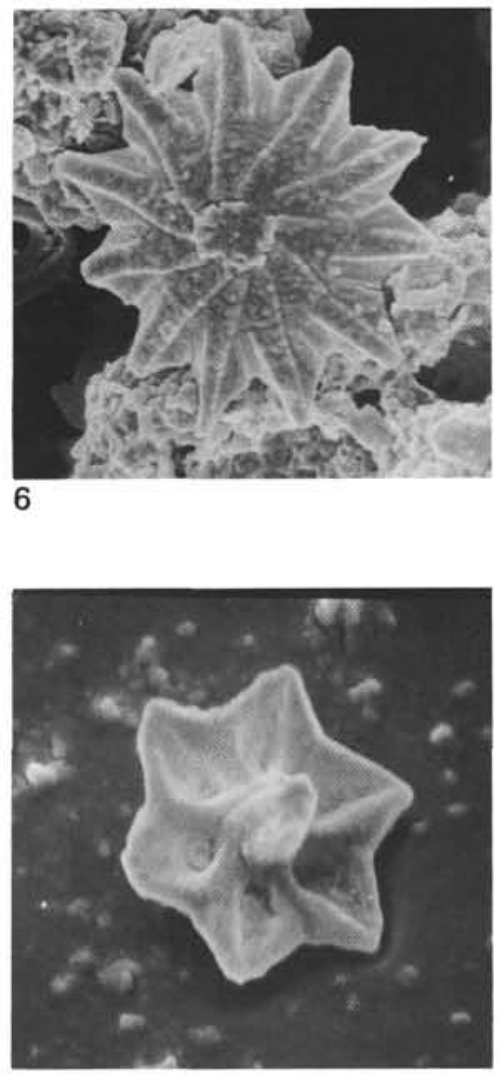

9

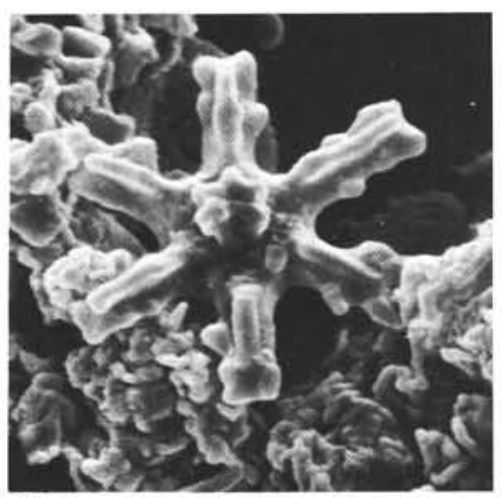

12 
Figure 1

Figure 2

Figure 3

Figure 4

Figure 5

Figure 8

Figure 10

Figure 11

Figure 12
Transversopontis pulcher (Deflandre) Hay, Mohler, and Wade, 1966.

$2500 \times$, distal and proximal view.

Sample 405-14-1, 124-125 cm.

Transversopontis pulcher (Deflandre) Hay, Mohler, and Wade, 1966.

$2500 \times$.

Sample 405-14-1, 124-125 cm.

Discolithina plana (Bramlette and Sullivan) Perch-Nielsen, 1971.

$4500 \times$, proximal view.

Sample 405-14-2, 36-37 cm.

Discolithina ocellata (Bramlette and Sullivan) Perch-Nielsen, 1971.

$3800 \times$, distal view.

Sample 405-25-1, 58-59 cm.

Koczyia fimbriata (Bramlette and Sullivan) Perch-Nielsen, 1971.

$2500 \times$, distal view.

Sample 402A-5-2, 9-10 cm.

Transversopontis panarium (Deflandre) Locker, 1968.

$5000 \times$, proximal view.

Sample 405-14-1, 124-125 cm.

Discolithina sp.

$5000 \times$, distal view.

Sample 403-36-3, 8-9 cm.

Discolithina punctosa (Bramlette and Sullivan) Perch-Nielsen, 1971.

$4500 \times$, distal view.

Sample 405-14-2, 36-37 cm.

Transversopontis $\mathrm{sp}$.

$4000 \times$, proximal view.

Sample 404-7-1, 13-14 cm.

Discolithina ocellata (Bramlette and Sullivan) Perch-Nielsen, 1971.

$4000 \times$, proximal view.

Sample 404-7-1, 13-14 cm.

Thoracosphaera prolata Bukry and Bramlette, 1969. $900 \times$.

Sample 401-14-1, 26-27 cm.

Thoracosphaera deflandrei Kamptner, 1956.

$1100 \times$.

Sample 401-14-3, 64-65 cm. 
PLATE 5
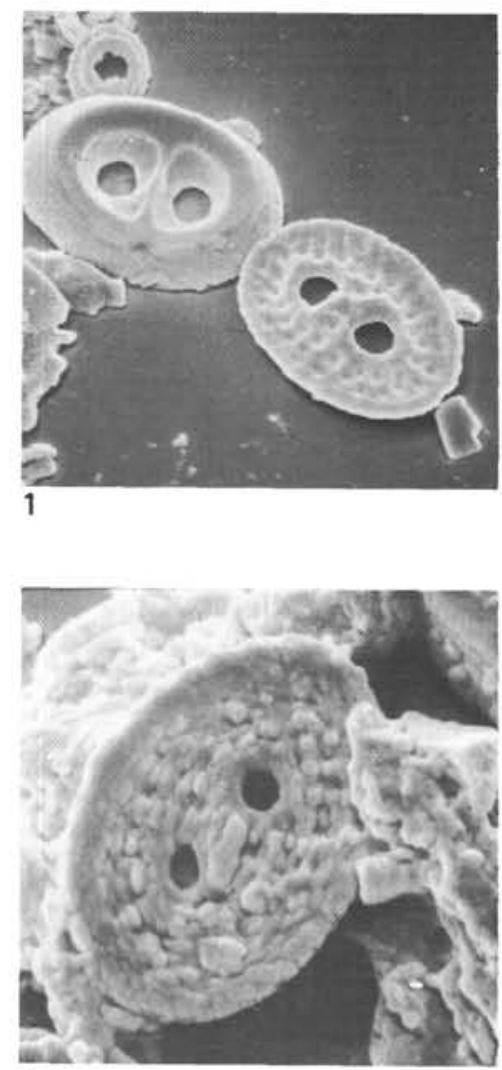

4

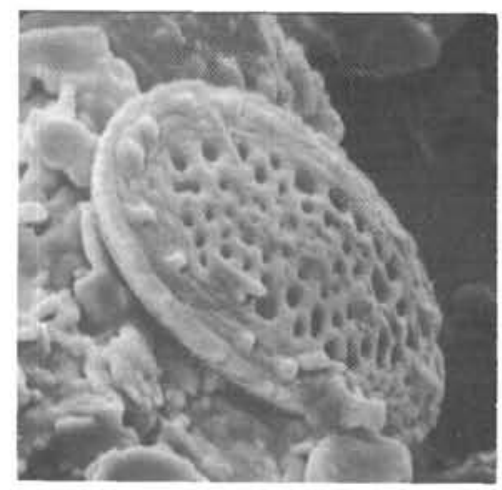

7

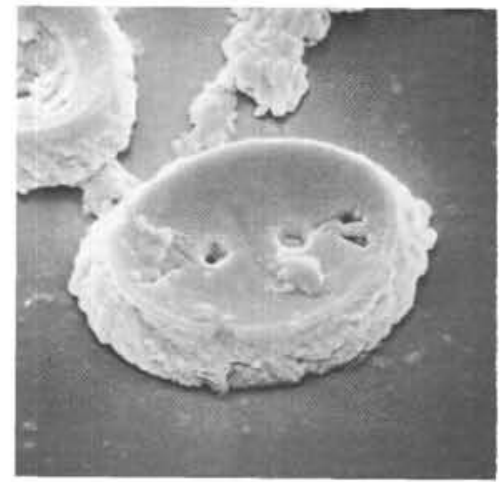

10
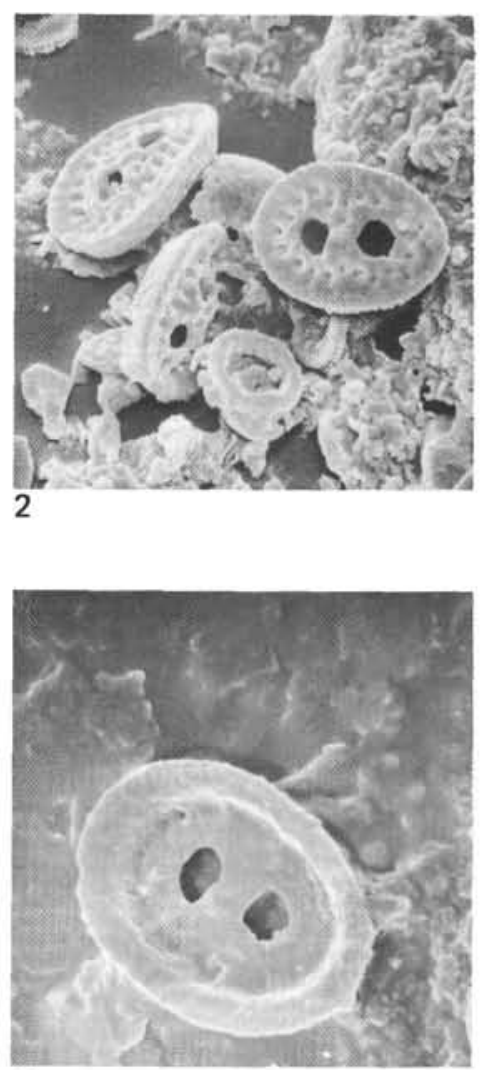

5

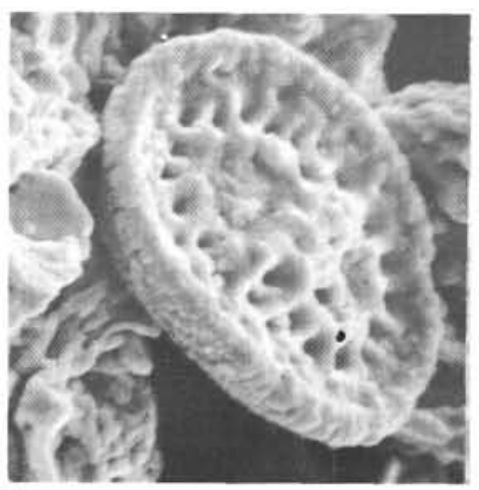

8

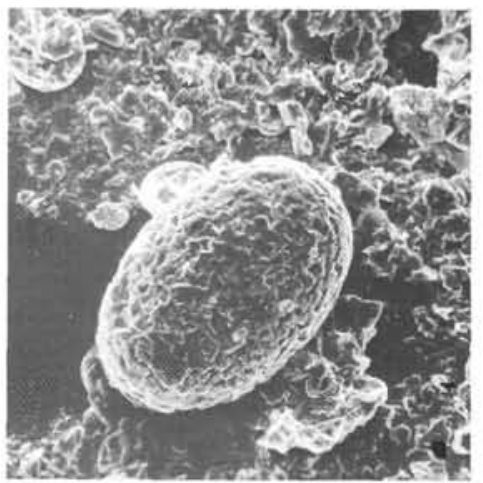

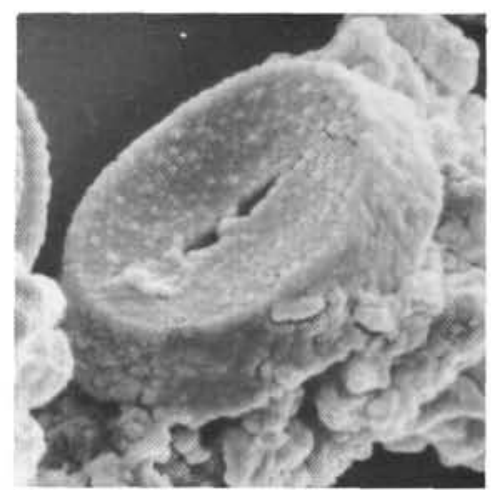

3

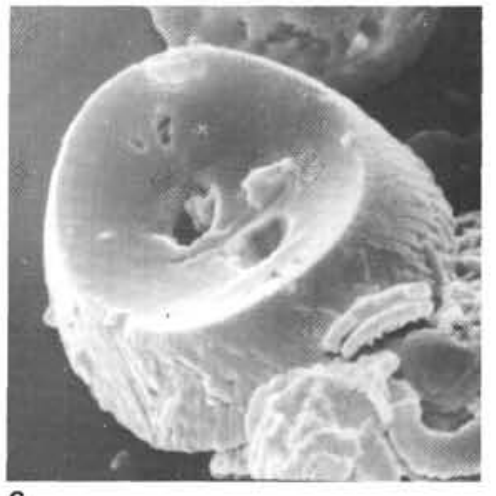

6

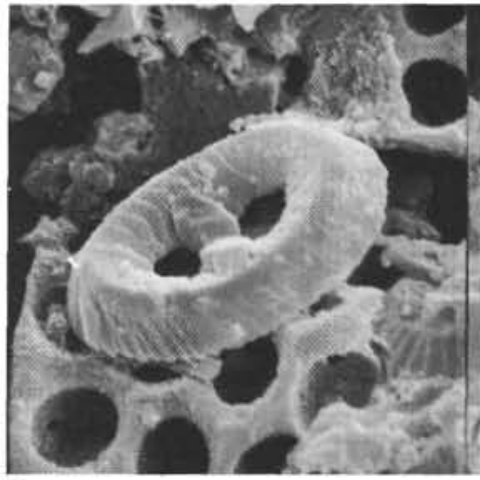

9

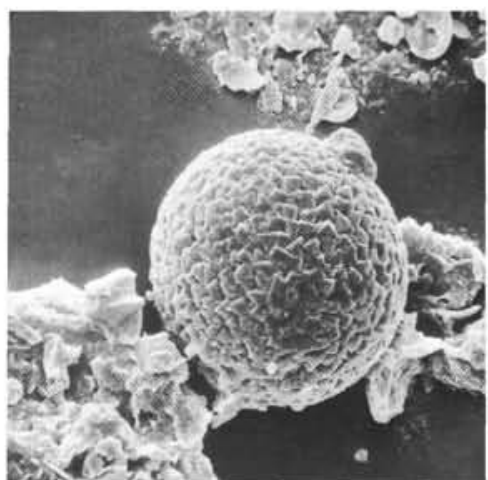

12 


\section{PLATE 6}

Figure $1 \quad$ Rhabdosphaera tenuis Bramlette and Sullivan, 1961. $2300 \times$

Sample 402A-5-1, 106-107 cm.

Figure 2 Rhabdosphaera spinula Levin, 1965. $2500 \times$.

Sample 405-14-1, 124-125 cm.

Figure 3 Blackites creber (Deflandre) Roth, 1970. $5000 \times$. proximal view. Sample 402A-5-1, 106-107 cm.

Figure 4 Naninfula deflandrei Perch-Nielsen, 1968. $5000 \times$ Sample 402A-3-4, 129-130 cm.

Figures 5, 6 Rhabdolithus solus Perch-Nielsen, 1971. Sample 401-14-1, 26-27 cm.

5. $2500 \times$.

6. $5000 \times$.

Figure 7 Blackites cf. B. creber (Deflandre) Roth, 1970. $5000 \times$.

Sample 402A-3-4, 129-130 cm.

Figure $8 \quad$ Blackites creber (Deflandre) Roth, 1970. $5000 \times$

Sample 404-8-2, 23-24 cm.

Figure 9 Rhabdosphaera inflata Bramlette and Sullivan, 1961. $3300 \times$

Sample 405-9-2, 114-115 cm.

Figure $10 \quad$ Blackites cf. B. creber (Deflandre) Roth, 1970. $4500 \times$

Sample 402A-5-1, 106-107 cm.

Figure $11 \quad$ Rhabdolith gen. indet. sp. indet. $5000 \times$.

Sample 404-8-2, 23-24 cm.

Figure $12 \quad$ Rhabdolith gen. indet.

$3500 \times$.

Sample 404-8-2, 23-24 cm. 
PLATE 6

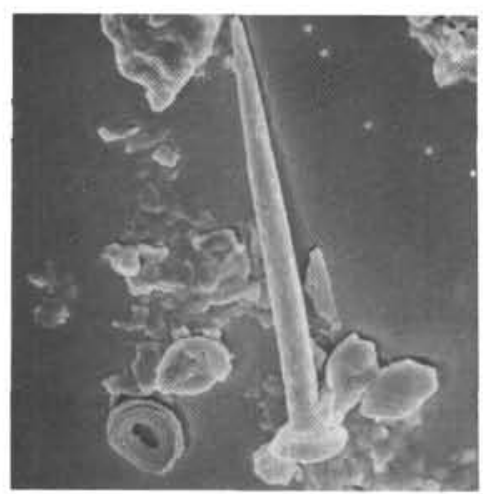

1

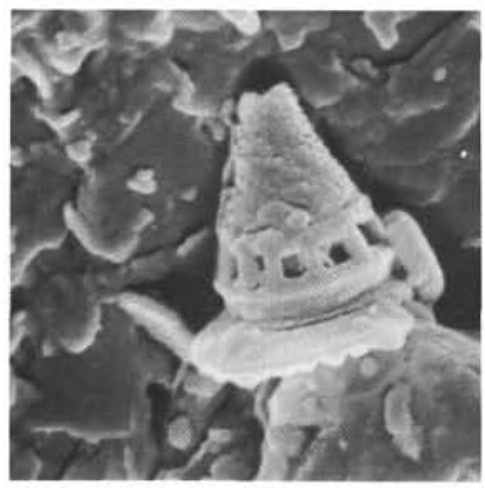

4

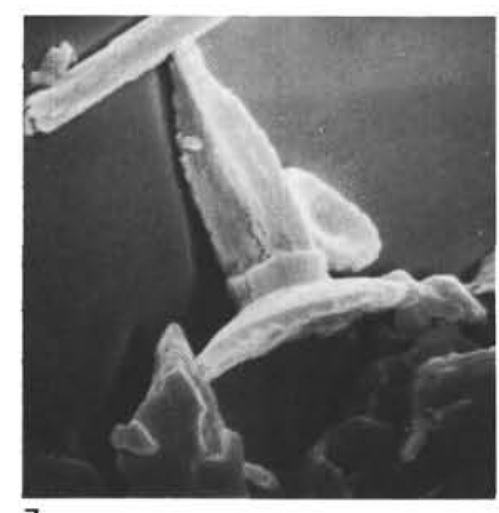

7

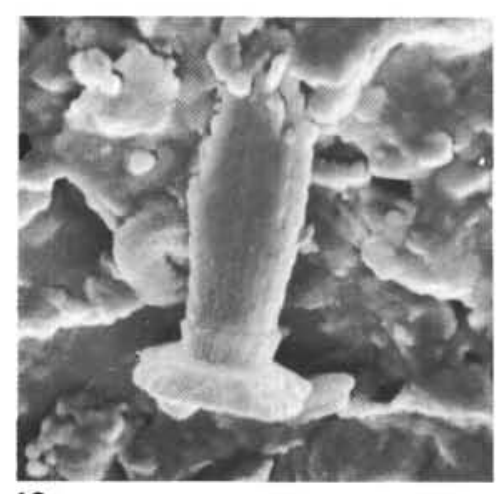

10
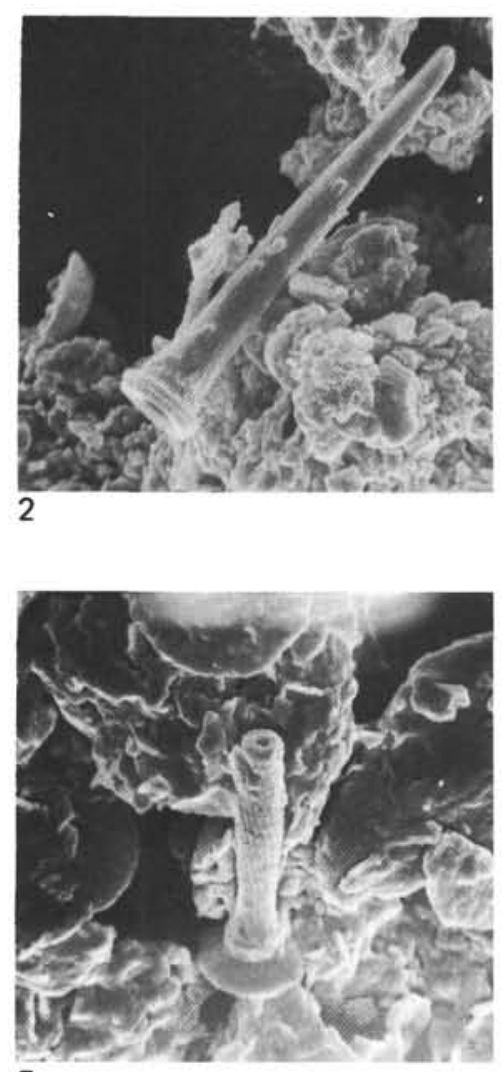

5

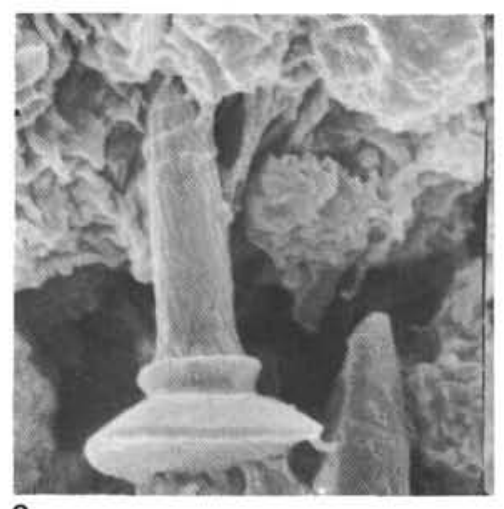

8

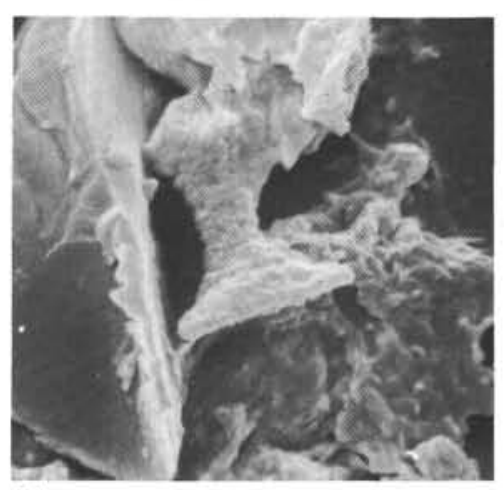

11

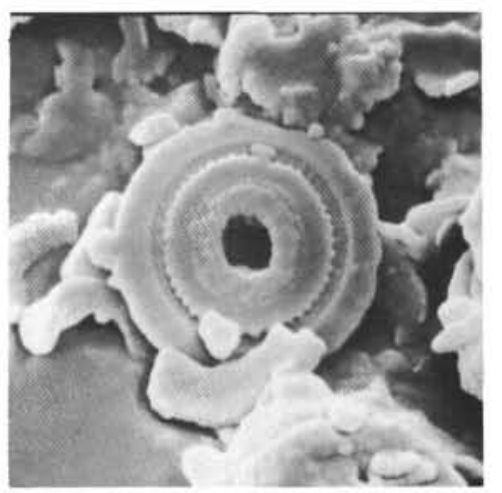

3

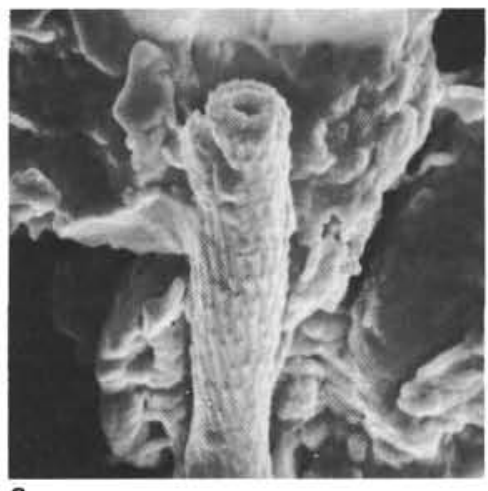

6
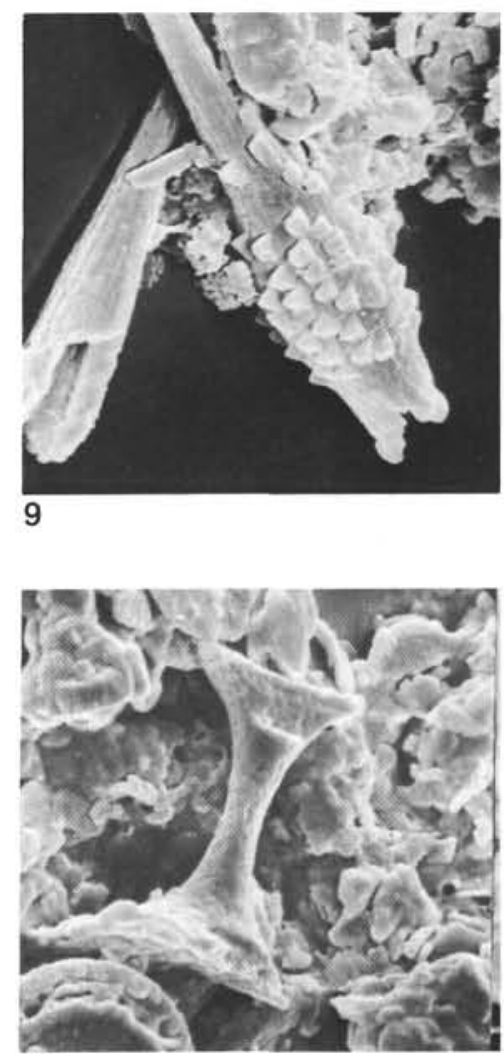

12 


\section{PLATE 7}

Figures 1, 2 Reticulofenestra umbilica (Levin) Martini and Ritzkowski, 1968. Sample 405-25-1, 58-59 cm.

$2500 \times$.

1. Distal view.

2. Proximal view.

Figures 3, 4 Cribrocentrum reticulatum (Gartner and Smith) Perch-Nielsen, 1971. Sample 402A-3-4, 129-130 cm. $5000 \times$.

3. Distal view.

4. Proximal view.

Figure 5 Coccolithus pelagicus (Wallich) Schiller, 1930. $4000 \times$, distal view.

Sample 406-2-3, 8-9 cm.

Figure 6 Ericsonia fenestrata (Deflandre) Stradner, 1968.

$5000 \times$, distal view.

Sample 405-14-2, 36-37 cm.

Figure 7 Cyclococcolithus formosus Kamptner, 1963.

$4200 \times$, distal view.

Sample 402A-5-2, 9-10 cm.

Figure $8 \quad$ Cyclolithella aprica Roth, 1973.

$4500 \times$, distal view.

Sample 402A-5-1, 106-107 cm.

Figure 9 Cyclolithella pakistanica Haq, 1971.

$5000 \times$, distal view.

Sample 402A-3-4, 129-130 cm.

Figure $10 \quad$ Cyclococcolithus sp.

$3250 \times$, distal view.

Sample 405-14-2, 36-37 cm.

Figure $11 \quad$ Cyclolithus bramlettei Hay and Towe, 1962.

$5000 \times$, proximal view.

Sample 401-14-1, 26-27 cm.

Figure 12 Cyclococcolithina kingi Roth, 1970.

$5000 \times$, distal view.

Sample 405-14-2, 36-37 cm. 
PLATE 7

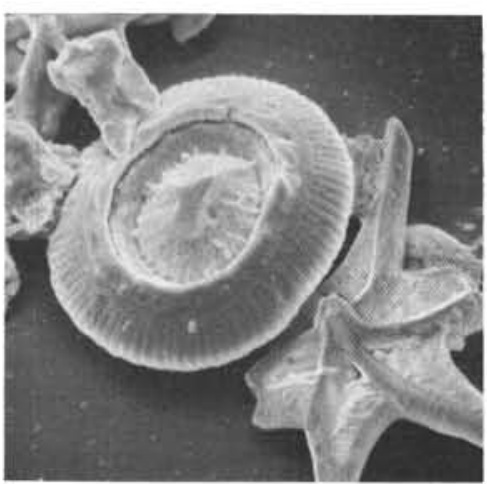

1

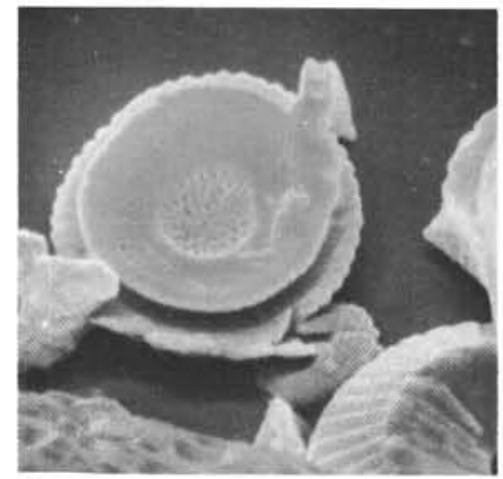

4

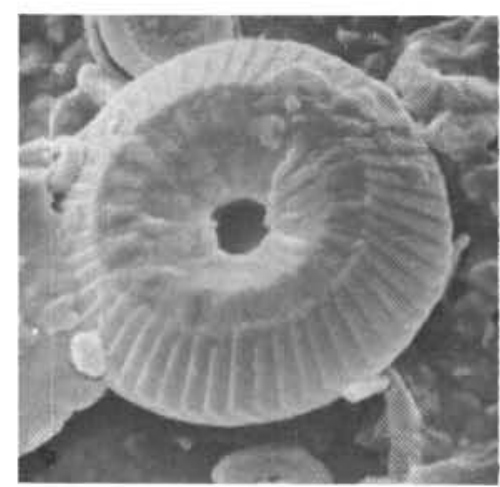

7

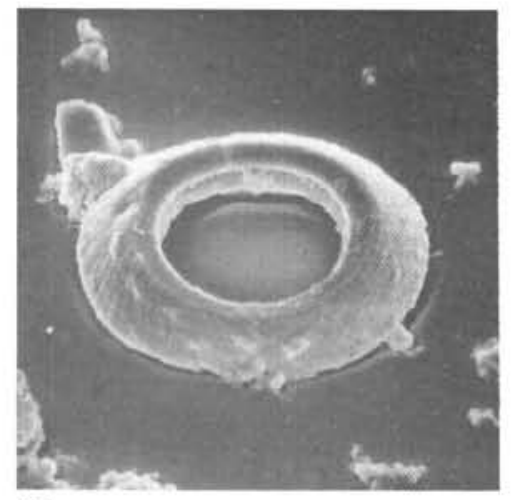

10

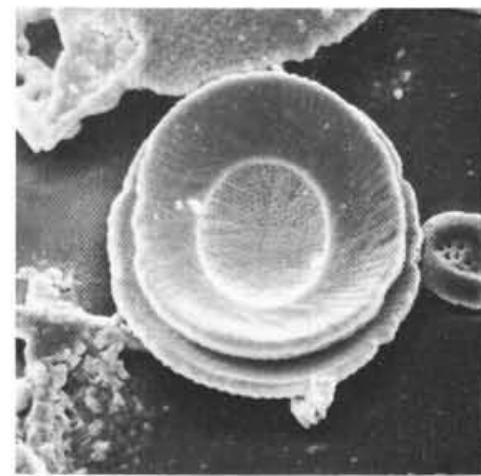

2

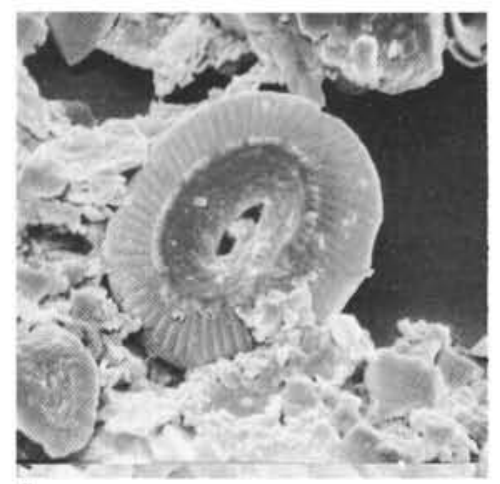

5

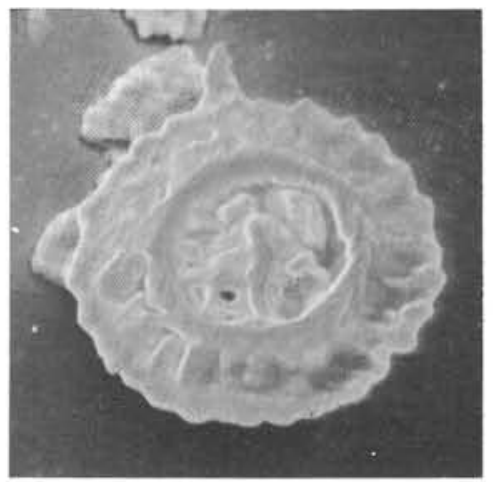

8

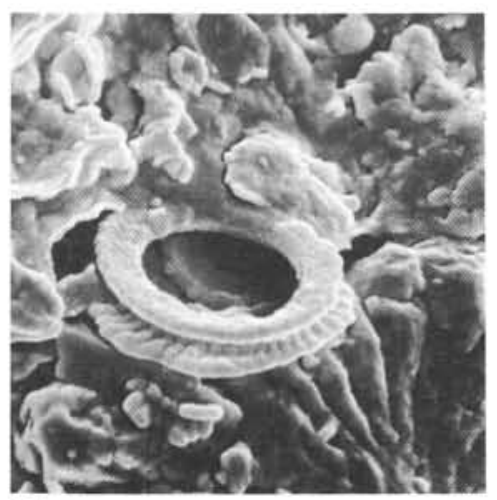

11

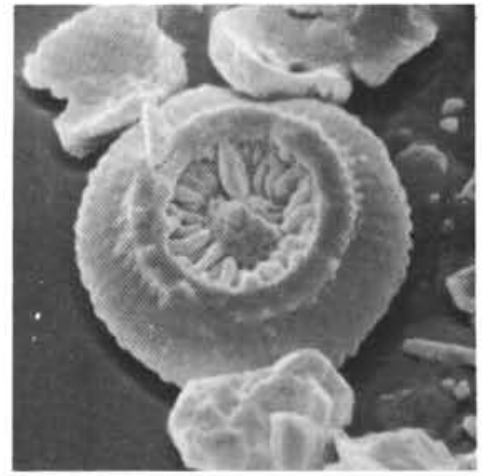

3
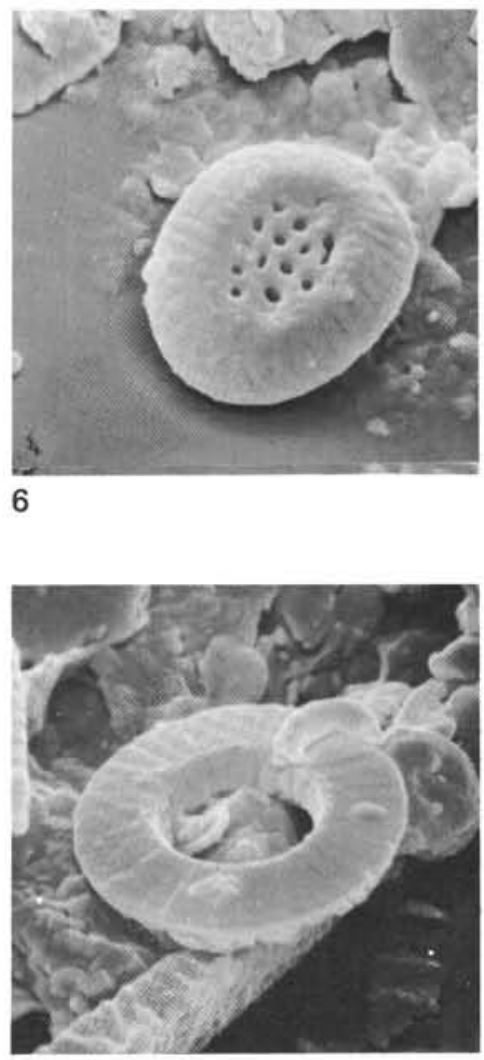

9

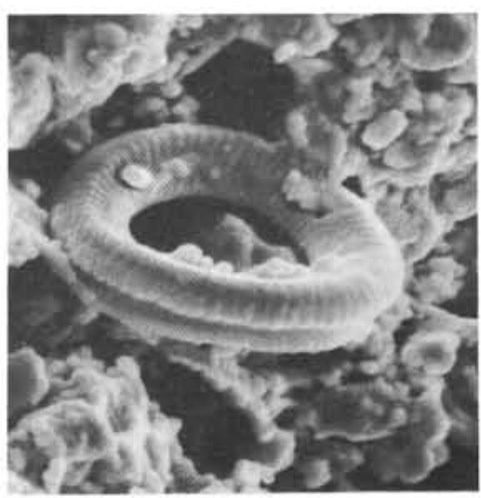

12 
PLATE 8

Figures 1-3 Nannoturba spinosa nov. gen. n. sp.

Holotype: Figure 3, SM.B 13019

$3200 \times$.

Sample 404-7-1, 13-14 cm.

Figures 4-6 Nannoturba robusta nov. gen. n. sp.

Holotype: Figure 4, SM.B. 13017

$4000 \times$.

Sample 404-7-1, 13-14 cm.

Figure 7

Helicosphaera seminulum Bramlette and Sullivan, 1961.

$3500 \times$, proximal view.

Sample 405-14-1, 1.24-125 cm.

Figure 8

Helicosphaera dinesenii (Perch-Nielsen) Jafar and Martini, 1975.

$3250 \times$, proximal view.

Sample 405-9-2, 24-25 cm.

Figure 9 Pontosphaera sp.

$3250 \times$, distal view.

Sample 405-14-1, 124-125 cm.

Figures 10-12 Scyphosphaera sp. Sample 405-14-1, 124-125 cm.

10. Distal view.

11, 12. Side view. 
PLATE 8

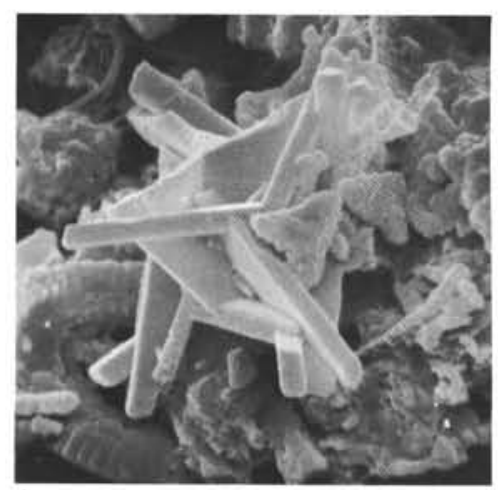

1

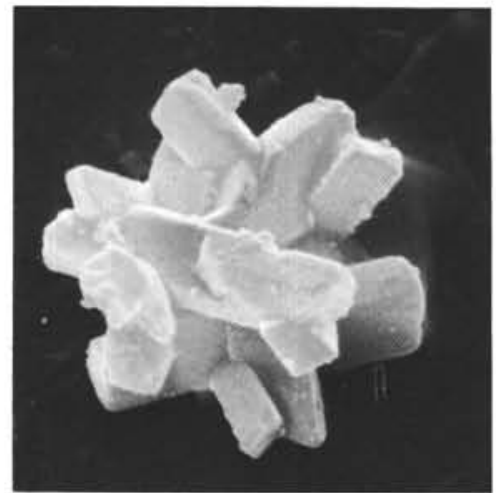

4
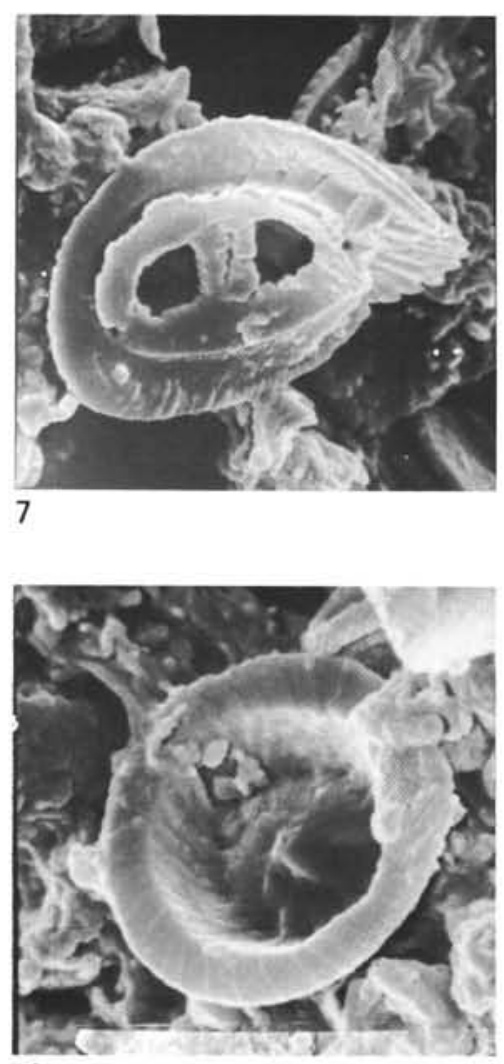

10
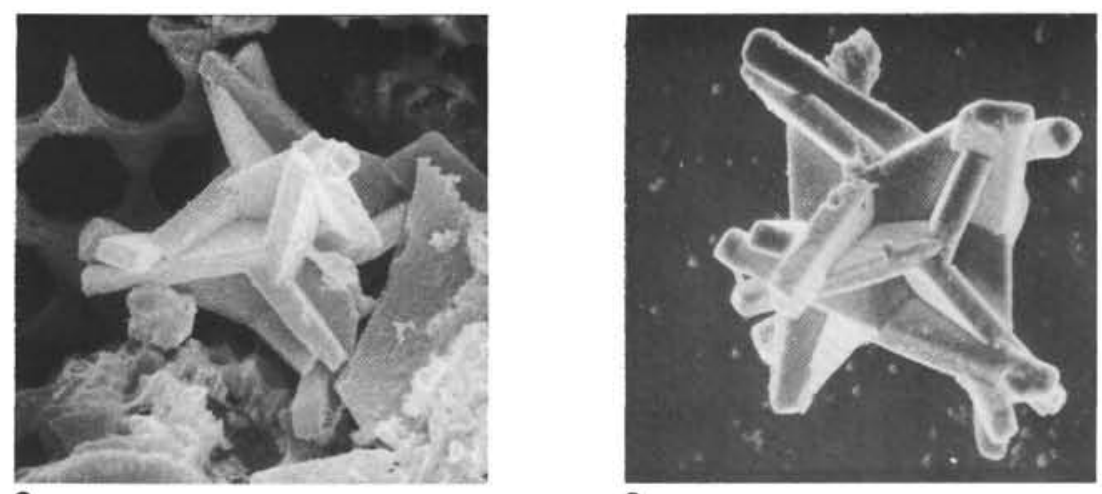

3

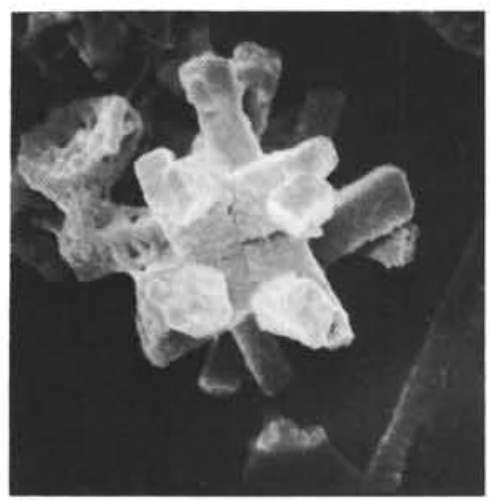

5

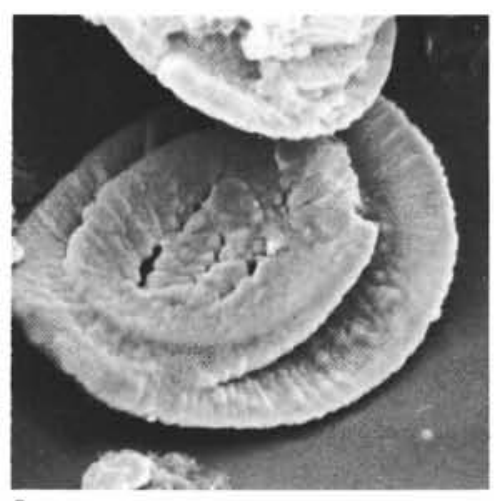

\section{8}

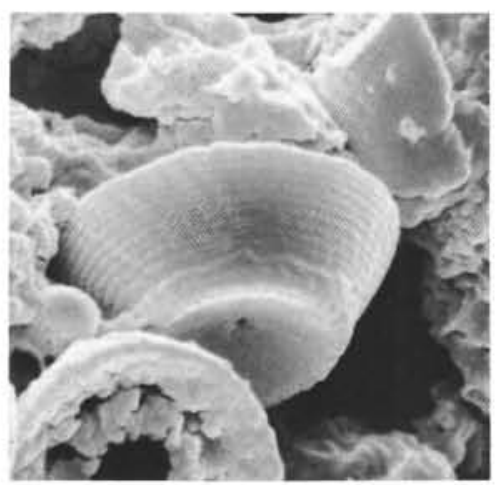

11

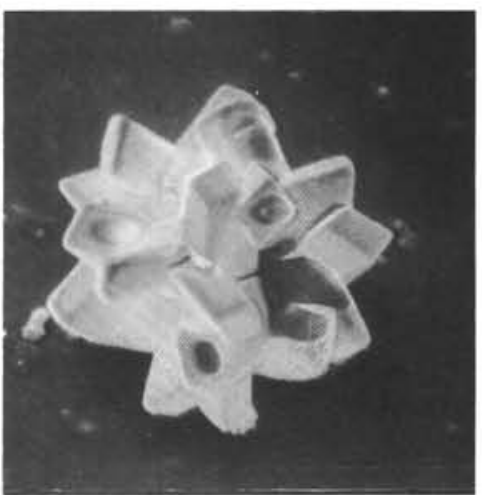

6
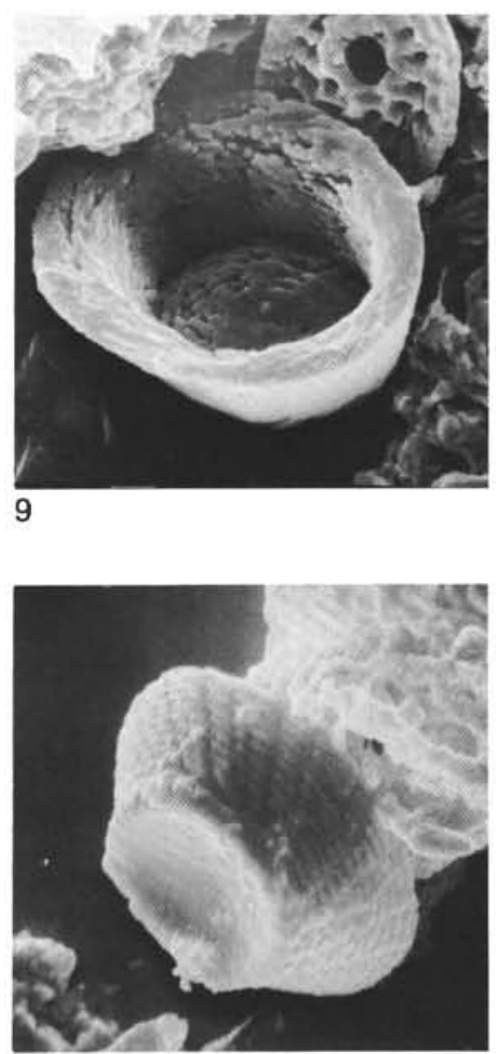

12 


\section{PLATE 9}

Figure $1 \quad$ Discoaster lenticularis Bramlette and Sullivan, 1961. $6500 \times$. Sample 405-14-1, 124-125 cm.

Figure 2 Discoasteroides kuepperi (Stradner) Bramlette and Sullivan, 1961. $4400 \times$. Sample 405-14-1, 124-125 cm.

Figure 3 Conococcolithus minutus Hay and Mohler, 1967. $5000 \times$. Sample 401-14-3, 64-66 cm.

Figure 4 Rhabdosphaera vitrea (Deflandre) Bramlette and Sullivan, 1961. $4800 \times$. Sample 402 A-5-1, 24-25 cm.

Figures 5,9,10 Pontosphaera pacifica Burns, 1973. Sample 406-2-3, 111-113 cm.

5. $1900 \times$, proximal view.

9. $2000 \times$, proximal view.

10. $2000 \times$, distal view.

Figure $6 \quad$ Koczyia wechesensis (Bukry and Percival) Sherwood, 1974. $3000 \times$. Sample 405-14-1, 124-125 cm.

Figure $7 \quad$ Ellipsolithus macellus (Bramlette and Sullivan) Sullivan, 1964. $2200 \times$, distal view. Sample 401-14-3, 64-65 cm.

Figure $8 \quad$ Thoracosphaera operculata Bramlette and Martini, 1964. $800 \times$. Sample 401-14-1, 26-27 cm.

Figures 11, 12 Helicosphaera carteri (Wallich) Kamptner, 1954. Sample 406-2-3, 111-113 cm.

11. $2000 \times$, distal view.

12. $2000 \times$, proximal view.

Figure 13 Helicosphaera dinesenii (Perch-Nielsen) Jafar and Martini, 1975. $2800 \times$, proximal view. Sample 405-9-2, 24-25 cm.

Figure $14 \quad$ Helicosphaera seminulum Bramlette and Sullivan, 1961. $3400 \times$, distal view. Sample 405-14-2, 36-37 cm.

Figure $15 \quad$ Scyphosphaera $\mathrm{sp}$.

$5000 \times$. Sample 405-14-1, 124-125 cm.

Figure 16 Cyclococcolithus leptoporus (Murray and Blackman) Kamptner, 1954. $1300 \times$. Sample 403-3-3, 8-9 cm.

Figure 17 Umbilicosphaera mirabilis Lohmann, 1902. $3700 \times$, distal view. Sample 406-2-3, 111-113 cm.

Figure 18 Pseudoemiliania lacunosa (Kamptner) Gartner, 1969. $5000 \times$. Sample 406-2-3, 111-113 cm.

Figure 19 Gephyrocapsa ornata Heimdal, 1973. $6800 \times$. Sample 403-3-3, 8-9 cm.

Figure 20 Discolithina japonica Takayama, 1967. $5000 \times$, proximal view. Sample 406-2-3, 111-113 cm. 
PLATE 9
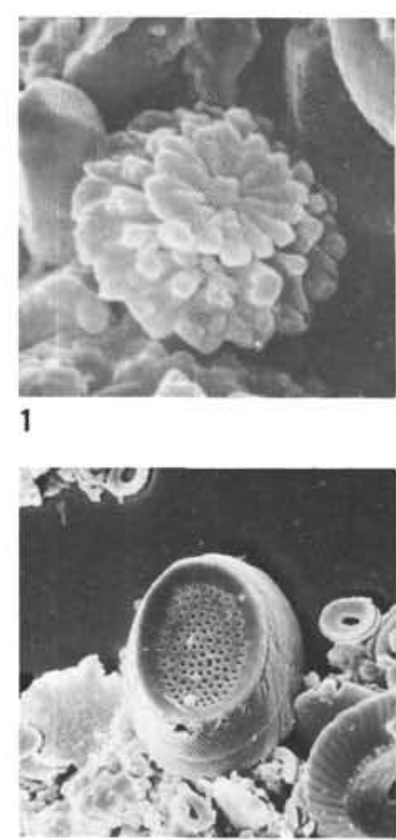

5

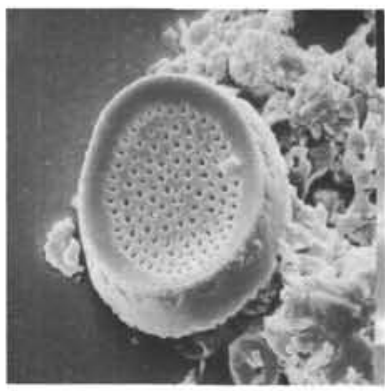

9

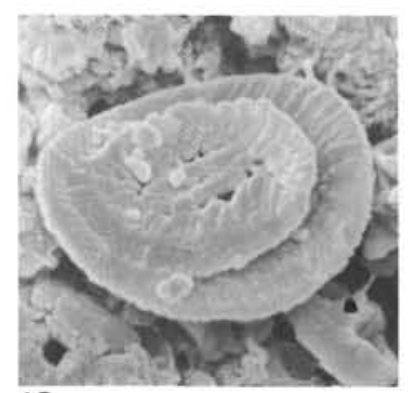

13

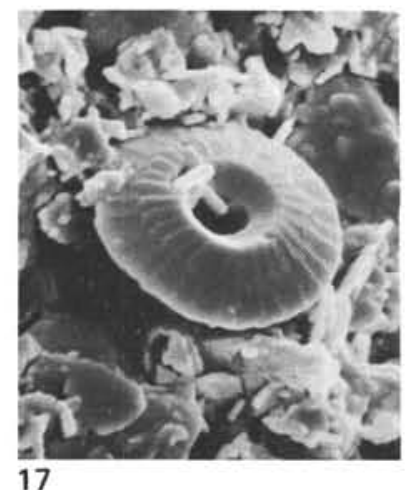

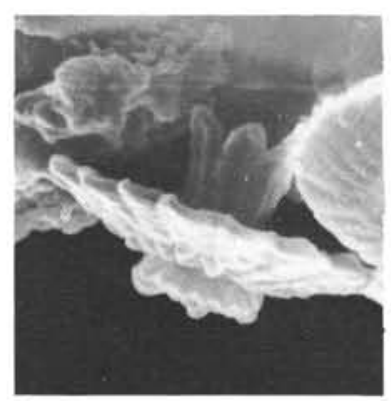

2
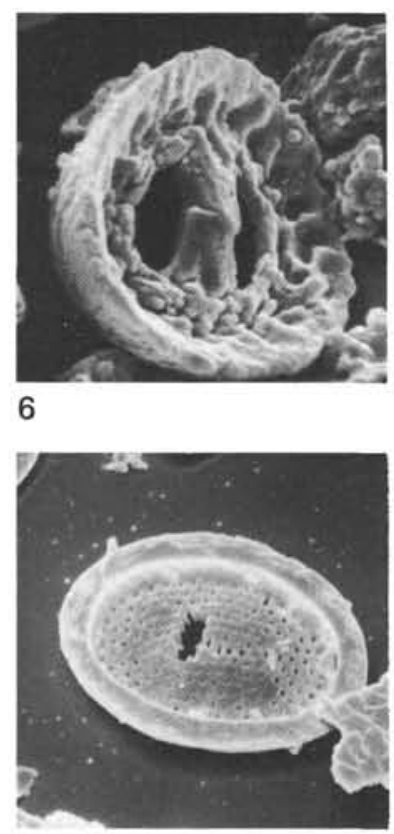

10
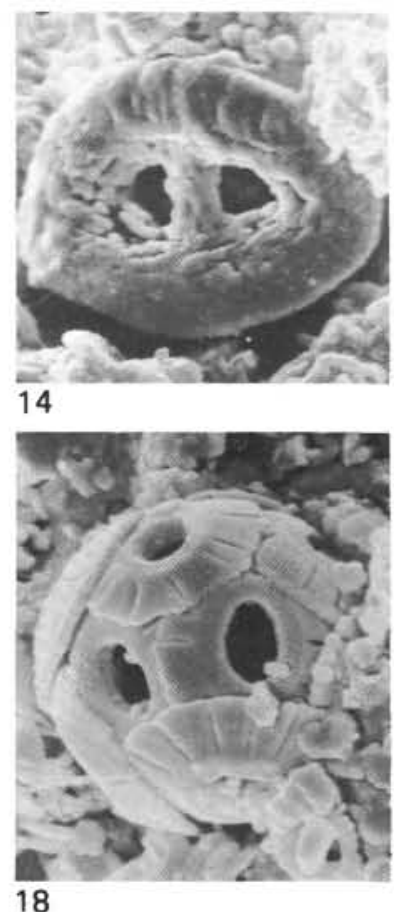

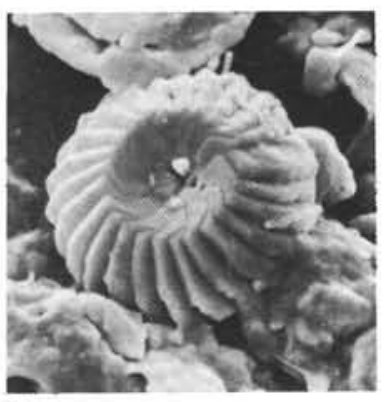

3

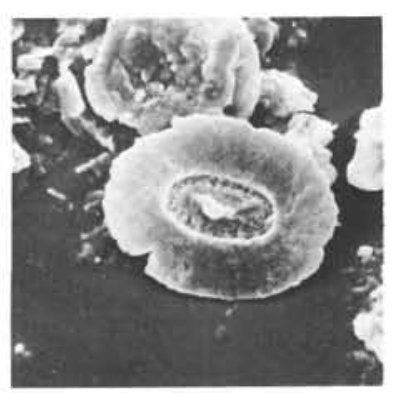

7

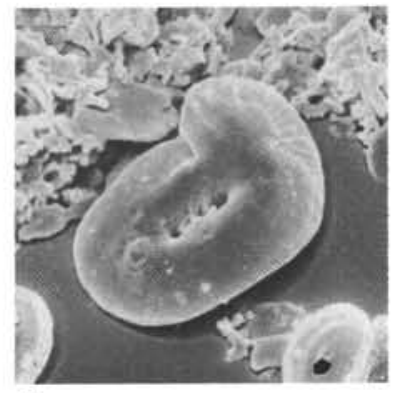

11

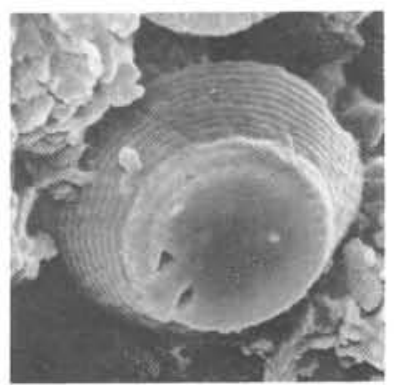

15

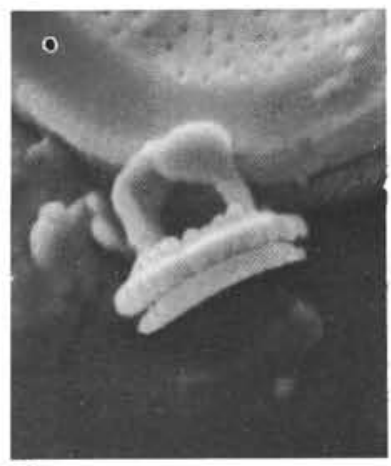

19

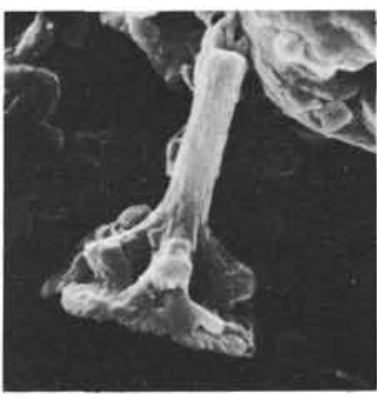

4

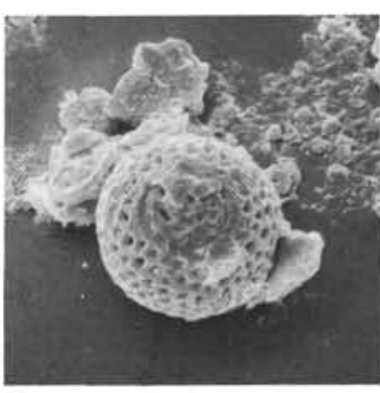

8

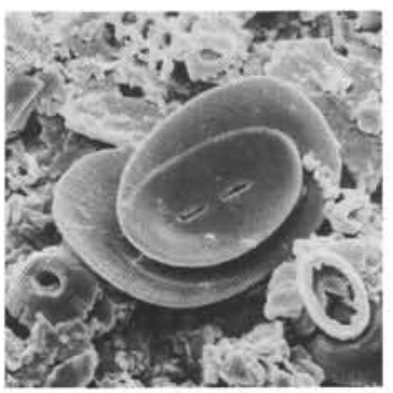

12
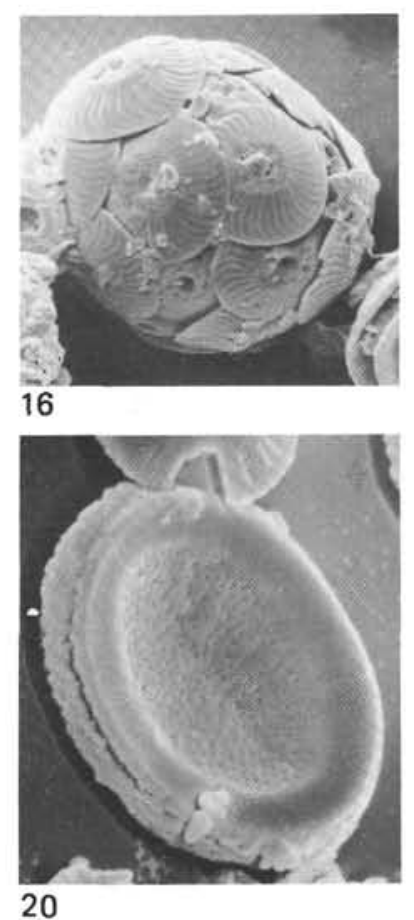